\title{
NIAGARA FALLS STORAGE SITE ENVIRONMENTAL REPORT FOR
}

CALENDAR YEAR 1989

MAY 1990

Prepared for

UNITED STATES DEPARTMENT OF ENERGY

OAK RIDGE OPERATIONS OFFICE

Under Cintract No. DE-AC05-810R20722

By

Bechtel National, Inc.

P.O. Box 350

Oak Ridge, Tennessee

Bechtel Job No. 14501 


\section{BUMMARY ABSEBBMENT \\ ENVIRONMENTAL COMPLIANCE ACTIVITY \\ D.8. DEPARTMENT OF ENERGY \\ BURPLUS FACILITIES MNNAGEMENT PROGRAM \\ NIAGARA FALLS BTORAGE BITE}

\section{BACKGROUND AND OVERVIET}

To evaluate the environmental compliance record of the Niagara Falls storage site (NFSS), managed as part of the surplus Facilities Management Program, it is necessary to describe the history of the site.

NFSS is a remnant of the original approximately 610-ha (1,500-acre) site that was used during World War II by the Manhattan Engineer District (MED) project and was a portion of the Department of the Army's Lake Ontario ordnance Works (LOOW). Except for nonradioactive boron-10 enriching operations during the periods 1954 to 1958 and 1964 to 1971, the site's major use from 1944 to the present has been for storage of radioactive residues produced as by-products of uranium production during the MED project and subsequent Atomic Energy Commission projects.

As a result of the storage and transshipment operations involving radioactive materials, some portions of the former Loow other than the present NFSS were also contaminated. In addition, some of the radioactive materials stored at NFSS over the years were subject to water and wind erosion. As a result, radioactive materials migrated off site, chiefly through the NFss drainage ditches.

NFSS covers 77 ha (191 acres) of the approximately 610 ha (1,500 acres) originally used for shipment, storage, and burial of radioactive materials and wastes. In 1979 and 1980, comprehensive: radiological characterization was conducted at NFSS. Radiological surveys of the vicinity properities were performed from 1981 to 1985 . 
Remedial action began in 1981 on the vicinity properties with the cleanup of a small piece of property adjacent to the site. Remedial action on the remaining vicinity properties was performed from 1983 through 1986. Remedial action at NFSS itself began in 1982 and continued through 1986. All contaminated materials remediated from 1981 to 1986 are stored in the interim waste containment facility (IWCF).

In 1988 , several isolated areas of residual radioactivity were excavated and the materials were placed in temporary storage. At present, all areas of residual radioactivity on site have been remediated, with the exception of one localized area suspected to be both radiologically and chemically contaminated.

The 4-ha (10-acre) IWCF is the dominant feature of NFSS. The IWCF is enclosed within a dike and cutoff wall, each constructed of compacted clay. The cutoff wall extends a minimum of $46 \mathrm{~cm}$ (18 in.) into the underlying gray clay unit. The dike and cutoff wall, in conjunction with the engineered earthen drainage cover or cap, enclose the wastes in a clay envelope that provides a barrier to migration of waste constituents.

During its history, NFSS has been subject to evolving federal and state environmental regulations. The following summary describes compliance requirements as they currently exist.

\section{Clean Air Act (CAA) and National Emission standards for Hazardous} Air Pollutants (NESHAPs)

NFSS does not have any state ur federal air permits. As a nonoperating facility, only subparts $H$ and $Q$ of NESHAPs are applicable. Compliance with the non-radon radionuclide standard in Subpart $H$ will be determined by evaluating the site using a computer model (e.g., AIRDOS-PC) approved by the Environmental Protection Agency (EPA). A strategy for determining compliance with the radon flux standard in subpart $Q$ was transmitted to EPA. 
Comments were received from EPA on the proposed compliance strategy on April 19, 1990. The comments require minor modifications to the compilance strategy. Radon flux measurements of the pile will begin by July 18, 1990, absent further comments from EPA.

\section{Department of Energy (DOE) Orders for Radionuclide Releases}

Site releases must comply with specific DOE orders that place quantitative limits, called derived concentration guides (DCGs), and dose limits for radiological releases from DOE facilities. Results of environmental monitoring conducted in 1.989 show that NFSS is in compliance with DOE orders.

\section{Clean Water Act (GWA)}

NFSS does not have any state or federal water permits and has only stormwater discharge. An environmental compliance assessment conducted by Oak Ridge lvational Laboratory (ORNL) in July 1989 did not find any deficiencies under the CWA. The amendments to the CWA in 1987 required EPA to promulgate regulations requiring permits for stormwater discharges from industrial facilities; therefore, a stormwater discharge permit may be required in the fut re.

\section{Resource Conservation and Recovery Act (RCRA)}

RCRA-regulated waste is not present at NFSS. Additionally, an environmental compliance assessment conducted by ORNL in october 1989 did not find any deficiencies under RCRA.

Comprehensive Environmental Response, Compensation, and Liability Act (CERCLA)

NFSS is not on the National Priorities List. Any remaining remediation of the site will be managed by DOE under the authority of CERCLA. 


\section{Toxic substances Control Act (TBCA)}

TSCA-regulated wastes, which were identified at NFSS during 1989, are no longer present. The environmental compliance assessment of the site by ORNL found four deficiencies under TSCA that involved improper storage of PCB-contaminated materials. The materials have been shipped to a permitted disposal facility.

\section{National Environmental Policy Act (NEPA)}

In the past, compliance with NEPA has been accomplished through the use of action description memoranda and corresponding memoranda-to-file and an environmental impact statement (EIS) and corresponding record of decision (ROD). Removal actions at the vicinity properties have been handled with action description memoranda and corresponding memoranda-to-file and have been determined to have had no significant impact on the environment. The EIS and ROD were issued in 1986 to state the decision on the long-term disposition of NFSS. For the radioactive wastes, DOE has selected long-term, in-place management consistent with EPA regulations governing uranium mill tailings. 


\section{ABSTRACT}

The environmental monitoring program, which began in 1981, was continued during 1989 at the Niagara Falls storage site (NFSS), a United States Department of Energy (DOE) surplus facility located in Niagara county, New York, that is currently used for interim storage of radioactive residues, contaminated soils, and rubble. The monitoring program is being conducted by Bechtel National, Inc.

The monitoring program at NFSS measures radon concentrations in air; external gamma radiation levels; and uranium and radium concentrations in surface water, groundwater, and sediment. Additionally, several nonradiological parameters are measured in groundwater. To verify that the site is in compliance with the DOE radiation protection standard and to assess its potential effect on public health, the radiation dose was calculated for a hypothetical maximally exposed individual. Based on the conservative scenario described in this report, this hypothetical individual receives an annual external exposure equivalent to approximately 2 percent of the DOE radiation protection standard of $100 \mathrm{mrem} / \mathrm{yr}$. This exposure is less than a person receives during a one-way flight from New York to Los Angeles (because of the greater amounts of cosmic radiation at higher altitudes).

The cumulative dose to the population within an $80-\mathrm{km}$ (50-mi) radius of NFSS that results from radioactive materials present at the site is indistinguishable from the dose that the same population receives from naturally occurring radioactive sources.

Results of the 198 monitoring show that NFSS is in compliance with applicable DOE radiation protection standards. 


\section{CONTENTS}

Page

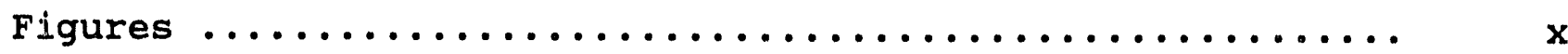

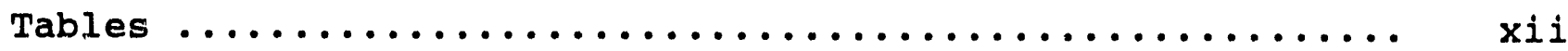

1.0 INTRODUCTION $\ldots \ldots \ldots \ldots \ldots \ldots \ldots \ldots \ldots \ldots \ldots \ldots \ldots \ldots \ldots \ldots \ldots \ldots \ldots \ldots$

1.I LOCATION AND DESCRIPTION $\ldots \ldots \ldots \ldots \ldots \ldots \ldots \ldots \ldots \ldots \ldots$

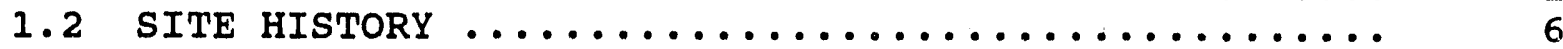

1.3 HYDROGEOLOGICAL CHARACTERISTICS OF THE SITE ...... 14

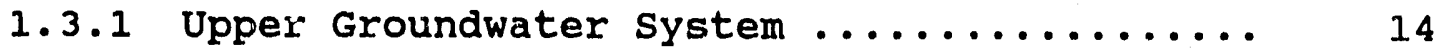

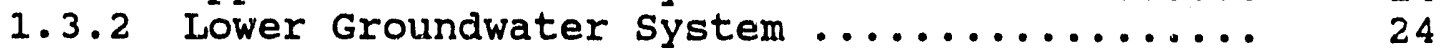

1.3.3 Bedrock Groundwater system ............. 35

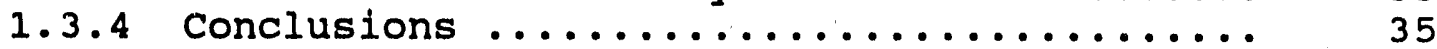

2.0 SUMMARY OF MONITORING RESULTS $\ldots \ldots \ldots \ldots \ldots \ldots \ldots \ldots \ldots \ldots$

3.0 DATA COLLECtion, ANALYSis, AND EVALUATION .......... 40

3.1 RADON MONITORING ...................... 41

3.2 EXTERNAL GAMMA RADIATION $\ldots \ldots \ldots \ldots \ldots \ldots \ldots \ldots \ldots \ldots \ldots$

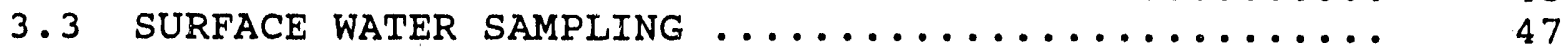

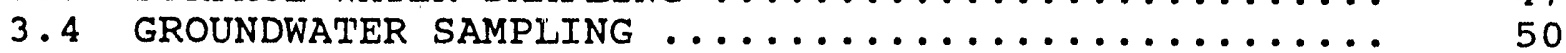

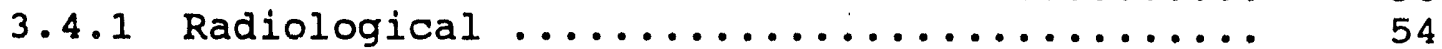

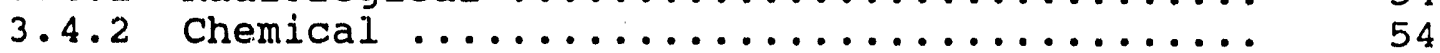

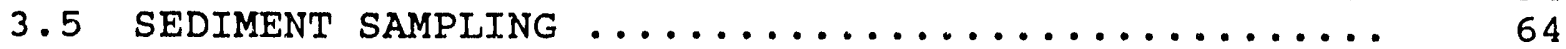

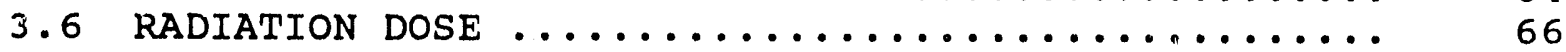

3.6.1 Dose to the Maximally Exposed Individual .. 67

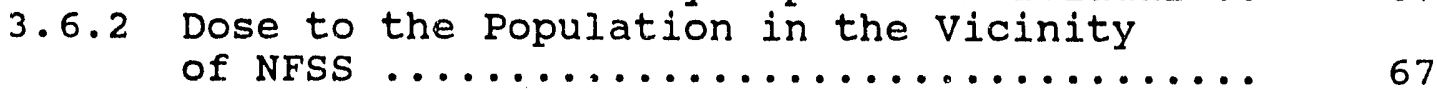

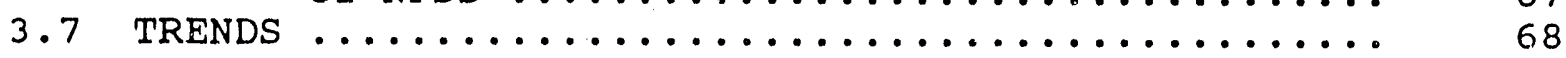

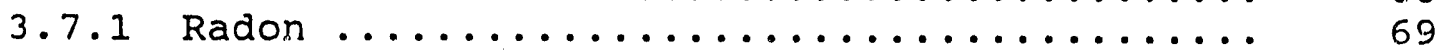

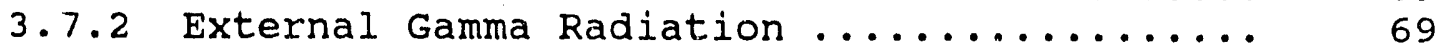

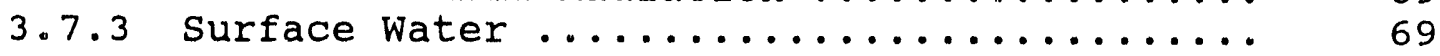

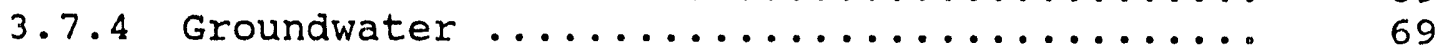

4.0 RELATED ACTIVITIES AND SPECIAL STUDIES ........... 78

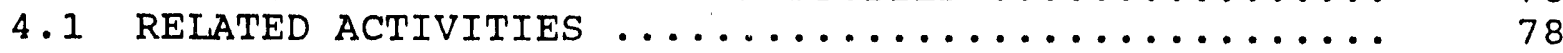

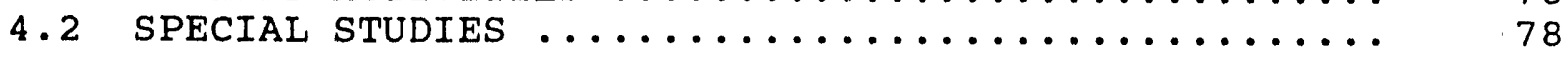

REFERENCES $\ldots \ldots \ldots \ldots \ldots \ldots \ldots \ldots \ldots \ldots \ldots \ldots \ldots \ldots \ldots \ldots \ldots \ldots \ldots \ldots$

APPENDIX A: Quality Assurance .................... A-1

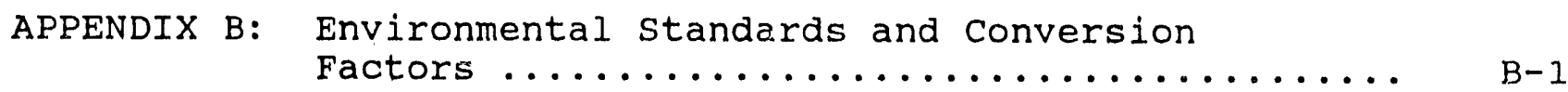

APPENDIX $\mathrm{c}$ : Abbreviations and Acronyms .................. $\mathrm{C}-1$

APPENDIX D: Radiation in the Environment ............. D-1 
Page

APPENDIX E: Sample Well Construction logs .............. E-1

APPENDIX F: Distribution List for Niagara Falls Storage

Site Environmental Report for Calendar

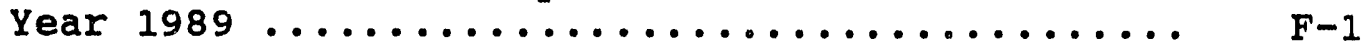


FIGURES

Figure

$1-1$

$1-2$

$1-3$

$1-4$

$1-5$

$1-6$

1-7

$1-8$

$1-9$

$1-10$

$1-11$

$1-12$

$1-13$

$1-14$

$1-15$

$1-16$

$1-17$
Title

Page

Location of NFss $\ldots \ldots \ldots \ldots \ldots \ldots \ldots \ldots \ldots \ldots \ldots \ldots \ldots$

2

Aerial View of the NFSS Interim Waste containment Facility (IVCF) 0.0 .0 .000 .0 .00 .0 .0 .0 .0

Present Configuration of NFSS $\ldots \ldots \ldots$

4

7

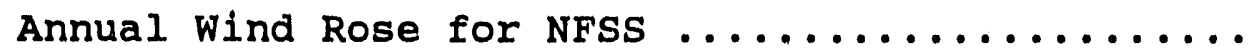

Generalized Land Use in the Vicinity of NFSS ....

8

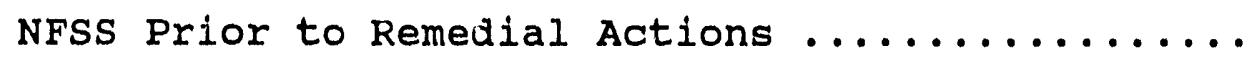

10

Locations of Groundwater Monitoring Wells

at NFSS

Hydrographs of Upper Groundwater system

Wells $O W-1 B$, $O W-2 B$, OW-3B, and $O W-4 B \ldots . . . .$. Hydrographs of Upper Groundwater system

Wells $O W-5 B$, OW-6B, $O W-7 B$, and $O W-8 B \ldots . . . .$.

20

Hydrographs of Upper Groundwater System

Wells $O W-10 B$, OW-11B, OW-12B, and OW-9B

Hydrographs of Upper Groundwater system

Wells $O W-13 B$, OW-14B, OW-15B, and $O W-16 B$

Hydrographs of Upper Groundwater Systam

Wells $O W-17 B$ and $O W-18 B \ldots \ldots \ldots \ldots$

Hydrographs of Lower Groundwater system

Wells $O W-1 A$, $O W-2 A$, $O W-3 A$, and $O W-4 A \ldots \ldots$

Hydrographs of Lower Groundwater system

Wells $O W-5 A$, $O W-6 A$, $O W-7 A$, and $O W-8 A \ldots . . .$.

Hydrographs of Lower Groundwater system

Wells $O W-10 A$, OW-11A, OW-12A, and OW-9A .......

Hydrographs of Lower Groundwater system

Wells $O W-13 A$, OW-14A, OW-15A, and OW-16A ......

Hydrographs of Lower Groundwater system

Wells $O W-17 A$ and $O W-18 A \ldots \ldots \ldots \ldots$ 
FIGUREB

(continued)

Eigure

$1-18$

$1-19$

$1-20$

$1-21$

$1-22$

$1-23$

$3-1$

$3-2$

$3-3$

\section{Title}

Page

Hydrographs of Lower Groundwater system Wells $\mathrm{BH}-49, \mathrm{BH}-59, \mathrm{BH}-64$, and $\mathrm{BH}-70 \ldots \ldots \ldots \ldots$

Hydrographs of Lower Groundwater system Wells

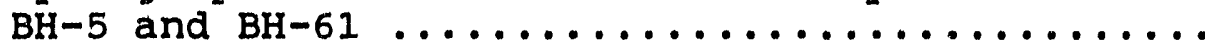

Comparison Hydrographs for Wells

OW-11A, $O W-7 A$, and $B H-64 \ldots \ldots \ldots \ldots \ldots$

Potentiometric Map of Lower Groundwater System $(7 / 5 / 89)$

Potentiometric Map of Lower Groundwater system $(11 / 1 / 89)$

Hydrographs of Bedrock Groundwater system

Wells $A-23 A$ and $A-49 \ldots \ldots \ldots \ldots \ldots \ldots \ldots$

Radon and External Gamma Radiation Monitoring Locations at NFSS

on-site Surface water and sediment Sampling Locations at NFSS

Off-Site surface Water and sediment sampling Locations in the Vicinity of NFSS ........... 
TABLES

Table

$1-1$

1-2

$1-3$

$3-1$

$3-2$

$3-3$

$3-4$

$3-6$

$3-7$

$3-8$

$3-10$

$3-11$

$3-12$

$3-13$
Iitle

Page

Residues and Middlesex Sands stored at NFSS .....

NFSS Upper System Monitoring Well Construction

Summary ..........................

NFSS Monitoring Well Construction summary for

Lower and Bedrock Groundwater systems .........

Concentrations of Radon-222 Measured by Terradex

Monitors at the NFss Boundary, 1989 ..........

44

External Gamma Radiation Levels at NFSS, 1989 ...

46

Concentrations of Tota? Uranium in NFSS Water

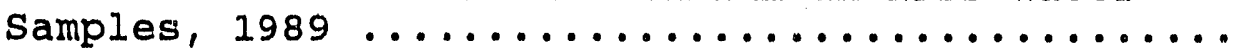

51

Concentrations of Radiun-226 in NFSS Water

Samples, 1989

52

55

Concentrations of Total Uranium in NFSS IWCF

Monitoring Wells, 1989 ..................

56

Concentrations of Radium-226 in NFSS IWCF

Monitoring Wells, 1989 ..................

Ranges of water quality Parameters in Gioundwater

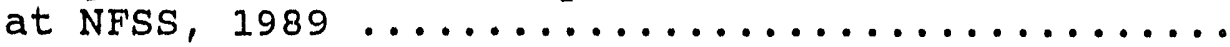

58

Ranges of Concentrations of Metal Ions Detected in Groundwater at NFSS, $1989 \ldots \ldots \ldots \ldots \ldots \ldots \ldots \ldots$

60

Total Uranium and Radium-226 Concentrations

in NFSS sediment Samples, $1989 \ldots \ldots \ldots \ldots \ldots \ldots \ldots$

65

Annual Average Concentrations of Radon-222

Measured at NFSS Boundary, 1985-1989 ..........

Annual Average External Gamma Radiation Levels

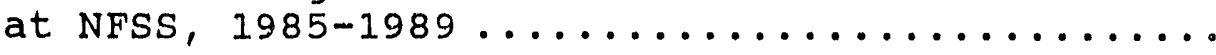

Annual Average Soncentrations of Total Uranium in NFSS Water samples, 1985-1989 ............

Annual. Average Concentrations of Radium-226 in NFSS Water Samples, 1985-1989 
TABLEB

(continued)

Table

Title

Page

$3-14$

Annual Average Concentrations $O \mathcal{F}$ Total Uranjum in NFSS Contairment Monitoring Wells, 1987-1989.

$3-15$

Annual Average Concentrations of Radium-226

in NFSS Containment Monitoring Wells, 1987-1989.

$A-1$

Summary Comparison of Water Sample Results

(EPA and TMA/E)

A-3

B-I

Conversion Factor

B-2 


\subsection{INIRODUCTION}

Environmental monitoring has been conducted at the Niagara Falls storage site (NFSS) since 1981. This report presents the findings of the environmental monitoring program conducted at the NFSS during calendar year 1989. NFSS is part of the United states Department of Energy (DOE) Surplus Facilities Management program.

\subsection{LOCATION AND DESCRIPTION}

NFSS occupies approximately 77 ha (190 acres) located in northwestern New York within thr Township of Lewiston (Niagara county). The site is approximately $6 \mathrm{~km}(4 \mathrm{mi})$ south of Lake ontario, $16 \mathrm{~km}$ (10 $\mathrm{mi}$ ) north of the City of Niagara Falls, and is in a generally rural setting. NFSS and its regional setting are shown in Figure 1-1; Figure $1-2$ is an aerial pinotograph of the site that highlights the interim waste containment facility (IWCF).

NFSS was developed as an interim waste storage area for radioactive residues from pitchblende processing and radium-contaminated sand, soil, and building rubble. Work on the IWCF was completed in late 1986.

The dominant feature of NFSS as presented in Figure 1-3 is the 4-ha (10-acre) IWCF, which is enclosed within a dike and cutoff wall, each constructed of compacted clay. The cutoff wall extends a minimum of $45.7 \mathrm{~cm}$ (18 in.) into an underlying gray clay unit. The dike and cutoff wall, in conjunction with the engineered earthen drainage cover or cap, enclose the wastes in a clay envelope that provides a barrier to migration of waste constituents. More detailed information on the design of IWCF is provided in Ref. 1.

The site is generally level but slopes gently to the northwest at elevations between 96.9 and $97.8 \mathrm{~m} \mathrm{(318} \mathrm{and} 321 \mathrm{ft}$ ) above mean sea level (msl). The site drains poorly because of soil characteristics and the flatness of the terrain. Soils at NFSS are predominantly silt loams underlain by a clayey glacial till and a 


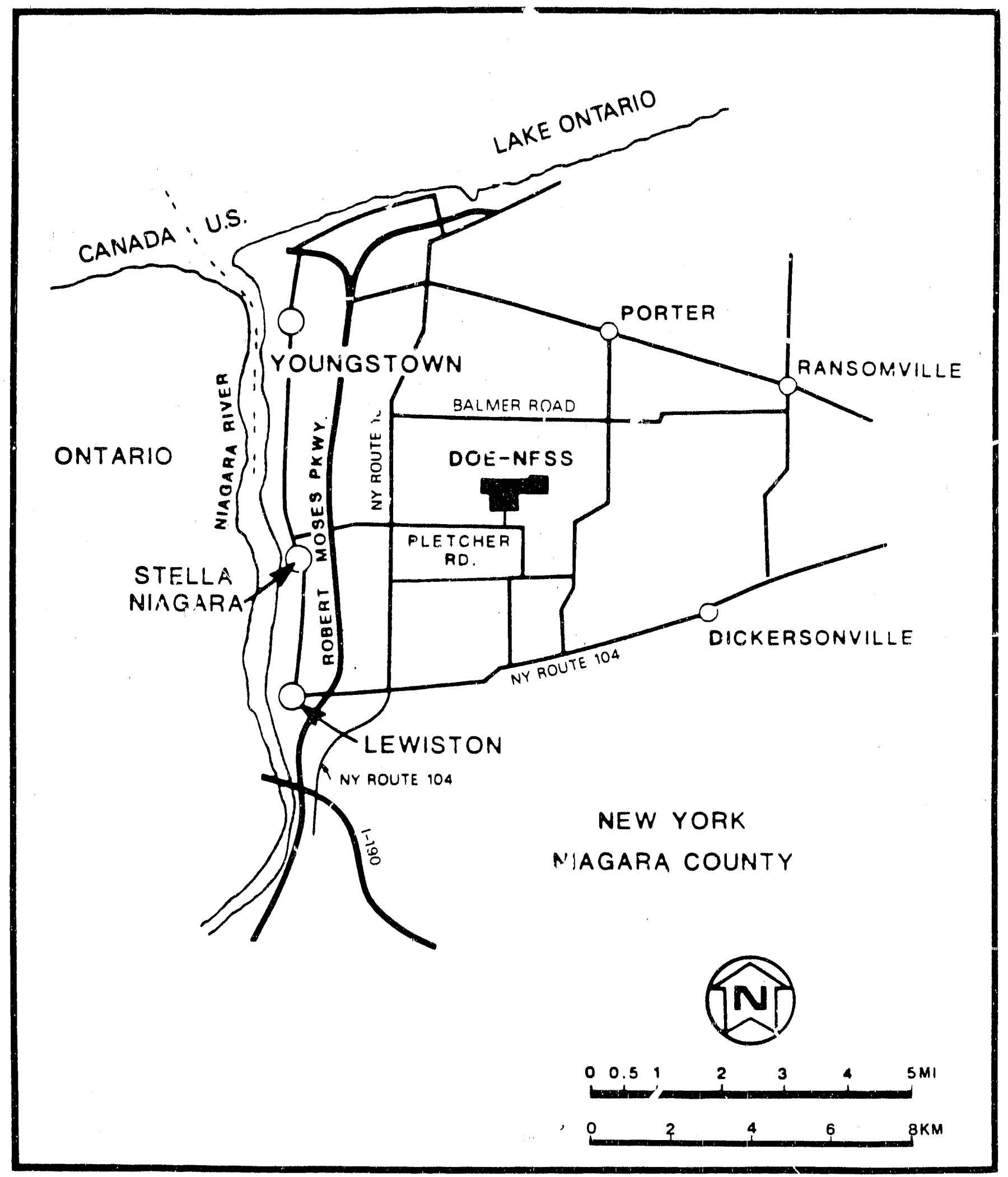

FIGURE 1-1 LOCATION OF NFSS 


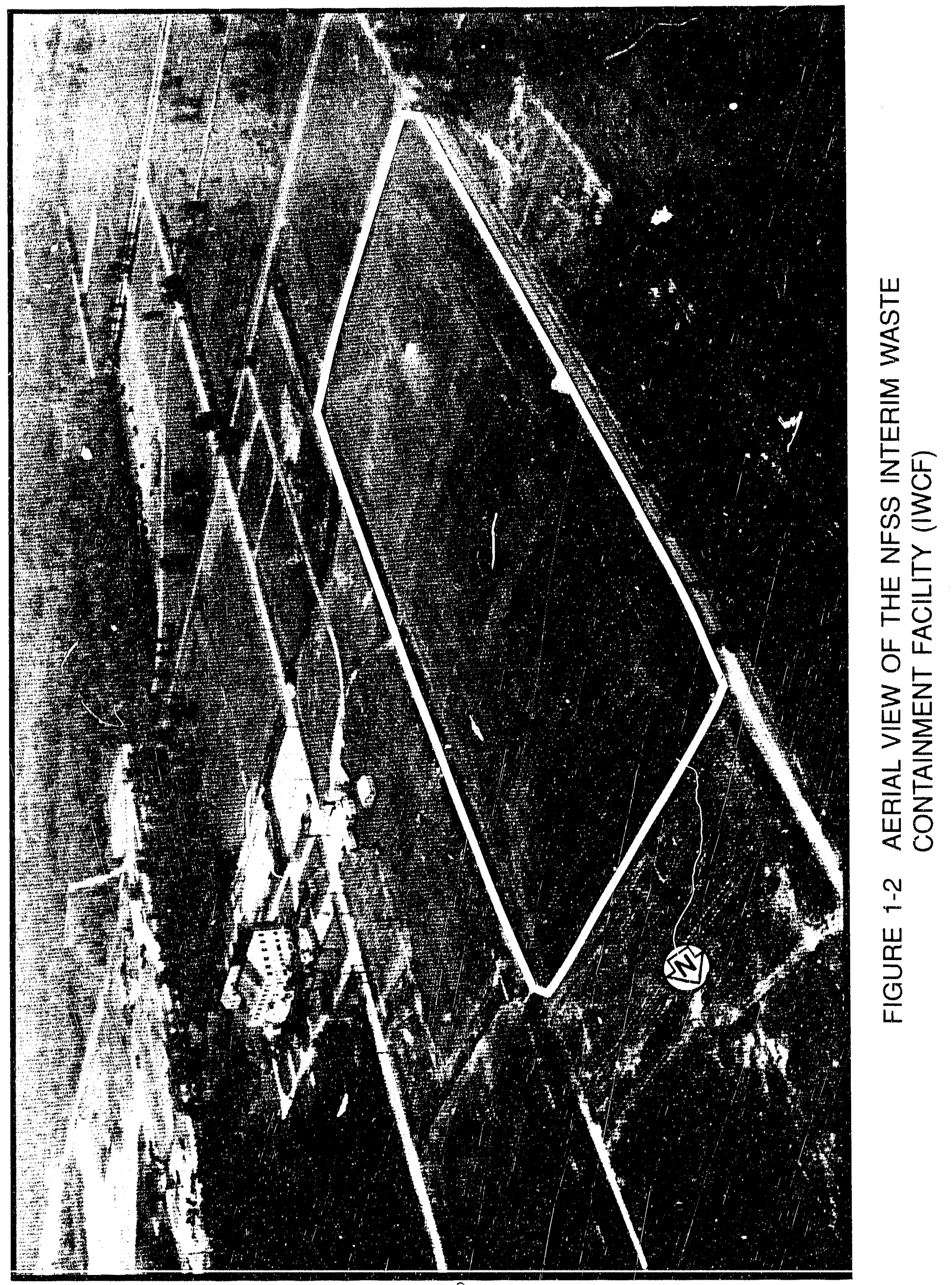




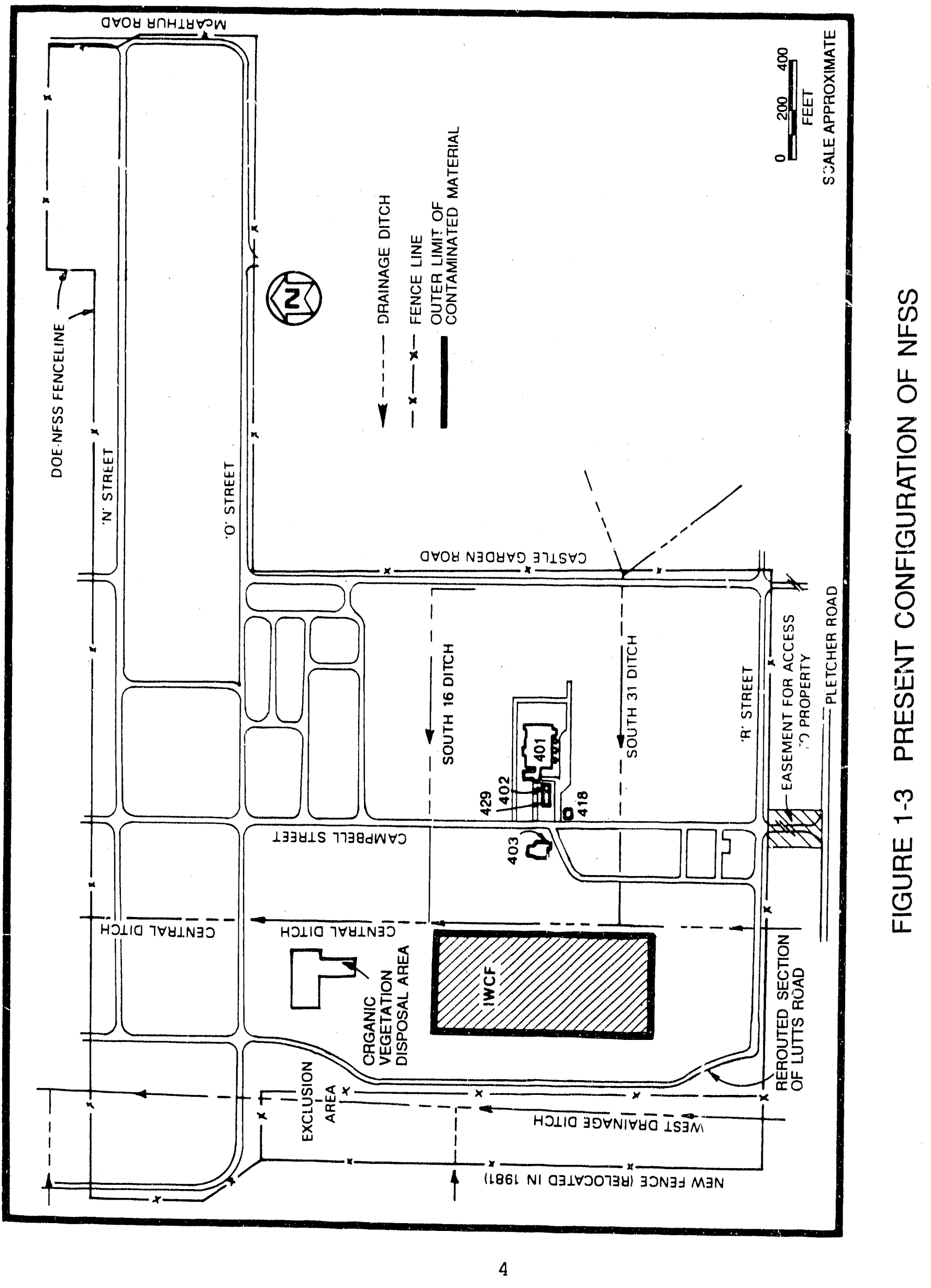


lacustrine clay. Sand-gravel lenses are common. Bedrock lies 9.1 to $15 \mathrm{~m} \mathrm{(30} \mathrm{to} 50 \mathrm{ft}$ ) beneath the surface and consists of queenston shale.

All surface water from the site discharges via the central Drainage Ditch and its tributary ditches into Fourmile creek, located northwest of the site. Groundwater is present in a sand-gravel zone above bedrock and in fractures in the bedrock surface (the primary groundwater system beneath the site) and in saturated clay zones at depths of 1.5 to $6.1 \mathrm{~m}$ ( 5 to $20 \mathrm{ft}$ ). Groundwater level contours indicate that groundwater flows to the north-northwest at a kyaraulic gradient of approximately $3 \mathrm{~m} / \mathrm{km}$ $(16 \mathrm{ft} / \mathrm{mi})$. The groundwater probably discharges into the northern reaches of the Niagara River close to Lake Ontario (Ref. 2).

Lake and river water are the predominant sources of potable water in the area surrounding NFSS; approximately 90 percent of the population in Niagara and Erie counties uses these sources. Water from Lake Erie serves 65 percent of the population, and water from the upper Niagara River serves 25 percent of the population (Ref. 3). Communities north of the Niagara escarpment, including Lewiston and Porter Townships, receive much of their water from these sources.

Groundwater is used to supply approximately 10 percent of the population in Niagara and Erie Counties. The primary uses are for small domestic and farm supplies in rural sections. The dominant source of this water, the Lockport dolomite aquifer, is absent north of the Niagara escarpment, where NFSS is located. Welis in the viciuity of NFSS generally have a low yield and supply water of poor quality. The upper groundwater systems in the glacial deposits near NFSS are sometimes capable of supplying adequate groundwater for domestic use, although these sources may be depleted during dry seasons (Ref. 3 ).

The climate in the NFSS area is classified as humid continental, with a considerable moderating influence from lake ontario. The normal temperature range is -3.9 to $24.4^{\circ} \mathrm{C}(25$ to $\left.76^{\circ} \mathrm{F}\right)$, with a mean annual temperature of $8.9^{\circ} \mathrm{C}\left(48^{\circ} \mathrm{F}\right)$. Mean annual precipitation is $81 \mathrm{~cm}(32 \mathrm{in.})$. Snowfall averages $140 \mathrm{~cm} / \mathrm{yr}$ 
(56 in./yr), accounting for about 10 percent of the annual total precipitation (Ref. 4).

Wind speeds and directions recorded in the vicinity of NFSS are given in Figure 1-4. The data show that the wind originates predominantly from the southwest. The average monthly wind speed ranges from 15 to $23 \mathrm{~km} / \mathrm{h}$ (9.9 to $14 \mathrm{mph}$ ) (Ref. 4).

The primary areas of population near NFSS are the towns of Lewiston (population: 16,200), Niagara (population: 9,650), Porter (population: 7,250), and Niagara Falls City (population: 71,400) (Ref. 3). Almost three-fourths of the 227,000 people residing in Niagara County live in urban areas. Population density in Niagara County in 1980 was about 170 persons $/ \mathrm{km}^{2}$ (430 persons $/ \mathrm{mi}^{2}$ ) (Ref. 3). Land uses immediately adjacent to the site are varied (see Figure 1-5). The site is bordered by a hazardous waste disposal site, a sanitary landfill, and land that is currently vacant.

Land in the vicinity is also used for truck farms, orchards, and rural single-family dwellings. Lewiston-Porter Central Schools are located $2.4 \mathrm{~km}(1.5 \mathrm{mi})$ west of the site on Blairville/Creek Road. The nearest permanent residence is $1.1 \mathrm{~km}(0.68 \mathrm{mi})$ southwest of the site.

\subsection{SITE HISTORY}

NFSS is a remnant of the original 611.5-ha (1,511-acre) site that was used during World War II by the Manhattan Engineer District (MED) project and was a portion of the Department of the Army's Lake Ontario Ordnance Works (LOOW). Except for nonradioactive boron-10 enriching operations during the periods 1954 to 1958 and 1964 to 1971, the site's major use from 1944 to the present has been for the storage of radioactive residues produced as by-products of uranium production during the MED project and subsequent Atomic Energy Commission (AEC) projects. The weight and volume of the residues and sands stored at NFSS are summarized in Table 1-1. Buildings and other features of NFSS existing before recent remedial actions are illustrated in Figure 1-6. 


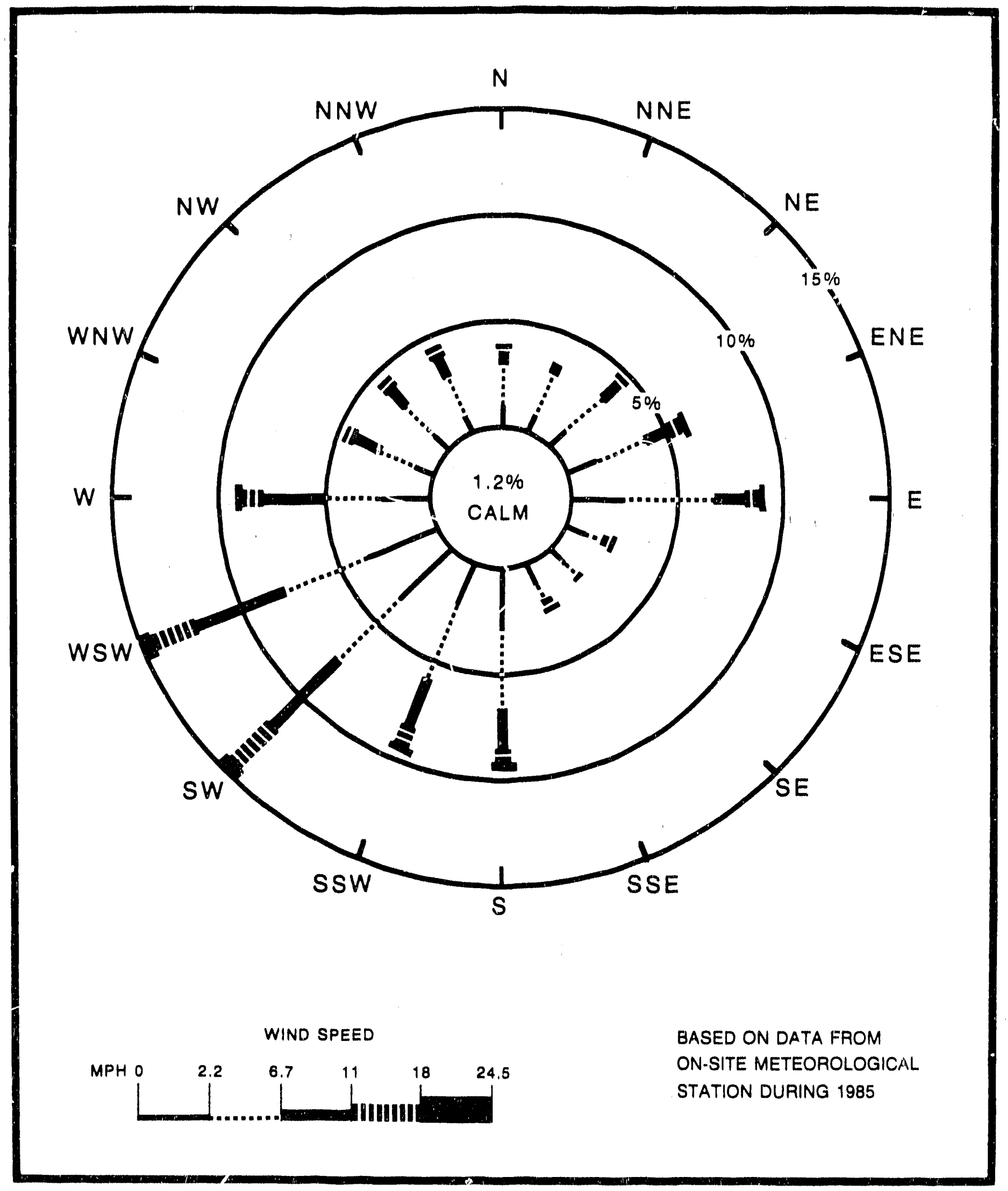

FIGURE 1-4 ANNUAL WIND ROSE FOR NFSS 


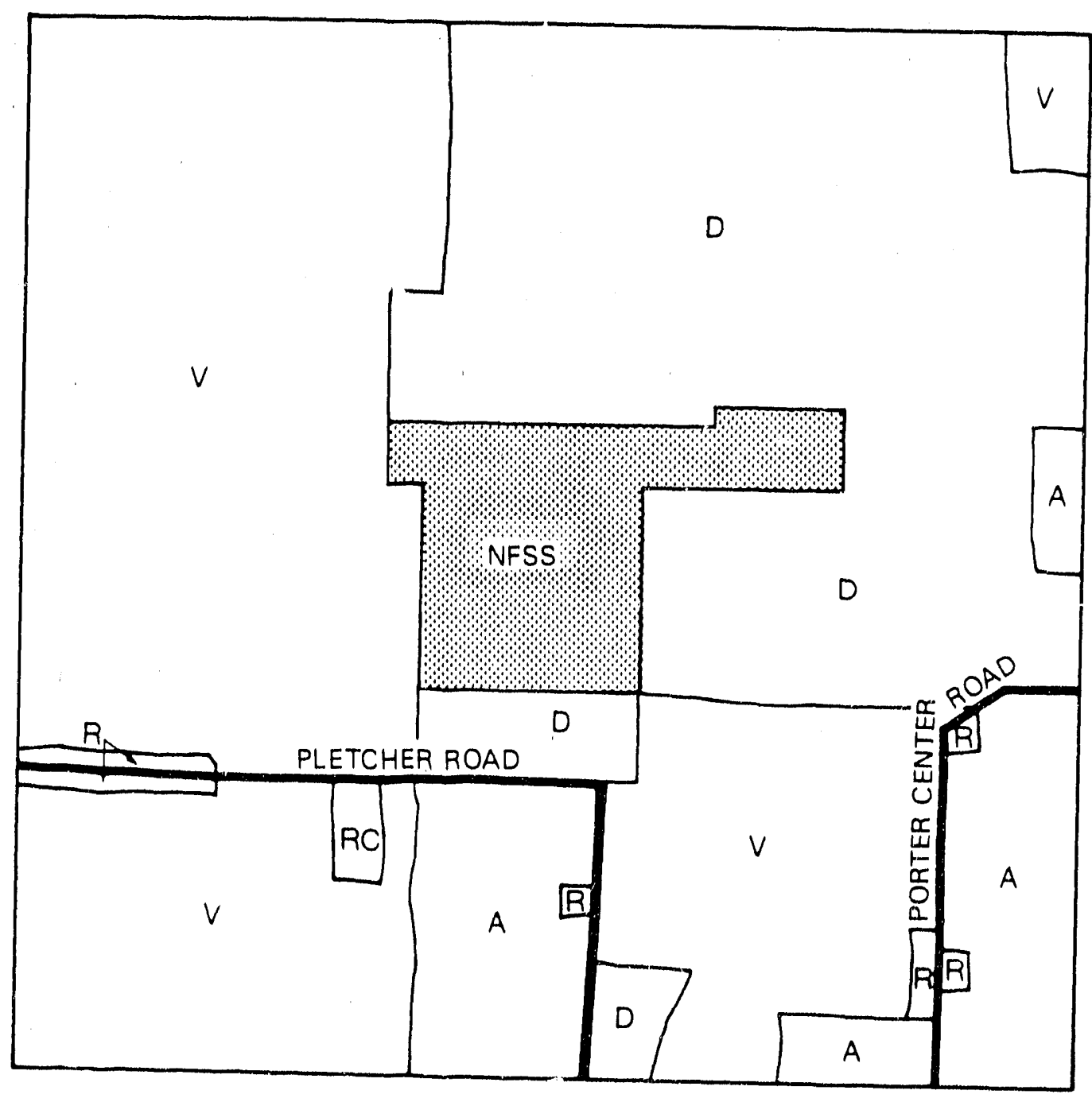
BASED ON AERIAL PHOTOGRAPHS, SITE VISITS, AND USGS TOPOGRAPHIC MAP, 1:24000 SCALE,
RANSOMVILLE QUADRANGLE, (PHOTO REVISED 1980)
R RESIDENTIAL
RC RECREATIONAL
D WASTE DISPOSAL
A AGRICULTURAL
$\checkmark$ VACANT

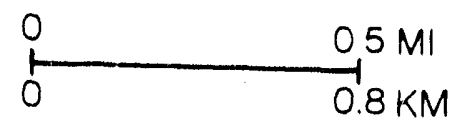

no

FIGURE 1-5 GENERALIZED LAND USE IN THE VICINITY OF NFSS 
TABLE 1-1

RESIDUES AND MIDDI.ESEX SANDS STORED AT NFSS ${ }^{a}$

\begin{tabular}{lrr}
\hline Residue & $\begin{array}{c}\text { Weight } \\
\text { (tons) }\end{array}$ & $\begin{array}{c}\text { Volume } \\
{\left[\mathrm{m}^{3}\left(\mathrm{yd}^{3}\right)\right]}\end{array}$ \\
\hline $\mathrm{K}-65$ & 3,051 & $2,447 \quad(3,200)$ \\
$\mathrm{L}-30$ & 8,227 & $6,086 \quad(7,960)$ \\
$\mathrm{L}-50$ & 1,878 & $1,644 \quad(2,150)$ \\
F-32 & 138 & $336(440)$ \\
R-10 & $8,2.35$ & $7,187 \quad(9,400)$ \\
Middlesex \\
Sands
\end{tabular}

asource: Reference 5 . 


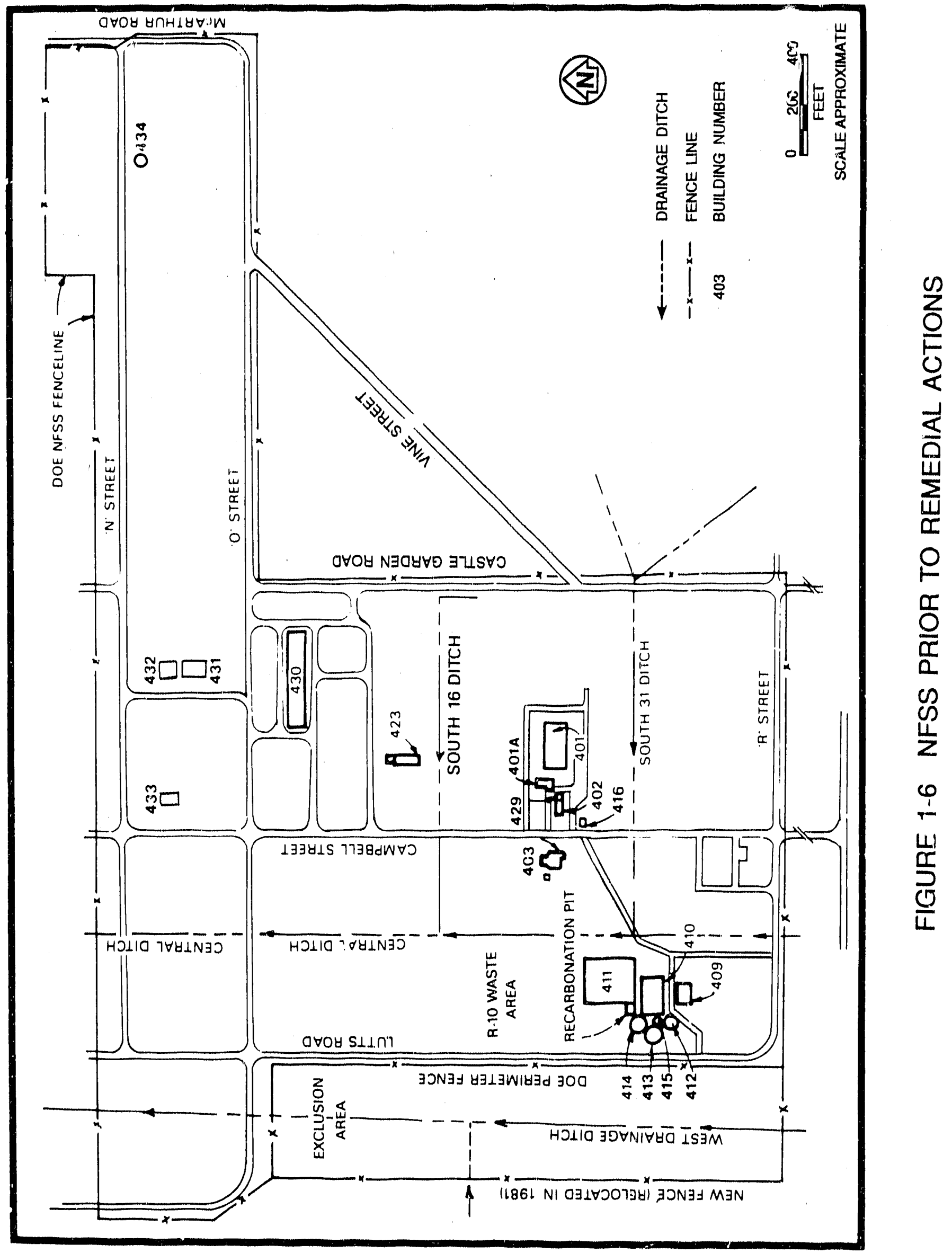


The first materials to arrive at the site were low-grade residues and by-produots from the Linde Air Products Division in Tonawanda, New York (the L-30, L-50, and R-10 residues) and from the Middlesex Sampling Plant in Middlesex, New Jersey (the F-32 residues). The $L-30$ and $L-50$ residues were stored in Buildings 411,413 , and 414 , and the $F-32$ residues were stored in the recarbonation pit directly west of Bullding 411 . The $R-10$ residues and associated iron cake were stored in an open area north of Building 411. These residues were subject to weathering and erosion that transported contaminants into the soil and drainage pathways, resulting in the contamination of other portions of the site and of off-site drainage pathways. A small quantity of Middlesex sands resulting from decontamination activities at the Middlesex Sampling Plant was stored in Building 410. In 1949 pitchblende residues (the K-65 residues) resulting from uranium extraction conducted at a st. Louis plant were transported to the Loow in drums. Some of these were stored outdoors along existing roads and rall lines; others were stored in Building 410. From 1950 to 1952 , the $\mathrm{K}-65$ residues were transferred to a renovated concrete water tower (Building 434).

In 1979, Battelle Columbus Laboratories performed a radiological survey of NFSS. The survey report published by Battelle in June 1981 served as the basis for initial interim remedial action planning for the site (Ref. 5). Bechtel National, Inc. (BNI) was chosen by DOE as the project management contractor for the NFSS project in 1981. BNI helped plan and execute remedial action at the site. BNI currently maintains site security, performs maintenance as required, and implements the environmental monitoring program. Access to the site is controlled by a $2-m-(7-f t-)$ high fence that encloses the DOE property.

Since 1980, "arious steps have been taken at NFSS to minimize potential radiological risks and prevent migration of residues. In the fall of 1980, the vent at the top of Building 434 (the former water tower in which the $\mathrm{K}-65$ residues were stored) was capped to reduce radon emissions to the environment. Also during 1980, pipes 
penetrating the walls of the residue storage bulldings were sealed or resealed as necessary to prevent radionuclide migration.

Because radon levels at the site's western boundary were exceeding DOE Iimits, the site fence was relocated approximately $150 \mathrm{~m}$ (500 ft) to the west in mid-1981, oreating an exclusion area to protect the public from exposure to the higher radon levels. Radon levels at the new boundary were well below applicable guidelines.

In 1981, remedial aotion was performed on a triangular-shaped area adjacent to NFSS, bounded by Vine and 0 streets and Castle Garden Road. Approximately $340 \mathrm{~m}^{3}\left(450 \mathrm{yd}^{3}\right)$ of contaminated material was excavated from this vicinity property and placed in storage.

To further reduce the levels of radon emanating from the site, Buildings 413 and 414 (used for storing the L-50 residues) were upgraded and sealed in 1982. Also in 1982, to prevent further migration of residues, contaminated soll near the $R-10$ plle was moved onto the pile, and a alke and cutoff wall were constructed around the $R-10$ area. The $R-10$ plle was then covered with an ethylene propylene diene monomer (EPDM) liner, which markedly reduced radon emanation from the $R-10$ area. This action effectively reduced radon concentrations at the old site boundary (along Lutts Road) to levels that were below DOE guidelines.

In 1983 and 1984 the EPDM Iiner was removed, additional contaminated soils and rubble from on- and off-site areas were placed on the pile, and the pile was covered with the first layer of the interim clay cap. These actions constituted the beginning of the IWCF. In 1984,93 percent of the $k-65$ residues were transferred from Building 434 to Building 411 .

Construction activities during 1985 included completion of the transfer of K-65 residues from Building 434 to the IWCF, demolition of Building 434 , completion of remedial action on vicinity properties, and continuation of installation of the cap over the wastes in the IWCF. These activities involved excavating approximately $11,000 \mathrm{~m}^{3}\left(14,000 \mathrm{yd}^{3}\right)$ of contaminated materials from on- and off-site areas, transferring $1,109 \mathrm{~m}^{3}\left(1,450 \mathrm{yd}^{3}\right)$ of building rubble to the IWCF, and discharging $12,050,000 \mathrm{~L}$ 
(3,183,000 gal) of treated, impounded water in accordance with New York State Department of Environmental Conservation (NYSDEC) permit requirements. The permit, which explred May 1, 1988, was not renewed becalsse the stte is inactive except for environmental monitoring and survelilance and maintenance of the IWCF.

During 1986, the cap over the IWCF was completed and vibrating wire pressure transducers and pneumatic pressure transducers were installed to monitor the integrity of the waste facility. Also in 1986, another 26 million $L(6.8$ million gal) of contaminated water was treated and released, and four of the six water treatment ponds were reduced to grade. In 1987 the impounded water in the remaining two ponds was treated and released [an additional 38.6 million $L(10.2$ million gal)]. These two ponds were reduced to grade, and NFSS was closed.

The DOE record of decision on the long-term disposition of NFSS was issued in August 1986 . For the radioactive wastes, DOE has selected long-te: m, in-place management consistent with the guidance provided in the U.S. Environmental protection Agency (EPA) regulations governing uranium mill tailings. For the radioactive residues, it is the DOE intent to provide for long-term, in-place management consistent with future applicable EPA guidance. If future analyses show that in-place management cannot meet EPA guidance, another option will be selected that meets EPA guidance and is environmentally acceptable.

In 1988, several isolated areas of residual radioactivity were excavated and the contaminated materials were placed in temporary storage. This material will remain in temporary storage until IWCF is reopened so that additional materials can be added. All of the residual radioactivity on site has been remediated, with the exception of one localized area suspected to be both radiologically and chemically contaminated. This remaining area will be remediated in the future.

There are no continuing commercial, industrial, or remedial activities at NFSS; therefore, there are no airborne radioactive effluents from the site, and waterborne radioactive effluents are limited to extremely low concentrations in surface drainage. 


\subsection{HYDROGEOLOGICAL CHARACTERISTICS OF THE SITE}

The interpretations presented here are based on monthly groundwater levels measured during calendar year 1989. Fewer groundwater monitoring wells were actively monitored in 1989 (Figure 1-7) than in previous years (Ref. 6). The 1989 data do not vary substantially from those obtained in previous years

(Refs. 7-13). A summary of well construction information is shown in Tables 1-2 and 1-3. Examples of well construction details are presented in Appendix E.

The three groundwater systems monitored at NFSS have been referred to as "upper," "lower," and "bedrock" by previous investigators. The lower and bedrock systems are thought to be hydraulically connected, but for the purposes of this discussion they are described separately. Further background information on site geology, hydrogeology, and well installation methods can be found in Refs. 2 and 14 through 16.

\subsubsection{Opper Groundwater System}

The upper groundwater system occurs in a zone of discontinuous silts, sands, and clays approximately 1.5 to $8.5 \mathrm{~m}$ (5 to $28 \mathrm{ft}$ ) below ground surface (Ref. 2). Wells in this zone are screened in unconsolidated silts and sands at depths of 2.4 to $6.7 \mathrm{~m}$ (8 to $22 \mathrm{ft})$. Elevations of water levels measured in upper system wel. Is in 1989 are shown as hydrographs in Figures 1-8 through 1-12. Precipitation records for NFSS as measured on site are presented in Figure 1-8. The upper system water levels display seasonal variation, with the highest value occurring in the spring and the lowest in the fall.

The hydrographs show inconsistent correlation in groundwater levels from well to well, probably because of the discontinuous nature of the screened materials over the distance between the wells. 


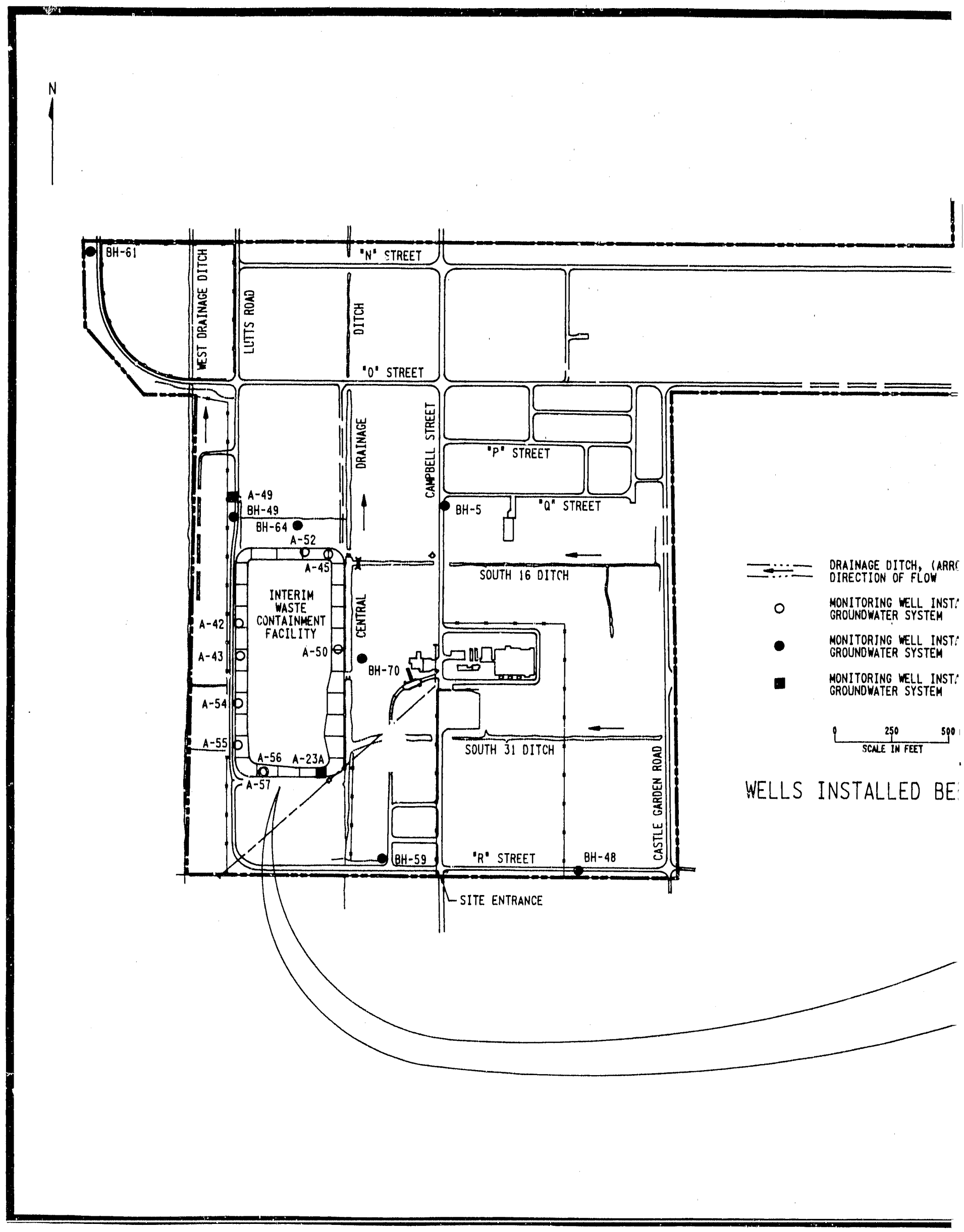


TABLE 1-2

NFSS UPPER SYSTEM MONITORING WEIL CONSTRUCTION SUMMARY

\begin{tabular}{|c|c|c|c|c|c|c|}
\hline $\begin{array}{l}\text { Well } \\
\text { Number }\end{array}$ & $\begin{array}{l}\text { Completion } \\
\text { Date }\end{array}$ & $\begin{array}{l}\text { Tol } \\
\text { Del } \\
{[\mathrm{m}}\end{array}$ & $\begin{array}{l}\text { al } \\
\text { th } \\
(\mathrm{ft})]\end{array}$ & $\begin{array}{l}\text { Monitar } \\
\text { screened } \\
\text { Below } \\
\text { [m-m (ft }\end{array}$ & $\begin{array}{l}\text { ced or } \\
\text { Interval } \\
\text { ground } \\
(-\mathrm{ft})]\end{array}$ & $\begin{array}{l}\text { Construction } \\
\text { Material }\end{array}$ \\
\hline$A-42$ & Mar. 1983 & 6.86 & $(22.5)$ & $3.17-6.86$ & $(10.4-22.5)$ & PVC $^{\mathrm{a}}$ \\
\hline$A-43$ & Mar. 1983 & 4.27 & $(14.0)$ & $2.1-4.27$ & $(7.0-14.0)$ & PVC \\
\hline$A-45$ & Mar. 1983 & 6.10 & $(20.0)$ & $2.4-6.10$ & $(8.0-20.0)$ & PVC \\
\hline$A-50$ & Mar. 1983 & 7.01 & $(23.0)$ & $3.05-6.71$ & $(10.0-22.0)$ & PVC \\
\hline$A-52$ & Mar. 1983 & 4.58 & $(15.0)$ & $1.8-4.58$ & $(6.0-15.0)$ & PVC \\
\hline$O N-1 B$ & Oct. 1986 & 5.18 & $(17.0)$ & $3.11-4.73$ & $(10.2-15.5)$ & 316 stainless steel \\
\hline$O W-2 B$ & Sept. 1986 & 6.10 & $(20.0)$ & $4.12-5.64$ & $(13.5-18.5)$ & 316 Stainless Steel \\
\hline$O W-3 B$ & Oct. 1986 & 4.88 & $(16.0)$ & $2.9-4.42$ & $(9.5-14.5)$ & 316 stainless steel \\
\hline OW $-4 B$ & oct. 1986 & 5.18 & $(17.0)$ & $3.11-4.73$ & $(10.2-15.5)$ & 316 Stainless Steel \\
\hline$O W-5 B$ & oct. 1986 & 5.18 & $(17.0)$ & $2.9-4.42$ & $(9.5-14.5)$ & 316 Stainless Steel \\
\hline$O W-6 B$ & oct. 1986 & 5.18 & $(17.0)$ & $3.14-4.73$ & $(10.3-15.5)$ & 316 Stainless Steel \\
\hline$O W-7 B$ & oct. 1986 & 3.97 & $(13.0)$ & $1.9-3.45$ & $(6.3-11.3)$ & 316 Stainless Steel \\
\hline$O W-8 B$ & Nov. 1986 & 3.66 & $(12.0)$ & $1.7-3.20$ & $(5.5-10.5)$ & 316 stainless steel \\
\hline$O W-9 B$ & Nov. 1986 & 4.45 & $(14.6)$ & $2.5-4.03$ & $(8.2-13.2)$ & 316 Stainless Steel \\
\hline$O W-10 B$ & Nov. 1986 & 8.85 & $(29.0)$ & $5.28-8.42$ & $(17.3-27.6)$ & 316 Stainless Steel \\
\hline$O N-11 B$ & Nov. 1986 & 4.88 & $(16.0)$ & $2.3-3.81$ & $(7.5-12.5)$ & 316 Stainless Steel \\
\hline$O W-12 B$ & Nov. 1986 & 3.66 & $(12.0)$ & $1.8-3.29$ & $(5.8-10.8)$ & 316 stainless Steel \\
\hline$O N-13 B$ & Nov. 1986 & 4.27 & $(14.0)$ & $2.2-3.72$ & $(7.2-12.2)$ & 316 Stainless Steel \\
\hline$O W-14 B$ & oct. 1986 & 4.64 & $(15.2)$ & $2.6-4.12$ & $(8.5-13.5)$ & 316 stainless steel \\
\hline$O W-15 B$ & oct. 1986 & 3.66 & $(12.0)$ & $1.7-3.26$ & $(5.7-10.7)$ & 316 Stainless Steel \\
\hline$O W-16 B$ & oct. 1986 & 3.97 & $(13.0)$ & $2.1-3.63$ & $(6.9-11.9)$ & 316 Stainless Steel \\
\hline$O W-17 B$ & oct. 1986 & 5.18 & $(17.0)$ & $3.20-4.73$ & $(10.5-15.5)$ & 316 Stainless steel \\
\hline$O W-18 B$ & oct. 1986 & 5.06 & $(16.6)$ & $3.11-4.64$ & $(10.2-15.2)$ & 316 Stainless Steel \\
\hline
\end{tabular}

$a_{\text {PVC - polyvinyl chloride. }}$ 
TABLE 1-3

NFSS MONITORING WEIL CONSTRUCTION SUMMARY

FOR LOWER AND BEDROCK GROUNDWATER SYSTEMS

Page 1 of 2

\begin{tabular}{|c|c|c|c|c|}
\hline $\begin{array}{l}\text { Well } \\
\text { Number }\end{array}$ & $\begin{array}{c}\text { Campletion } \\
\text { Date }\end{array}$ & $\begin{array}{l}\text { Total } \\
\text { Depth } \\
{[m(f t)]}\end{array}$ & $\begin{array}{l}\text { Monitored or } \\
\text { Screened Interval } \\
\text { Below Ground } \\
{[\mathrm{m}-\mathrm{m}(\mathrm{ft}-\mathrm{ft})]}\end{array}$ & $\begin{array}{c}\text { Construction } \\
\text { Material }\end{array}$ \\
\hline
\end{tabular}

Wells Installed in Bedrock

$\begin{array}{llllll}\text { A-23A } & \text { Mar. } 1983 & 23.9(78.5) & 12.2-23.3(40.0-76.3) & \text { PVC }^{\mathrm{a}} \\ \text { A-35 } & \text { Mar. } 1983 & 24.4(80.1) & 12.2-24.7(40.0-81.0) & \text { PVC } \\ \text { A-49 } & \text { Mar. } 1983 & 27.5(90.0) & 14.0-27.5(46.0-90.0) & \text { PVC } \\ & & & & \\ \text { BH-12 } & \text { June } 1981 & 29.0(95.0) & 13.4-29.0(44.0-95.0) & \text { PVC } \\ \text { BH-15 } & \text { June } 1981 & 31.9(104.5) & 16.5-31.9(54.0-104.5) & \text { PVC } \\ \text { BH-57 } & \text { June } 1981 & 31.0(101.5) & 15.0-31.0(49.0-101.5) & \text { PVC } \\ \text { BH-62 } & \text { June } 1981 & 30.0(98.0) & 15.0-30.0(49.0-98.0) & \text { PVC }\end{array}$

Wells Installed in Soil (Lower System)

\begin{tabular}{|c|c|c|c|c|}
\hline $\mathrm{BH}-46$ & June 1981 & $16.5(54.0)$ & $7.6-14.7 \quad(25.0-48.3)$ & PVC \\
\hline $\mathrm{BH}-48$ & May 1981 & $13.4(44.0)$ & $5.5-11.3(18.0-37.1)$ & PVC \\
\hline $\mathrm{BH}-49$ & May 1981 & $15.5(50.9)$ & $8.2-14.3 \quad(27.0-47.0)$ & PVC \\
\hline $\mathrm{BH}-5$ & June 1981 & $15.9(52.2)$ & $7.3-14.4 \quad(24.0-47.2)$ & PVC \\
\hline $\mathrm{BH}-50$ & May 1981 & $13.4(44.0)$ & $6.2-11.7 \quad(20.3-38.3)$ & PVC \\
\hline $\mathrm{BH}-59$ & May 1981 & $12.4(40.5)$ & $7.0-11.5(23.0-37.7)$ & PVC \\
\hline BH -60 & May 1981 & $14.0(45.8)$ & $6.4-12.4 \quad(21.0-40.5)$ & PVC \\
\hline $\mathrm{BH}-61$ & May 1981 & $14.0(46.0)$ & $7.3-12.7 \quad(24.0-41.6)$ & PVC \\
\hline $\mathrm{BH}-6 \mathrm{i}$ & June 1981 & $14.9(48.7)$ & $8.5-13.1(28.0-43.0)$ & PVC \\
\hline $\mathrm{BH}-70$ & Jume 1981 & $13.7(45.0)$ & $6.1-12.2(20.0-40.0)$ & SNC \\
\hline
\end{tabular}

OW-1A Oct. $1986 \quad 14.3(47.0) \quad 10.6-13.7(34.8-45.0) \quad 316$ stainless Steel

OW-2A Oct. $1986 \quad 14.0(46.0) \quad 10.3-13.4(33.7-44.0) \quad 316$ Stainless Steel

ow-3A oct. $1986 \quad 12.8(42.0) \quad 9.9-11.4(32.4-37.4) \quad 316$ stainless steel 
TABLE 1-3

(continued)

Page 2 of 2

Monitored or Screened Interval

\begin{tabular}{|c|c|c|c|c|}
\hline $\begin{array}{l}\text { Well. } \\
\text { Number }\end{array}$ & $\begin{array}{c}\text { Completion } \\
\text { Date }\end{array}$ & $\begin{array}{l}\text { Total } \\
\text { Depth } \\
{[\mathrm{m} \text { (ft) }]}\end{array}$ & $\begin{array}{l}\text { Screened Interval } \\
\text { Below Ground } \\
{[\mathrm{m}-\mathrm{m} \text { (ft-ft) }}\end{array}$ & $\begin{array}{c}\text { Construction } \\
\text { Material }\end{array}$ \\
\hline
\end{tabular}

Wells Installed in soil (continued)

\begin{tabular}{|c|c|c|c|c|c|c|}
\hline$O W-4 A$ & oct. 1986 & 12.4 & $(40.6)$ & $8.6-11.7(28.1-38.4)$ & 316 stainless & Steel \\
\hline$O W-5 A$ & Oct. 1986 & 13.5 & $(44.3)$ & $9.8-12.8(32.0-42.0)$ & 316 stainless & Ste \\
\hline$O W-6 A$ & oct. 1986 & 12.3 & $(40.2)$ & $8.6-11.7(28.1-38.4)$ & 316 stainless & Steel \\
\hline$O W-7 A$ & oct. 1986 & 12.1 & $(39.6)$ & $8.5-11.7 \quad(27.9-38.2)$ & 316 Stainless & \\
\hline$O W-8 A$ & Nov. 1986 & 13.6 & $(44.6)$ & $10.0-13.1(32.7-43.0)$ & 16 Stainless & Stee \\
\hline$O W-9 A$ & Nov. 1986 & 12.5 & $(41.1)$ & $8.7-11.9(28.6-38.9)$ & 16 stainless & \\
\hline$O W-10 A$ & Nov. 1986 & 12.3 & $(40.3)$ & $10.2-11.7 \quad(33.5-38.5)$ & 16 Stainless & \\
\hline$O W-11 A$ & Nov. 1986 & 1.1 .4 & $(37.2)$ & $7.7-10.8 \quad(25.2-35.5)$ & 316 stainless & \\
\hline$O W-12 A$ & Nov. 1986 & 11.7 & $(38.3)$ & $7.6-12.1(25.0-39.7)$ & 6 Stainless & \\
\hline$O W-13 A$ & oct. 1986 & 12.5 & $(41.1)$ & $9.0-13.2(29.4-43.4)$ & 316 stainless & \\
\hline$O W-14 A$ & oct. 1986 & 13.7 & $(44.8)$ & $10 .(-13.2(33.1-43.4)$ & 16 Stainless & \\
\hline$O W-15 A$ & oct. 1986 & 13.9 & $(45.5)$ & $11.9-13.4(39.0-44.0)$ & 316 stainless & \\
\hline$O W-16 A$ & Oct. 1986 & 13.8 & $(45.2)$ & $9.9-13.0(32.4-42.7)$ & 316 Stainless & \\
\hline$O W-17 A$ & oct. 1986 & 13.0 & $(42.5)$ & $9.2-12.3(30.1-40.4)$ & 16 Stainless & \\
\hline$O W-18 A$ & Oct. : & 14.6 & $(47.8)$ & $10.9-14.0(35.7-46.0)$ & Stainless & \\
\hline
\end{tabular}

$a_{\text {PVC - polyvinyl chloride. }}$ 


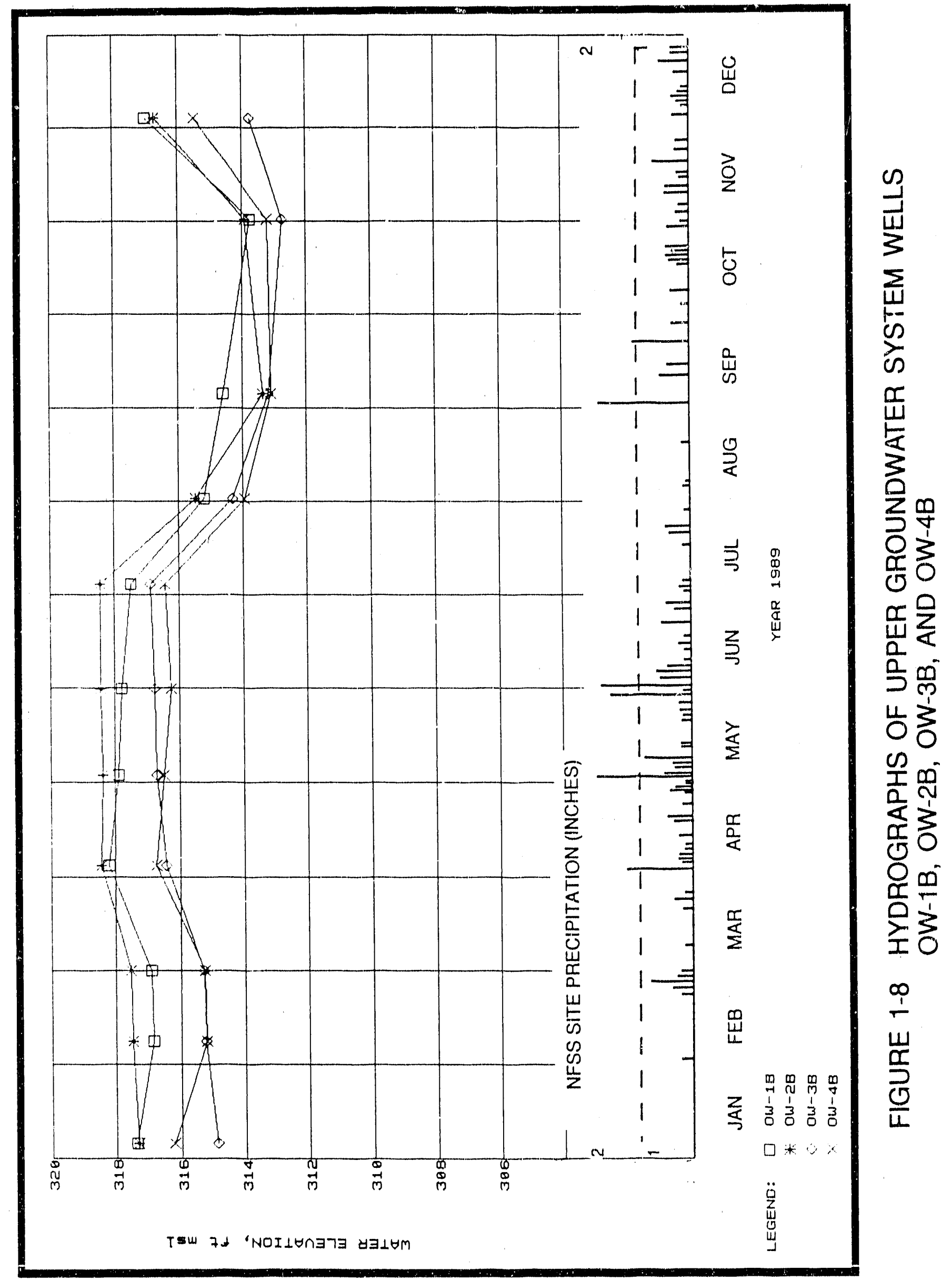




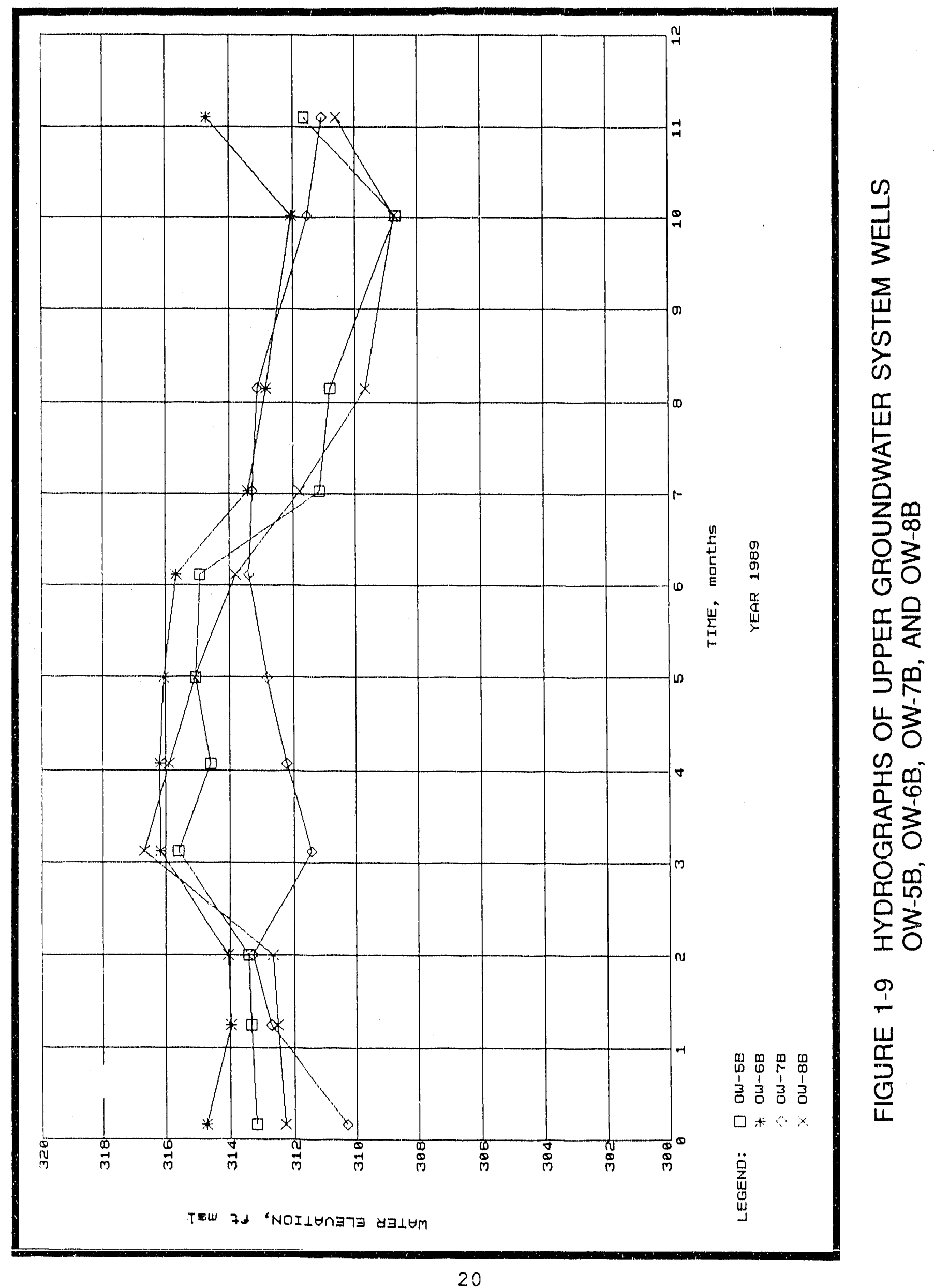




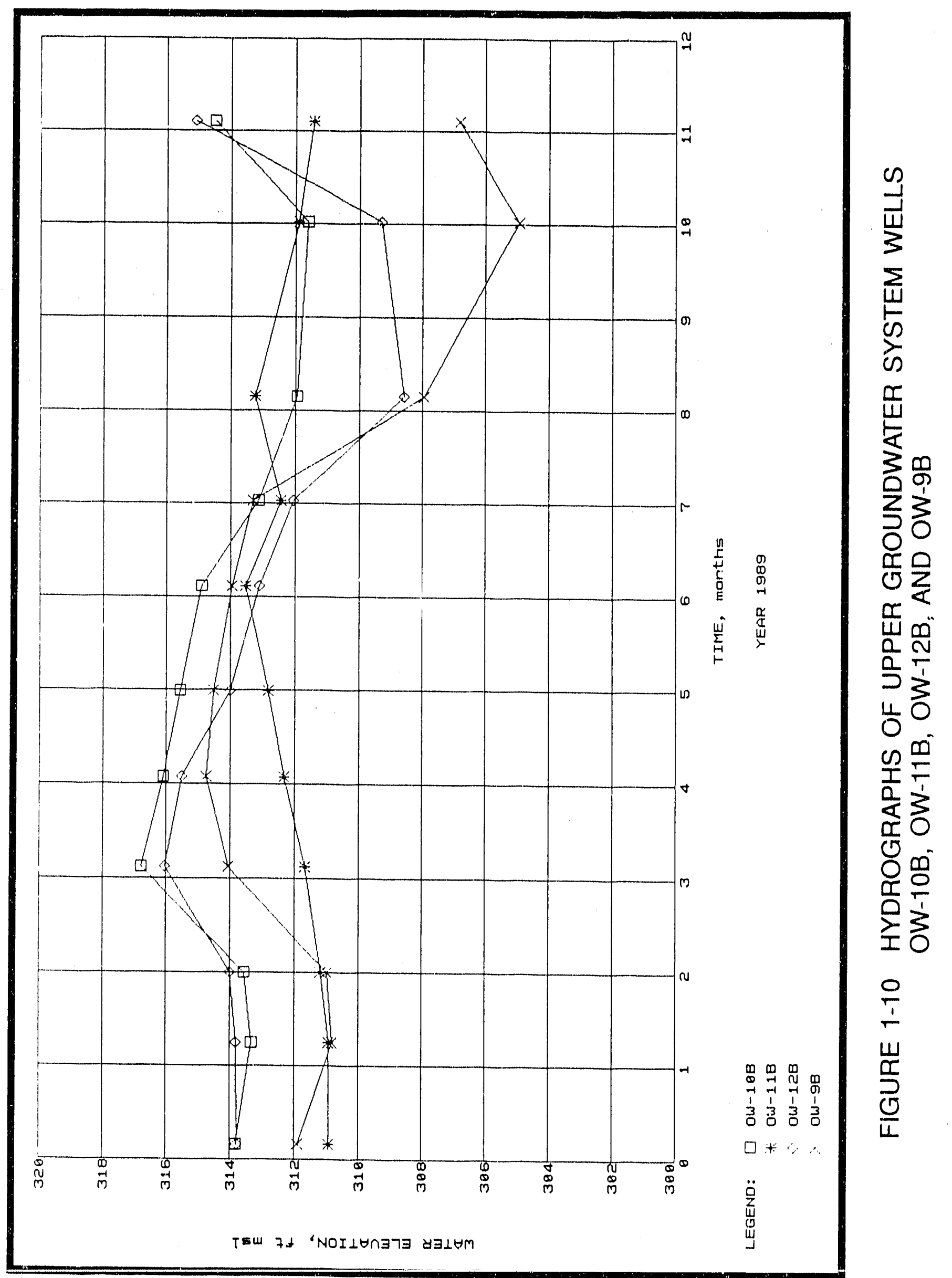




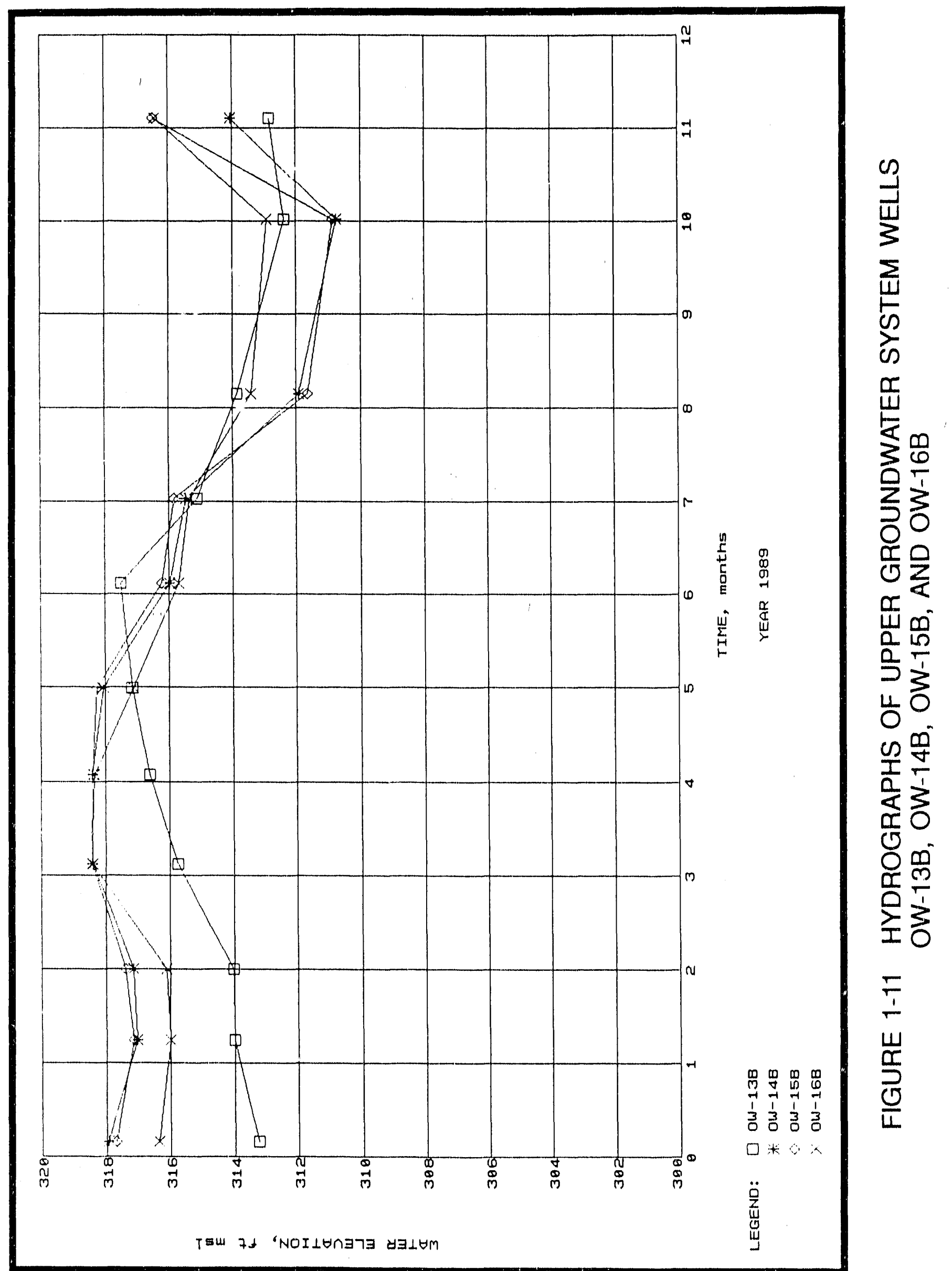




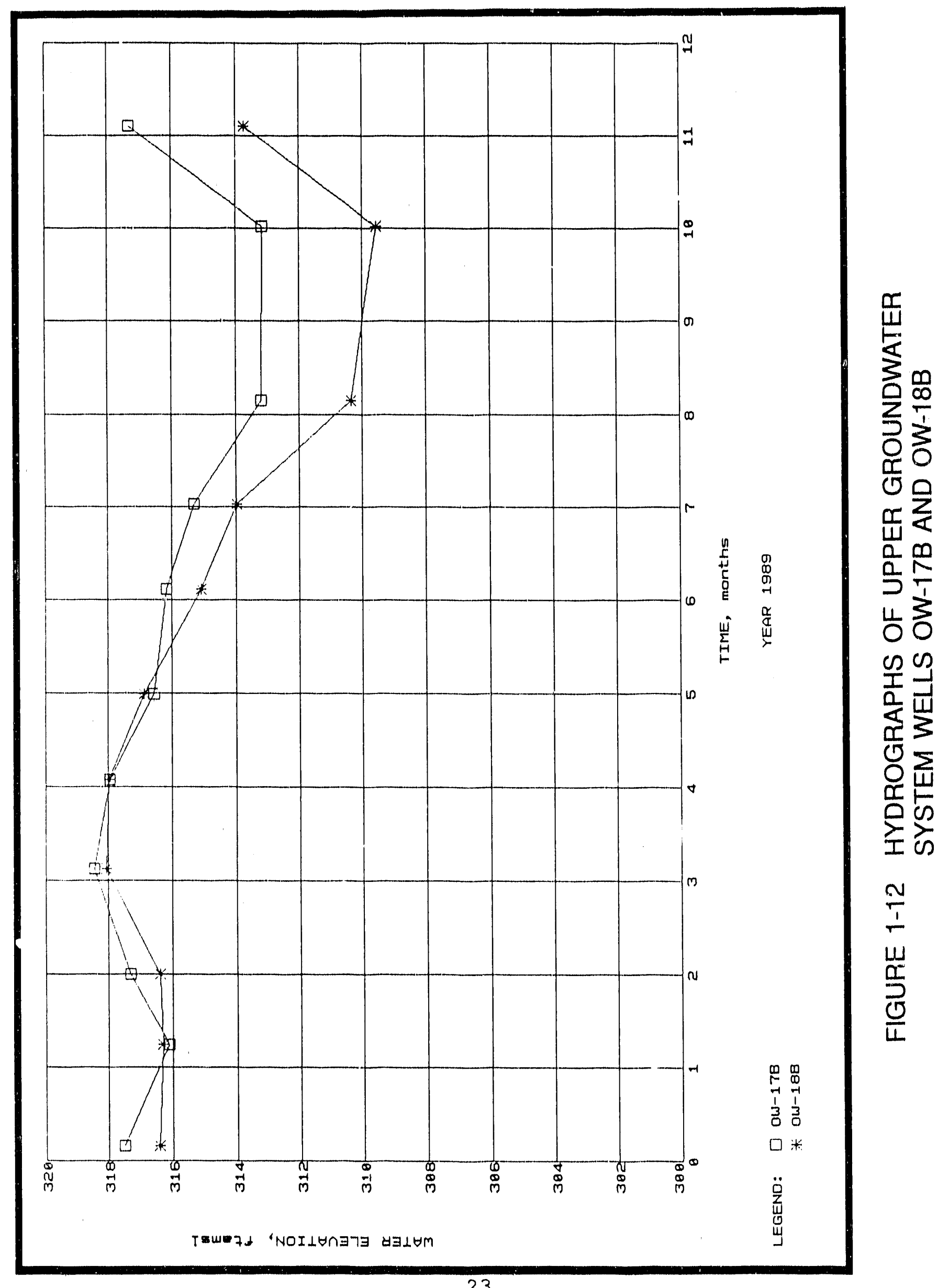


Because of the horizontal discontinuities in the unoonsolidated materials that contain the upper groundwater system, potentiometric surface maps were not prepared. (Potentiometric surface is defined as the level to which water will rise in tightly cased welis. Delineation of the potentiometrio surface of an aquifer indicates groundwater hydraulic gradient and flow direotion.) Therefore, gradient and flow direction are not presented for this system.

\subsubsection{Lower Groundwater System}

The silt and sand layer that contains the lower groundwater system is approximately 9.2 to $14 \mathrm{~m}$ (30 to $45 \mathrm{ft}$ ) below ground surface. This layer is between an underlying red silt and an overlying gray clay and is in hydraulic connection with the bedrock system. The water-bearing red silt zone above bedrock is absent in a few locations across the site (Ref. 2).

Hydrographs of wells screened in the lower groundwater system (Figures 1-13 through 1-19) show a definite seasonal variation of water levels. The water levels are highest in the summer [about $315 \mathrm{ft}$ above mean sea level (ft $\mathrm{msl}$ )] and lowest in the winter (about $310 \mathrm{ft} \mathrm{ms} 1$ ). Except for $B H-64, O W-7 A$, and $O W-11 \mathrm{~A}$, all of the hydrographs appear to correlate well with each other.

Wells BH-64 (Figure 1-18), OW-7A (Figure 1-14), and OW-11A (Figure 1-15), which are screened in the lower groundwater system, show irregular water level elevations with respect to the other lower system wells (Ref. 13). The behavior of these three wells correlates more with the upper groundwater system than with the lower (Figure 1-20), which explains the anomalous groundwater elevations shown in Figure 1-22.

Gradient and flow direction for the lower groundwater system in 1989 were determined using two potentiometric surface maps (Figure 1-21 for July 5 and Figure $1-22$ for November 11). The dates chosen are representative of water levels during high and low periods. 


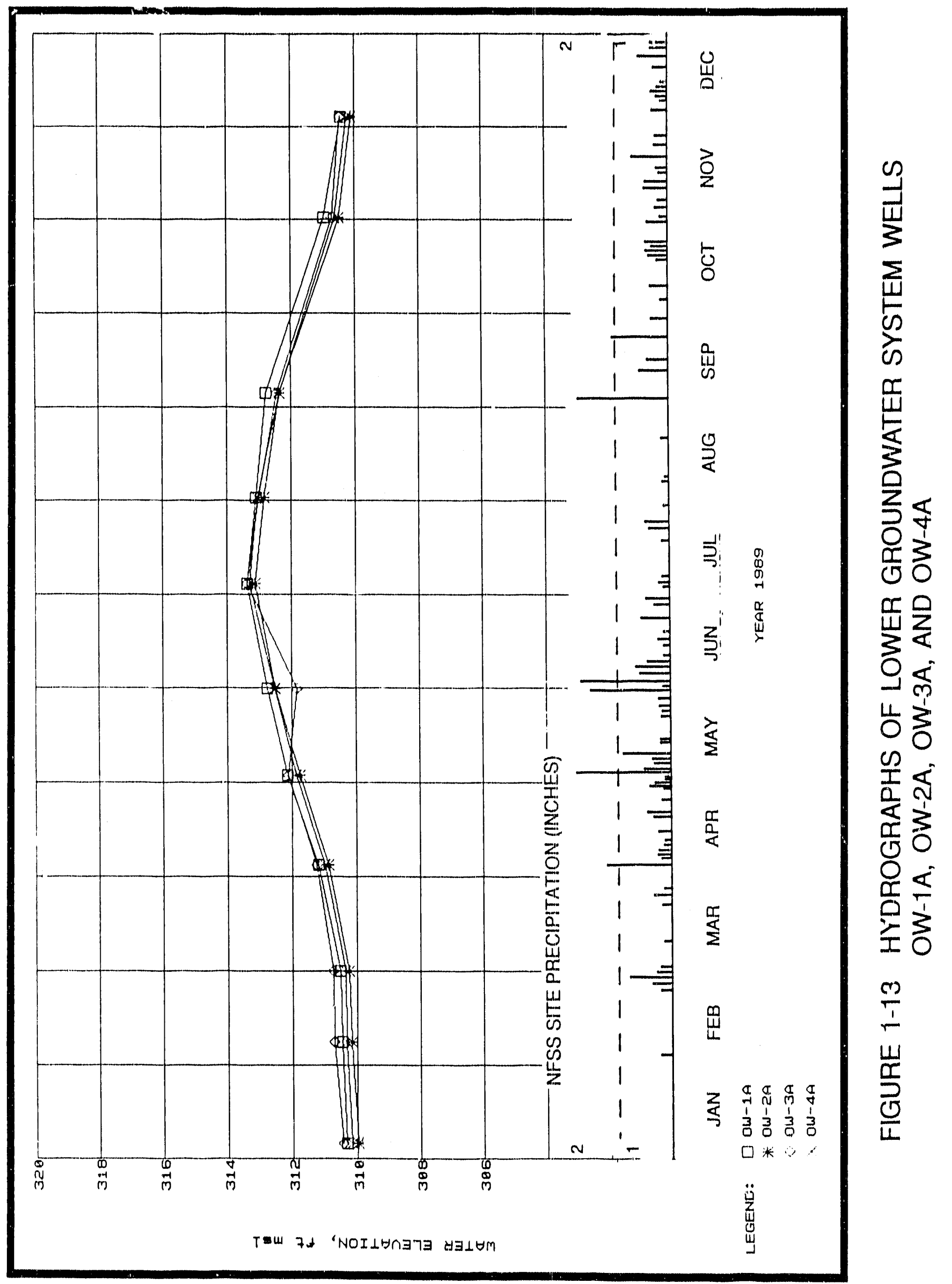




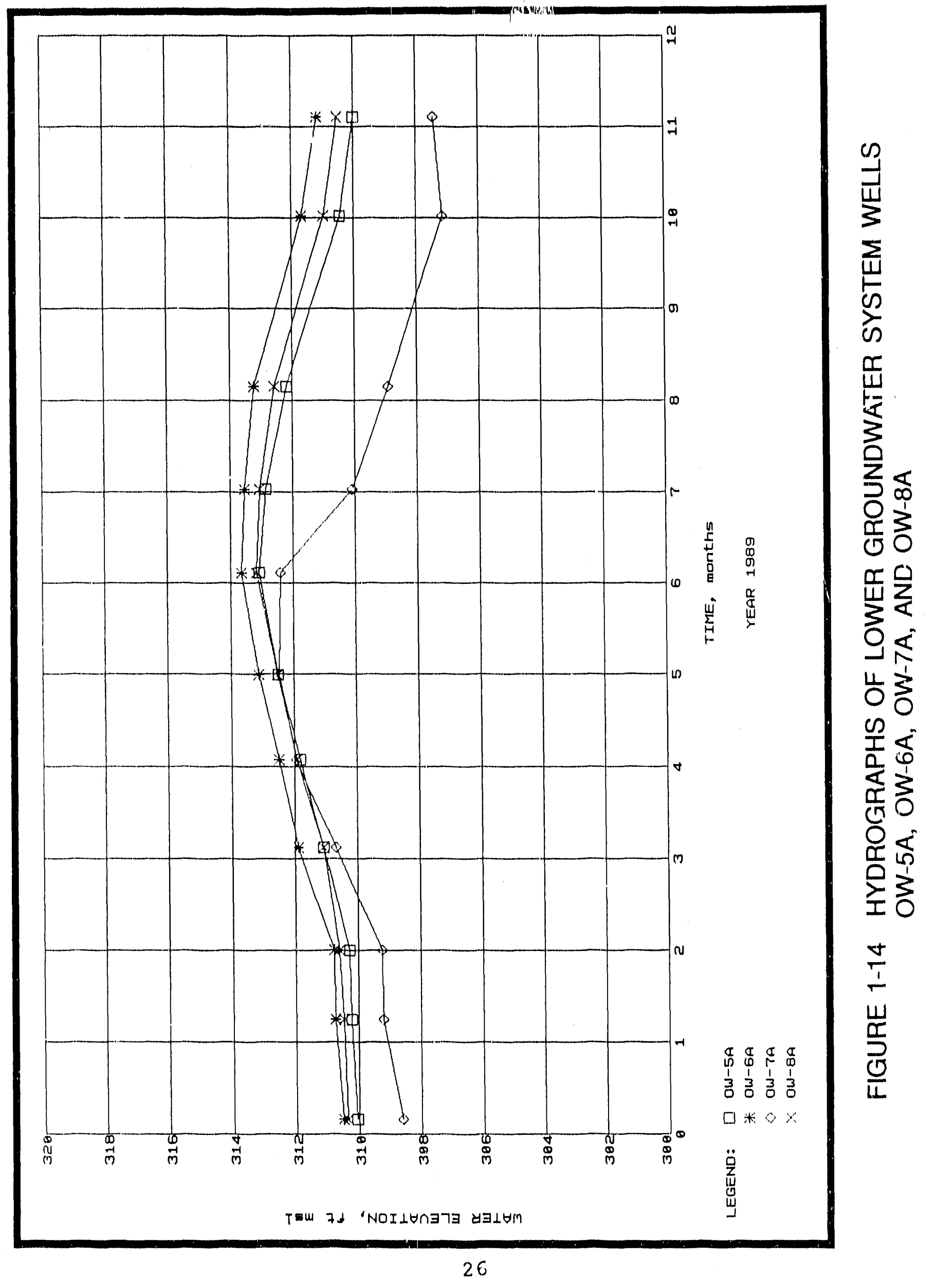




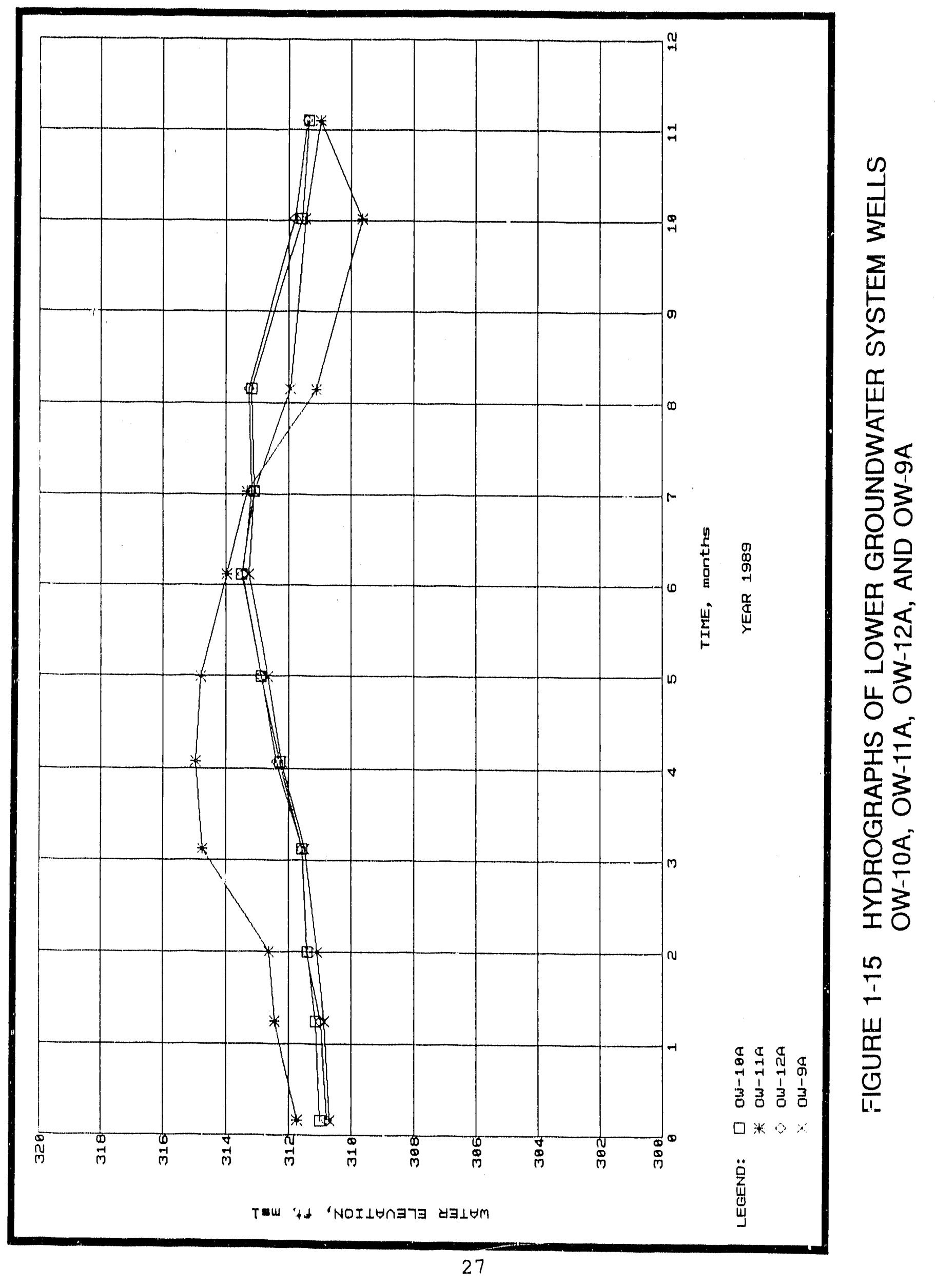




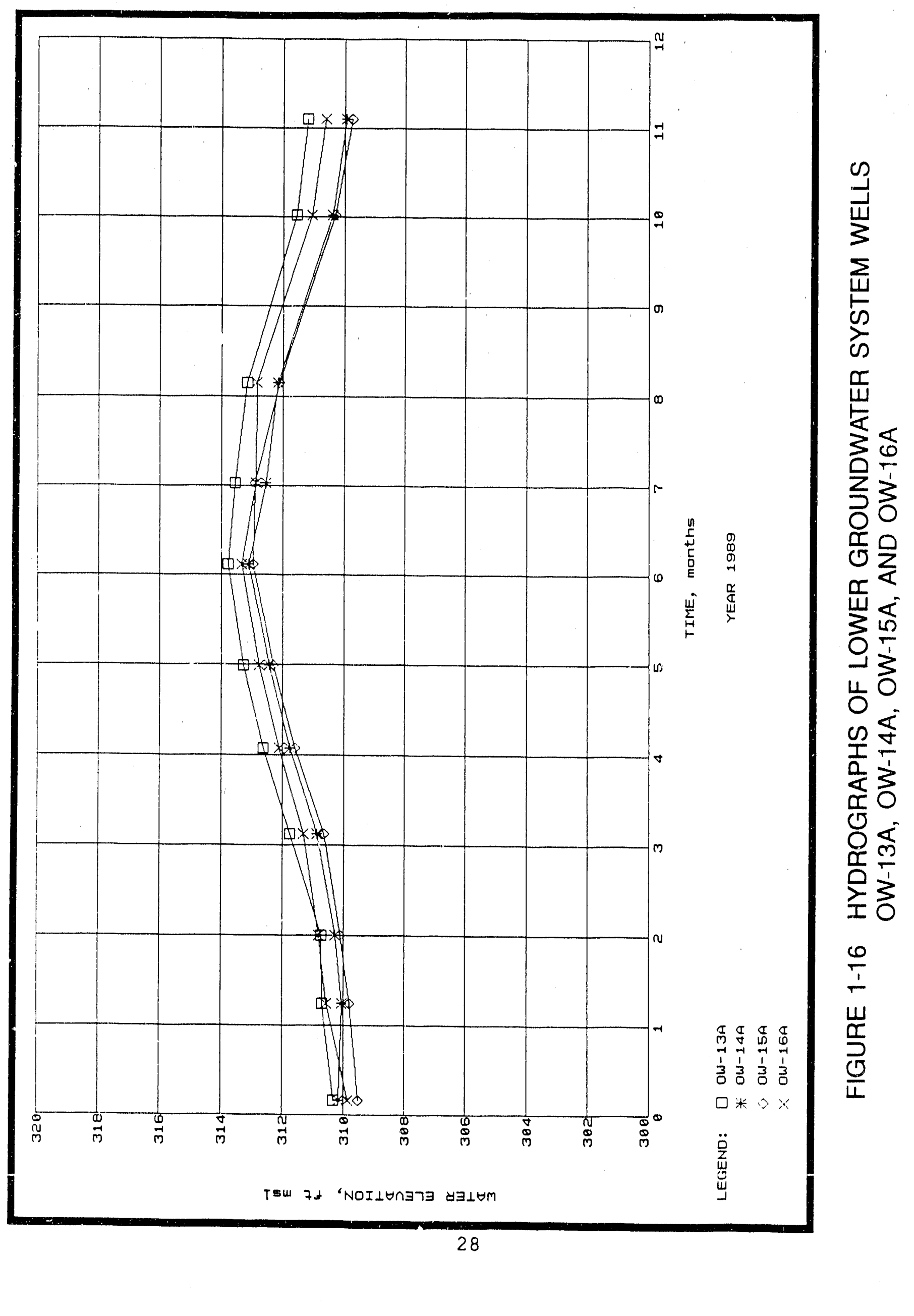




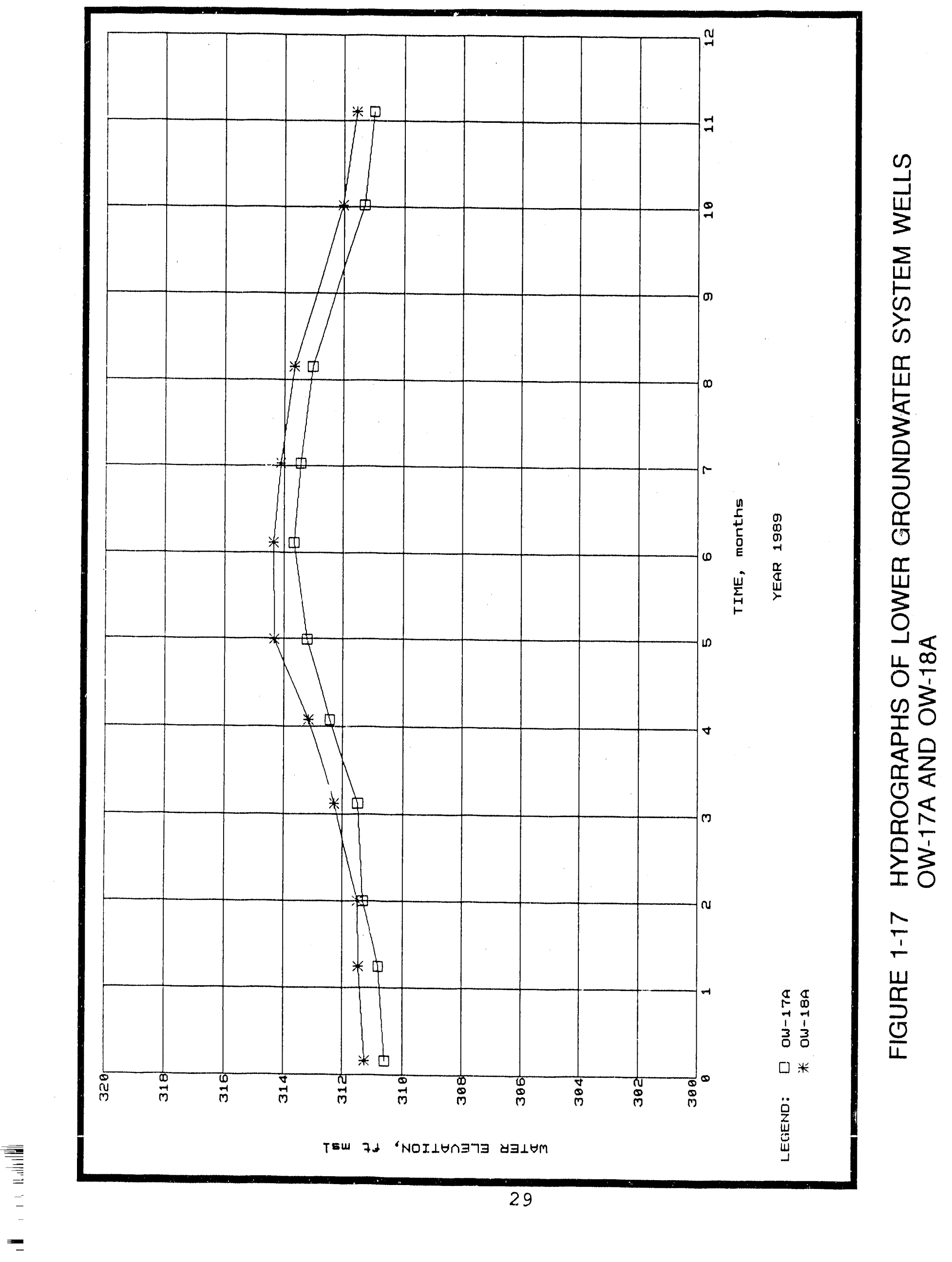




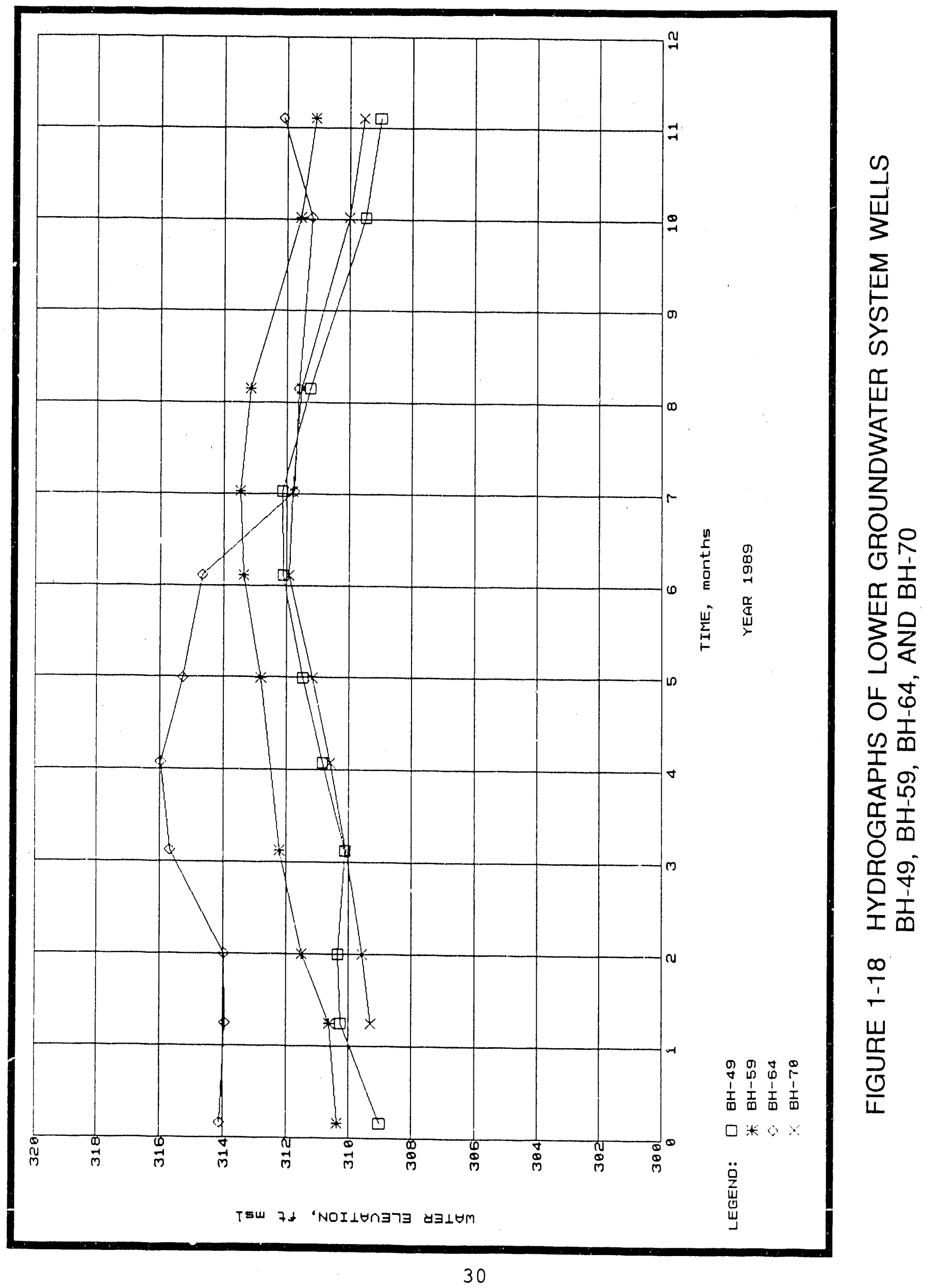




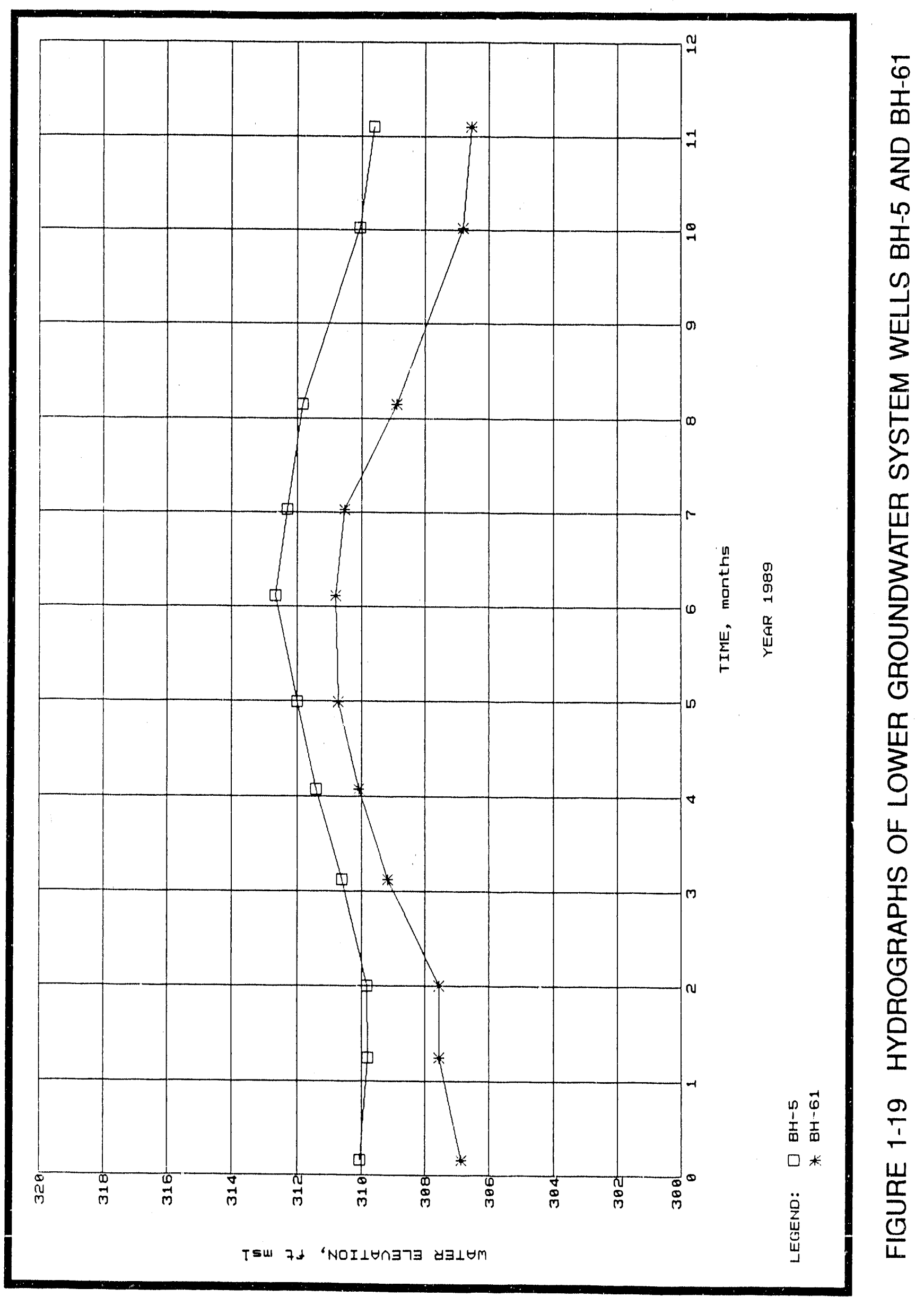




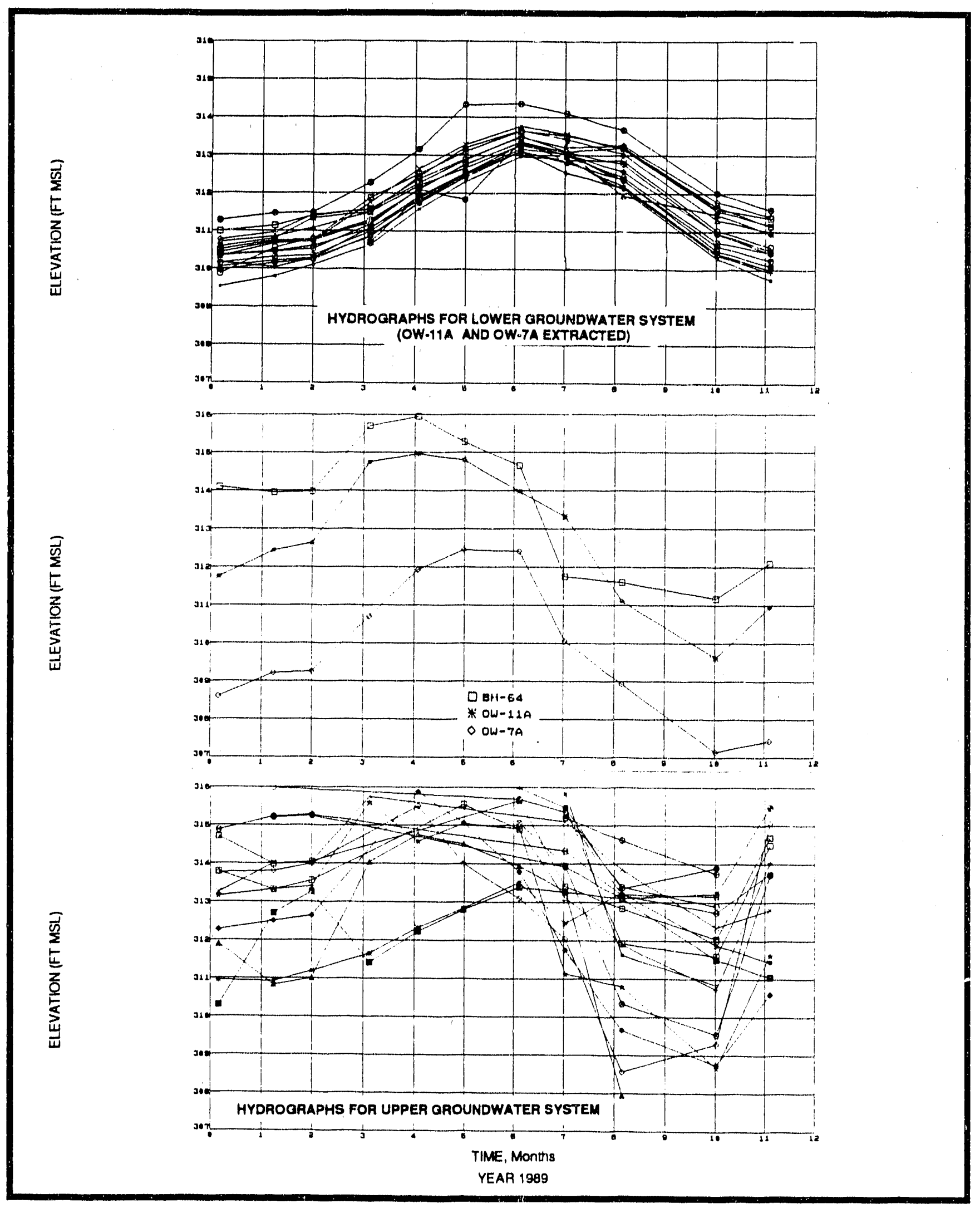

FIGURE 1-20 COMPARISON HYDROGRAPHS FOR WELLS OW-11A, OW-7A, AND BH-64 


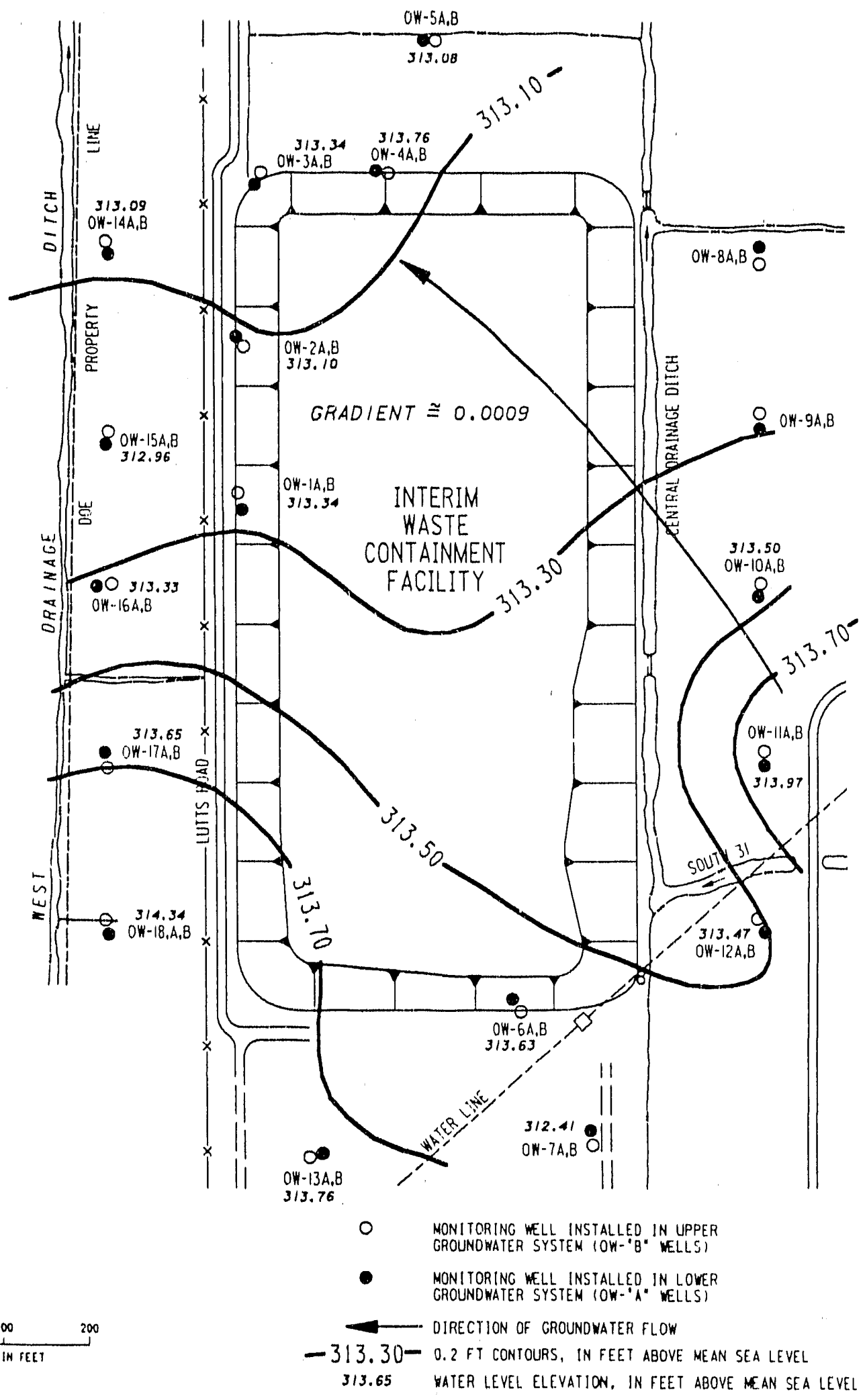

FIGURE 1-21 POTENTIOMETRIC MAP OF LOWER GROUNDWATER SYSTEM $(7 / 5 / 89)$ 


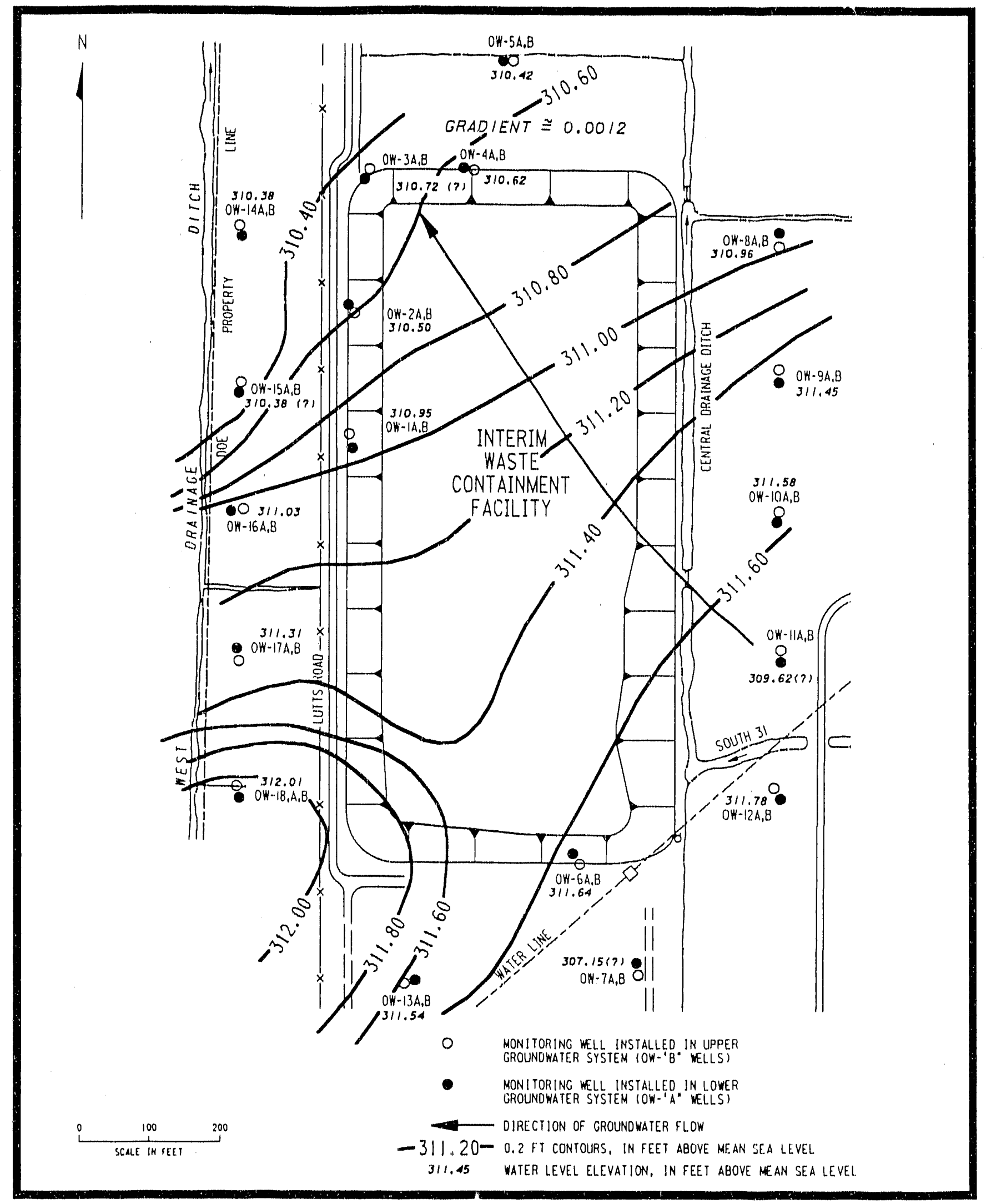

\section{FIGURE 1-22 POTENTIOMETRIC MAP OF LOWER GROUNDWATER SYSTEM (11/1/89)}


Figures $1-21$ and $1-22$ show a generalized flow direction from southeast to northwest, with a gradient of approximately 0.001 . Seasonal variations in gradient or flow direction are not evident.

\subsubsection{Bedrock Groundwater System}

The bedrock groundwater system occurs in the Queenston formation, located more than $13.7 \mathrm{~m} \mathrm{(45} \mathrm{ft)} \mathrm{below} \mathrm{ground} \mathrm{surface}$ at the site. The Queenston formation consists of shales, siltstone, and mudstone, and is slightly to moderately weathered along its upper surface (Ref. 2). The hydrographs for bedrock wells monitored in 1989 (Figure 1-23) are similar to those in previous years; direction and magnitude of gradient remain unchanged, on the order of 0.001 to the west-northwest.

Because the lower and bedrock systems are in hydraulic connection, the wells in the bedrock system show the same seasonal variation in water levels as those in the lower system, with highest levels in the summer and lowest in the winter.

\subsubsection{Conclusions}

- The upper groundwater system displays highest water level elevations in the spring and lowest elevations in the fall. The lower and bedrock groundwater systems monitored at the site display highest water level elevations in the summer and lowest elevations in the winter.

- The upper groundwater system occurs from 1.5 to $8.5 \mathrm{~m}$ (5 to $28 \mathrm{ft}$ ) below the ground surface in discontinuous media.

- The lower groundwater system occurs from 10.7 to $12.2 \mathrm{~m}$ (35 to $40 \mathrm{ft}$ ) below the ground surface in a mostly continuous silt and sand layer, and is confined by a gray clay unit 3.4 to $8.9 \mathrm{~m}$ (11 to $29 \mathrm{ft}$ ) thick. The lower system has a year-round direction of flow from the east to the northwest, and a gradient of approximately 0.001 . 


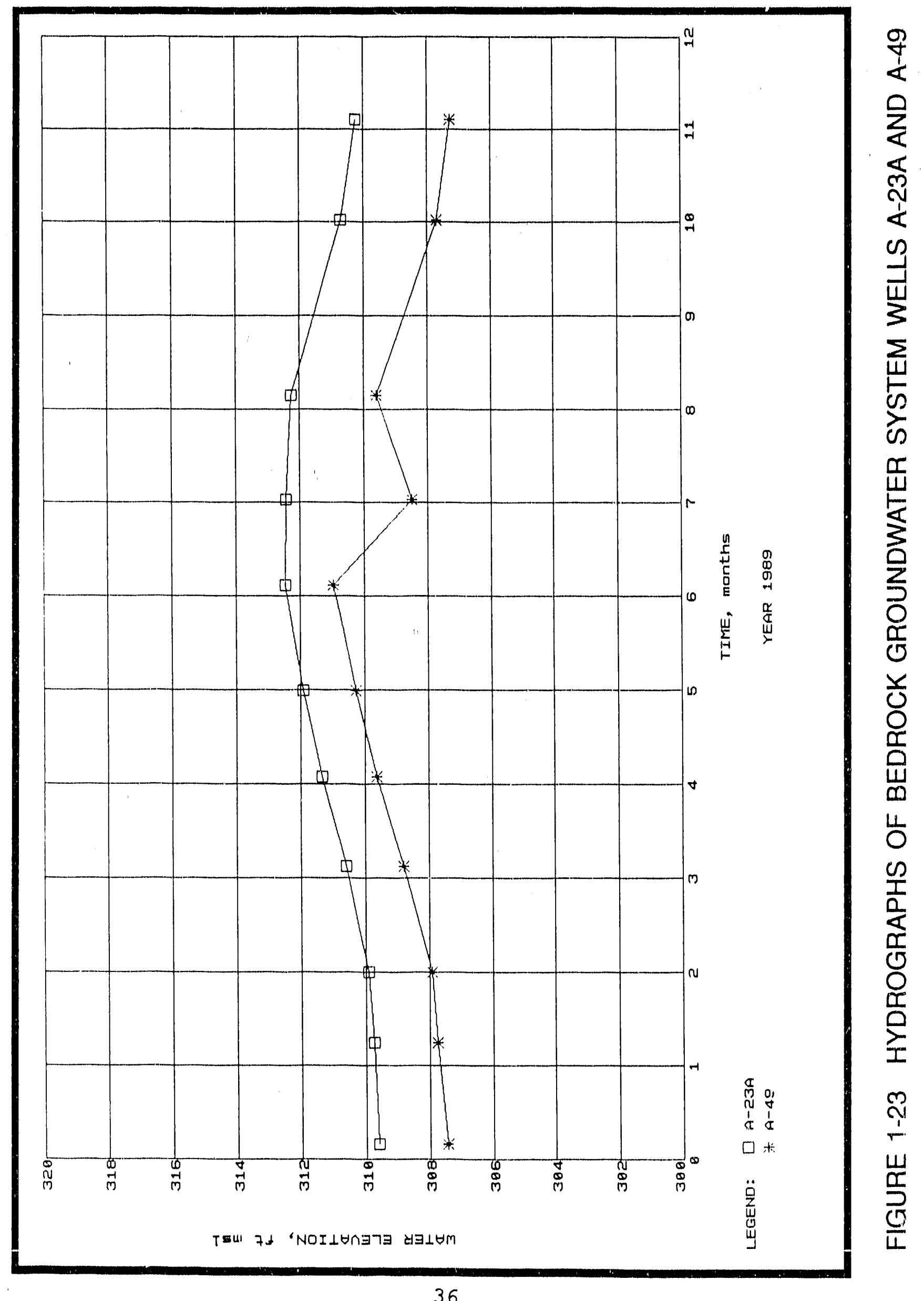


- The bedrock groundwater system occurs in the upper part of the Queenston formation, located $13.7 \mathrm{~m}$ or more (45 ft or more) below the site. The gradient and direction of flow are unchanged from previous years.

- Hydrographs of wells OW-7A, OW-11A, and $B H-64$ in the lower groundwater system show potentiometrio surface elevations similar to those shown on hydrographs of wells in the upper groundwater system. Some communication between the two systems may exist in the vicinity of these wells. 


\subsection{SUMMARY OF MONITORING RESULTS}

The environmental monitoring prograin, which began in 1981 , continued in 1989. Air, water, and sediments were sampled, and gamma radiation levels were monitored to verlfy compliance with the DOE radiation protection standard of $100 \mathrm{mrem} / \mathrm{yr}$ (Ref. 17). The potential radiation dose that might be received by a hypothetical maximally exposed individual was estimated to determine whether the site remains in compliance with the radiation protection standard.

Annual average radon concentrations (including background) at all monitoring stations were within the normal varlation associated with background measurements for this area (see Subsection 3,1). The average background concentrations of radon ranged from 4 to $14 \times 10^{-10} \mu \mathrm{Cl} / \mathrm{ml}$ ( 0.4 to $\left.1.4 \mathrm{pCl} / \mathrm{L}\right)$. Radon concentrations have remained stable at approximately background levels since 1986 (see Subsection 3.7.1) (Refs. 7-13).

Annual average gamma radiation levels recorded at the NFSS boundary ranged from background levels to $8 \mathrm{mrem} / \mathrm{yr}$ above background. These levels may be compared with naturally occurring background radiation levels in the vicinity of NFSS, which averaged $77 \mathrm{mrem} / \mathrm{yr}$ in 1989. External gamma radiation levels are discussed in subsection 3.2. Annual average radiation levels generally have decreased since 1985 (see Subsection 3.7.2) (Refs. 10-13).

In surface waters (Subsection 3.3), annual average concentrations of total uranium ranged from $4 \times 10^{-9}$ to $2.1 \times 10^{-8} \mu \mathrm{Ci} / \mathrm{ml}$ ( 4 to $21 \mathrm{pCi} / \mathrm{I}_{1}$ ); radium-226 concentrations ranged from $5 \times 10^{-10}$ to $2.5 \times 10^{-9} \mu \mathrm{Ci} / \mathrm{ml}(0.5$ to $2.5 \mathrm{pCi} / \mathrm{L})$. Average concentrations of both total uranium and radium-226 have decreased since 1985 (see Subsection 3.7.3) (Refs, 10-13).

In groundwater (Subsection 3.4), the highest annual average concentration of total uranium in an on-site well was $6.7 \times 10^{-6} \mu \mathrm{Cl} / \mathrm{ml}(67 \mathrm{pCj} / \mathrm{L})$, measured in well $\mathrm{A}-42$. Well $\mathrm{A}-42$ is located in a sand lens of unknown extent. Discussion of results of a December 1988 investigation of well A-42 is provided in 
Subsection 3.4. For radium-226, the maximum annual average concentration in an on-site well was $7 \times 10^{-10} \mu \mathrm{Cl} / \mathrm{ml}(0.7 \mathrm{pCl} / \mathrm{L})$, measured in well BH-48. From 1984 through 1989 , concentrations of total uranlum and radium-226 have remalned basloally stable (see Subsection 3.7.4) (Refs.9-13). In groundwater from wells surrounding the IWCF, the hichest annual average concentrations of total uranium and radium-226 lere $3.2 \times 10^{-8} \mu \mathrm{Cl} / \mathrm{ml}(32 \mathrm{pCl} / \mathrm{L})$ and $1 \times 10^{-9} \mu \mathrm{Cl} / \mathrm{ml}(1.0 \mathrm{pCl} / \mathrm{L})$, respectively. Concentrations of radionuclides in surface water and groundwater at NFSS are within DOE derived concentration guidelines.

Chemical analyses of groundwater revealed the presence of 16 metals. Twelve of these metals were detected in an upgradient well, which is indicative of the typically low-quality groundwater found in industrial urban areas.

In stream sediments (Subsection 3.5), the highest annual average concentration was $8.8 \mathrm{pCi} / \mathrm{g}$ for total uranium and $1.8 \mathrm{pCi} / \mathrm{g}$ for radium-226. Though DOE currently does not have guidelines for radioactivity levels in sediments, these concentrations are within DOE guidelines for soils.

Calculations were made of the potential radiological dose recelved by a hypothetical maximally exposed individual (Subsection 3.6.1). This hypothetical individual is one who is assumed to be adjacent to the site and who, when all potential routes of exposure are considered, receives the greatest dose. Evaluation of monitoring results indicates that exposure to external gamma radiation represents the only plausible route of public exposure. Accordingly, this pathway was the only one quantified.

The exposure to the hypothetical maximally exposed individual from external gamma radiation was $2 \mathrm{mrem} / \mathrm{yr}$ above background. This exposure is approximately equivalent to 2 percent of the DOE radiation protection standara.

The cumulative dose to the population within an $80-\mathrm{km}$ (50-mi) radius of NFSS that results from radioactive materials present at the site is indistinguishable from the dose that the same population recelves from naturally occurring radioactive sources. 


\subsection{DATA COLLECTION, ANALYSIS, NND EVALUATION}

This section provides the results of 1989 environmental monitoring at NFSS. A description is also given of the sampling, monitoring, and analytical procedures used. Caloulations were made to estimate the maximum possible radiation dose based on environmental conditions, measurements recorded, and evaluation of potential exposure pathways.

Data are presented in summary tables that include number of data polnts collected, and minimum, maximum, and average values. Individual sources of error (e.g., analytical error or sampling error) were not estimated. The "less than" notation (<) is used to denote specific sample analysis results that are below the limit of sensitivity of the analytical method, based on a statistical analysis of parameters. When computing annual averages, quarterly values reported as less than a given limit of sensitivity (detection limit) are considered equal to that limit of sensitivity. In previous environmental monitoring reports, when two or more such values were involved in calculating an annual average, the reported value carrled the "less than" notation. This year, because limits of sensitivity varied from quarter to quarter, an increasing number of results are at or below the limit of sensitivity, and because data error terms are not reported, a more conservative method of computing annual averages is being employed. Annual averages carry the "less than" notation only if all of the quarterly values involved in the calculation were less than the limit of sensitivity.

During 1989, the routine environmental monitoring program for NFSS included on-site and off-site radon monitoring, external gamma radiation measurements, and measurement of radionuclide concentrations in surface water, sediment, and groundwater. In addition, several nonradiological parameters were measured in. groundwater.

Trend tables are provided for radon and external gamma radiation levels and for radionuclides measured in surface water 
and groundwater. These tables ilst annual averages for each monitoring location for 1985 through 1789 to allow for comparisons of data and ldentification of trends in monitoring results (see subsection 3.7 ).

\subsection{RADON MONITORING}

Forty-seven radon detectors are maintained on the site and at site boundary stations, with three of the detectors (stations 31, 32, and 33) designated as quality controls. Three off-site detectors are maintained to measure the natural background level: station 30 , at $6.4 \mathrm{~km}(4 \mathrm{mi})$ west-southwest; station 120 , at $1.6 \mathrm{~km}$ ( $1 \mathrm{ml}$ ) southwest; and station 121 , at $1.6 \mathrm{~km}(1 \mathrm{ml})$ south. Detectors are placed along the site boundary at intervals designed to ensure adequate detection capability under most atmospheric conditions. Detectors are more closely spaced along the perimeter of the IWCF, where the potential for release of contaminants is greater. In April 1987, monitoring stations 13, 14, 15, and 29 were moved approximately $220 \mathrm{~m}(240 \mathrm{yd})$ eastward to make them more accessible and thereby facilitate routine exchange of detectors. Locations of radon monitors are shown in Figure 3-1.

Radon concentrations are determined using monitors purchased from the Terradex Corporation. These devices (Terradex Type F Track-Etch) consist of an alpha-sensitive film contained in a small plastic cup covered by a membrane through which radon can diffuse. Radon will diffuse through the membrane (in or out of the cup) when a concentration gradient exists; therefore, it will equilibrate with radon in the outside air. Alpha partioles from the radioactive decay of radon and its daughters in the cup create tiny tracks when they collide with the film. When returned to Terradex for processing, the flims are placed in a caustic etching solution to enlarge the tracks. Undex strong magnification, the tracks can be counted. The number of tracks per unit area (i.e., tracks/mm ${ }^{2}$ ) is related through calibration to the concentration of radon in alr. 


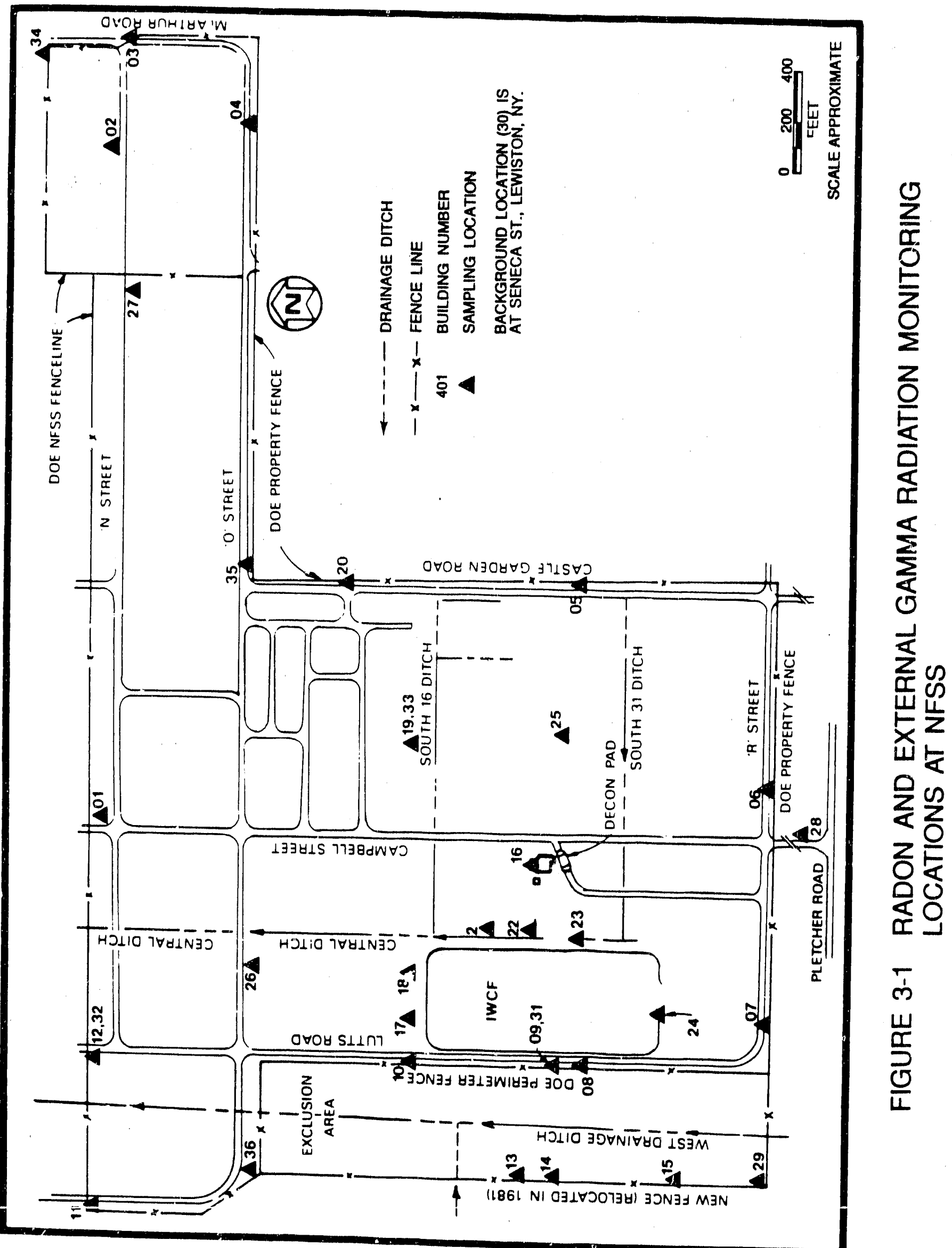


Fresh Track-Etch monitors are obtained from Terradex each quarter. Site personnel place these units in each sampling location and return the exposed monicors to Terradex for analysis.

Table 3-1 shows radon concentrations (including background) measured in the air at site boundary monitoring stations and the background stations. Annual average concentrations at the site boundary ranged from $4 \times 10^{-10}$ to $8 \times 10^{-10} \mu \mathrm{Ci} / \mathrm{ml}$ ( 0.4 to $0.8 \mathrm{pCi} / \mathrm{L})$. The annual average background measurements ranged from $4 \times 10^{-10}$ to $1.4 \times 10^{-9} \mu \mathrm{Ci} / \mathrm{ml}(0.4$ to $1.4 \mathrm{pCi} / \mathrm{L})$. The validity of the single highest reading of $3.8 \mathrm{pci} / \mathrm{L}$ at background station 30 is suspect; the other three 1989 measurements at this station were all less than $1.0 \mathrm{pCi} / \mathrm{L}$. For a comparison of radon concentrations measured from 1985 through 1989, see subsection 3.6.1.

Because of the nature of the radon source (i.e., large surface areas emanating radon at rates that vary widely with changes in climatic/atmospheric conditions), accurate determination of the annual radon release rate is not feasible. Measured radon concentrations at the site boundary and in the environs show that the on-site radon source makes a minimal contribution over natural radon concentrations in the area.

\subsection{EXTERNAL GAMIA RADIATION}

External gamma radiation levels were measlired at 47 monitoring stations; 17 of these are on the site boundary and 3 are on the perimeter of the former location of the tower that was used to store $\mathrm{K}-65$ residues. Three of the monitoring stations are off site to measure the background radiation level. In April 1987 , monitoring stations 13, 14, 15, and 29 were moved approximately $220 \mathrm{~m}(240 \mathrm{yd})$ eastward to make them more accessible for quarterly exchange of detectors. All locations correspond to the radon (Terradex) deteztor locations shown in Figure 3-1. The locations of the detectors are selected to ensure adequate measurement of radiation levels.

External gamma radiation levels are measured by lithium fluoride thermoluminescent dosimeters (TLDs). This system of measurement, used since 1988, utilizes tissue-equivalent 
TABLE 3-1

CONCENTRATIONS OF RADON-222

MEASURED BY TERRADEX MONITORS AT THE NFSS BOUNDARY, 1989

\begin{tabular}{|c|c|c|c|c|}
\hline \multirow{2}{*}{$\begin{array}{l}\text { Sampling } \\
\text { stationa }\end{array}$} & \multirow{2}{*}{$\begin{array}{c}\text { Number of } \\
\text { Samples }\end{array}$} & \multicolumn{2}{|c|}{ Concentration $\left(10^{-9}\right.$} & $\mu \mathrm{C} \dot{I} / \mathrm{ml}, \mathrm{b}, \mathrm{C}$ \\
\hline & & Minimum & Maximum & Averag \\
\hline 1 & 4 & 0.3 & 0.5 & 0.4 \\
\hline 3 & 4 & $<0.3$ & 0.6 & 0.4 \\
\hline 4 & 4 & $<0.3$ & 0.6 & 0.4 \\
\hline 5 & 4 & $<0.4$ & 1.6 & 0.7 \\
\hline 6 & 4 & $<0.3$ & 0.5 & 0.4 \\
\hline 7 & 4 & $<0.4$ & 2.0 & 0.8 \\
\hline 11 & 4 & $<0.3$ & 0.5 & 0.4 \\
\hline 12 & 4 & $<0.3$ & 0.8 & 0.5 \\
\hline 13 & 4 & $<0.4$ & 1.7 & 0.7 \\
\hline 14 & 3 & $<0.4$ & 0.6 & 0.5 \\
\hline 15 & 4 & $<0.3$ & 0.7 & 0.4 \\
\hline 20 & 4 & $<0.3$ & 0.4 & 0.4 \\
\hline 28 & 4 & 0.3 & 1.0 & 0.5 \\
\hline 29 & 4 & 0.4 & 1.9 & 0.8 \\
\hline $32^{d}$ & 4 & 0.4 & 1.3 & 0.6 \\
\hline 34 & 4 & $<0.3$ & 0.8 & 0.5 \\
\hline 35 & 4 & $<0.3$ & 0.4 & 0.4 \\
\hline 36 & 4 & 0.3 & 0.6 & 0.4 \\
\hline
\end{tabular}

\section{Backaround}

\begin{tabular}{|c|c|c|c|c|}
\hline $\begin{array}{r}30^{\mathrm{e}} \\
120^{\mathrm{f}} \\
1219\end{array}$ & $\begin{array}{l}4 \\
4 \\
4\end{array}$ & $\begin{array}{r}0.3 \\
<0.4 \\
<0.3\end{array}$ & $\begin{array}{l}3.8 \\
0.7 \\
0.5\end{array}$ & $\begin{array}{l}1.4 \\
0.5 \\
0.4\end{array}$ \\
\hline
\end{tabular}

a Locations of sampling stations are shown in Figure 3-1.

$\mathrm{b}_{1} \times 10^{-9} \mu \mathrm{Ci} / \mathrm{ml}$ is equivalent to $1 \mathrm{pCi} / \mathrm{L}$.

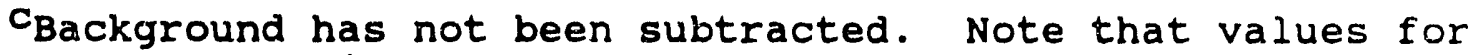
several stations are below background levels.

$d_{\text {station }} 32$ is a quality control for station 12 .

eBackground sampling station, located at seneca st.,

Lewiston, NY, approximately $6.4 \mathrm{~km}(4 \mathrm{mi})$ southwest of NFSS.

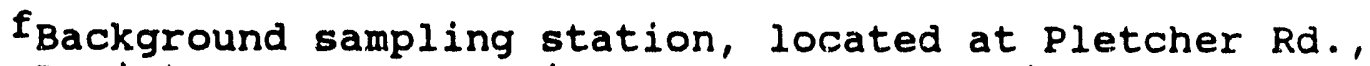

Lewiston, NY, approximately $1.6 \mathrm{~km}$ (1 $\mathrm{mi})$ southwest of NFSS.

Gackground sampling station, located at the intersection of Route 104 and Swain Rd., Lewiston, NY, approximately $1.6 \mathrm{~km}$ (1 mi) south of Niss. 
dosimeters to provide values that are more realistic in terms of radiation dose to tissues of the body at a depth of $1 \mathrm{~cm}$. Each monitoring station contains a minimum of four dosimeters, which are exchanged after approximately one year of accumulated exposure.

For example, a dosimeter placed in a station in October 1988 would be removed in october 1989 and replaced with a new dosimeter. Each dosimeter contains five individual lithium fluoride chips (each group of five chips preselected on the basis of having a reproducibility of \pm 3 percent across a series of laboratory exposures), the responses of which are averaged. Analysis is performed by Thermo Analytical/Eberline (TMA/E). The average value is then corrected for the shielding effect of the shelter housing (approximately 8 percent). The corrected value is then converted to millirem per year by dividing by the number of days of exposure and subsequently multiplying by 365 days.

Although the tissue-equivalent TLDs used are "state-of-theart," one should keep in mind when examining the external gamma radiation results that the dosimeter accuracy is approximately \pm 10 percent at levels from $100 \mathrm{mrem} / \mathrm{yr}$ to $1 \mathrm{rem} / \mathrm{yr}$ and \pm 25 percent at radiation levels around $70 \mathrm{mrem} / \mathrm{yr}$.

Monitoring results for the 17 site boundary stations, the 3 background stations, and the quality control station are presented in Table 3-2. For each quarter, an average of the background levels measured was subtracted from the site boundary measurements to provide an estimate of radiation levels resulting from residual materials at the site. The highest level was measured at a station adjacent to a sanitary landfill to which access is controlled by the owner. At this station, the maximum annual average level was $8 \mathrm{mrem} / \mathrm{yr}$ above the average background level of $77 \mathrm{mrem} / \mathrm{yr}$. Based on a very conservative $40-\mathrm{h} /$ week occupancy factor, the maximum exposure to workers in this area of the landfill would be $2 \mathrm{mrem} / \mathrm{yr}$.

In April 1988, two additional background stations were established at the Lewiston Town Hall and the Lewiston water pollution Control center. Because of the measurement system operating parameters, data from the new stations were not available for the first quarter of 1989. Background value for first quarter 
TABLE 3-2

EXTERNAL GAMMA RADIATION LEVELS AT NFSS, 1989

\begin{tabular}{lll}
\hline Sampling & $\begin{array}{c}\text { Number of } \\
\text { Measurements }\end{array}$ & $\begin{array}{l}\text { Radiation Level (mrem/yr) } b \\
\text { Minimum Maximum Average }\end{array}$ \\
\hline
\end{tabular}

\section{Site Boundary}

\begin{tabular}{|c|c|c|c|c|}
\hline 1 & 4 & $-c$ & $-c$ & $-c$ \\
\hline 3 & 4 & $-c$ & $-c$ & $-C$ \\
\hline 4 & 4 & $-C$ & 1 & $-c$ \\
\hline 5 & 4 & $-C$ & 7 & 2 \\
\hline 6 & 4 & $-c$ & $-c$ & $-c$ \\
\hline 7 & 4 & $-C$ & 8 & 2 \\
\hline 11 & 4 & $-C$ & $-C$ & $-C$ \\
\hline 12 & 4 & $-c$ & $-C$ & $-C$ \\
\hline 13 & 4 & $-C$ & 5 & 1 \\
\hline 14 & 4 & $-C$ & $-C$ & $-c$ \\
\hline 15 & 4 & $-C$ & 8 & 3 \\
\hline 20 & 4 & 5 & 13 & 8 \\
\hline 28 & 4 & $-c$ & 10 & 2 \\
\hline 29 & 4 & $-c$ & $-c$ & $-C$ \\
\hline $32^{d}$ & 4 & $-C$ & 1 & $-C$ \\
\hline 34 & 4 & $-C$ & $-c$ & $-C$ \\
\hline 35 & 4 & $-C$ & 3 & 1 \\
\hline 36 & 4 & $-C$ & 1 & $-c$ \\
\hline
\end{tabular}

Background

$\begin{array}{rllll}30 \mathrm{e} & 4 & 54 & 70 & 61 \\ 120^{\mathrm{f}} & 3 & 80 & 87 & 83 \\ 1219 & 3 & 84 & 90 & 87\end{array}$

alocations of sampling stations are shown in Figure 3-1.

$b_{\text {Average of measured backgrounds has been subtracted from }}$ measurements taken at site boundary locations.

"Measurement was less than or equal to the measured background value.

dstation 32 is a quality control for station 12 .

elocated at Seneca St., Lewiston, NY, approximately $6.4 \mathrm{~km}(4 \mathrm{mi})$ southwest of NFSS.

flocated at Pletcher Rd., Seneca, NY, approximately $1.6 \mathrm{~km}$ ( $1 \mathrm{mi}$ ) south of NFSS; first sampled in April 1989.

glocated at the intersection of Route 104 and Swain Rd., Lewiston, NY, approximately $1.6 \mathrm{~km}$ (1 $\mathrm{mi})$ west of NFSS; first sampled in April 1989. 
comes solely from station 30 at seneca street, Lewiston, New York. Data for the other quarters were obtained from all three background stations.

The background external gamma radiation value for a given station is not constant. Because the background value is a combination of both natural terrestrial sources and cosmic radiation sources, factors such as the location of the detector in relation to surface rock outcrops, stone or concrete structures, or highly mineralized soil can affect the value measured. Independent of the placement of the detector at the site are the factors of site altitude, annual barometric pressure cycles, and the occurrence and frequency of solar flare activity (Ref. 18).

Because of these factors, the background radiation level is not constant from one location to another even over a short time. Thus it is not abnormal for stations at the boundary of a site to have an external gamma radiation value less than the background level measured distance from the site.

For comparisons of external gamma radiation levels measured from 1985 through 1989, see Subsection 3.7.2.

\subsection{SURFACE WATER SAMPLING}

During 1989, sampling was performed to determine the concentrations of total uranium and radium in surface water and groundwater at on-site and off-site locations. On-site sampling locations for surface water are shown in Figure 3-2, and off-site locations are shown in Figure 3-3. Samples were collected quarterly at locations 9, 10, 11, 12, and 20. Locations 12 and 20 are 1.6 and $3.2 \mathrm{~km}$ ( $1 \mathrm{mi}$ and $2 \mathrm{mi}$ ) downstream, respectively, of the northern boundary of NFSS. Location 9 is a background location established at the South 31 Ditch in october 1988. Locations 10 and 11 are in the Central Drainage Ditch.

Surface water collection locations were selected on the basis of potential for contaminant migration and discharge routes from the site. Because surface water runoff from the site discharges via the Central Drainage Ditch, all sampling locations except location 9 were placed along the ditch. 


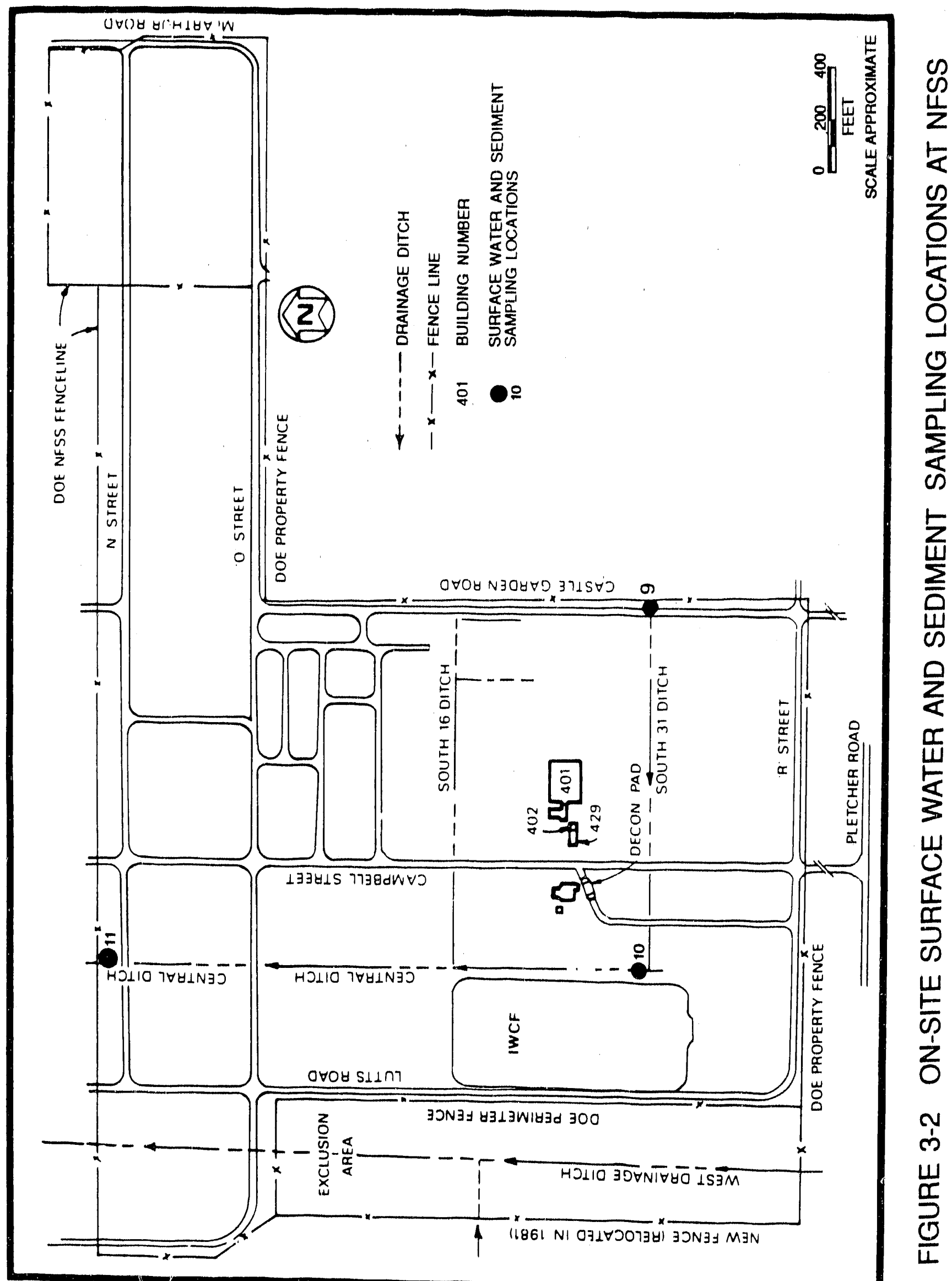




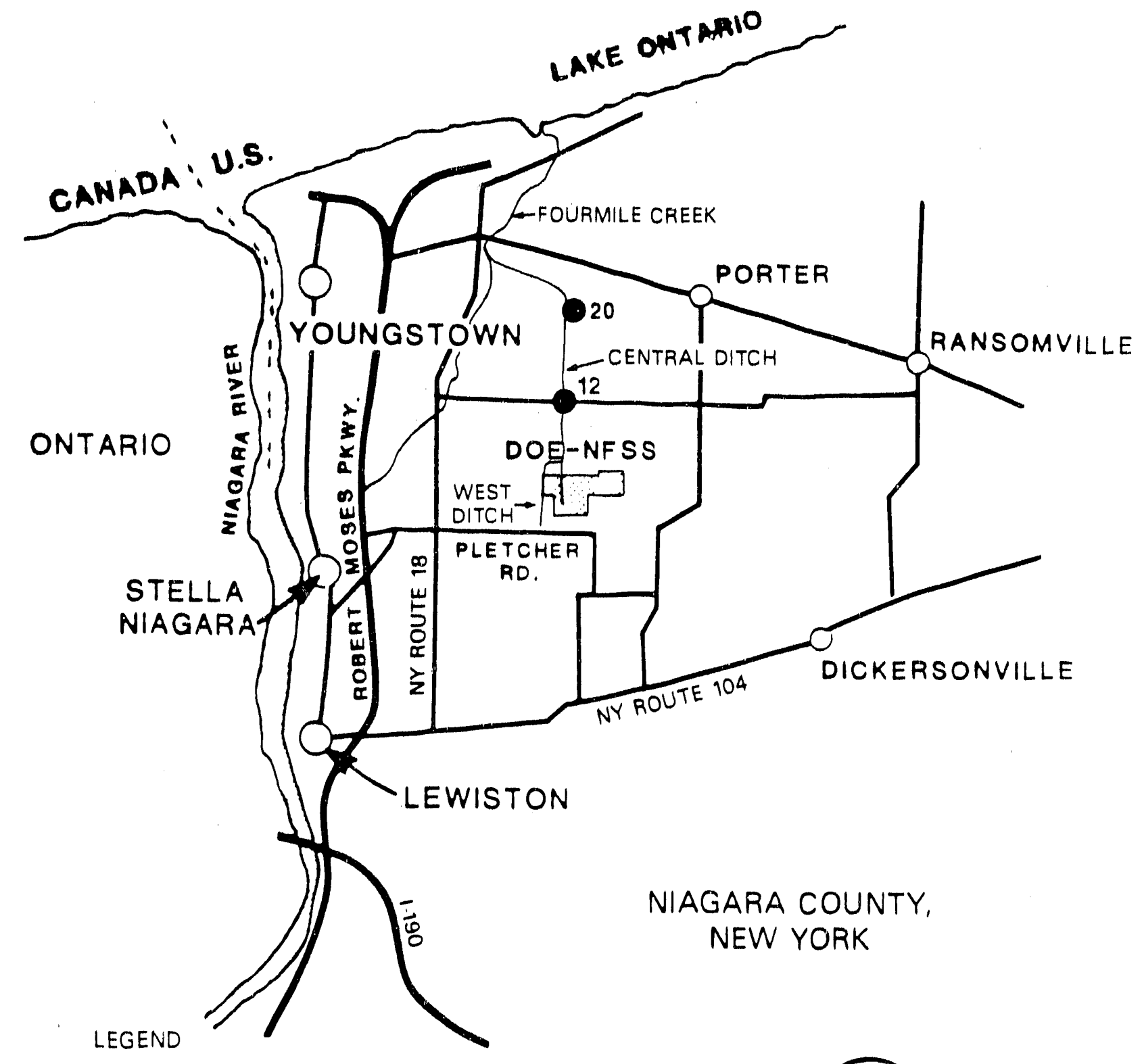

12,20 SURFACE WATER AND SEDIMENT SAMPLING LOCATIONS IN CENTRAL DITCH

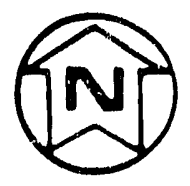

DRAWING NOT TO SCALE

FIGURE 3-3 OFF-SITE SURFACE WATER AND SEDIMENT SAMPLING LOCATIONS IN THE VICINITY OF NFSS 
Nominal 1-L (0.26-gal) grab samples were collected to fill a 3.8-I (1.0-gal) container and were analyzed by TMA/E. The concentration of total uranium was determined by a fluorometric method. Radium-226 concentrations in water were determined by radon emanation. (This method consists of precipitating radium as sulfate and transferring the treated sulfate to a radon bubbler, where radon-222 is allowed to come to equilibrium with its radium-226 parent. The radon-222 is then withdrawn into a scintillation cell and counted by the gross alpha technique. The quantity of radon-222 detected in this manner is directly proportional to the quantity of radium-226 originally present in the sample.)

Results of analyses of surface water for total uranium content are given in Table 3-3; radium-226 results are given in Table $3-4$. Annual average total uranium concentrations in on-site surface water ranged from 1.6 to $2.1 \times 10^{-8} \mu \mathrm{Ci} / \mathrm{ml}(16$ to $21 \mathrm{pCi} / \mathrm{L}) ;$ in off-site surface water, concentrations ranged from $4 \times 10^{-9}$ to $1 \times 10^{-8} \mu \mathrm{Ci} / \mathrm{ml}$ ( 4 to $10 \mathrm{pCi} / \mathrm{L}$ ). The highest annual average concentration of radium-226 in surface water was $2.5 \times 10^{-9} \mu \mathrm{Ci} / \mathrm{ml}(2.5 \mathrm{pci} / \mathrm{L})$. Radionuclide concentrations in surface water are well within DOE derived concentration guidelines and off-site sampling locations approximate background levels.

Sampling of water supplied by a local municipal water system was suspended in 1986. This system draws water from the upper Niagara River approximately $16 \mathrm{~km}(10 \mathrm{mi})$ south of NFSS. Sampling was suspended because the draw point of the system was upstream of NFSS and because data from previous years indicated no total uranium or radium-226 concentrations discernibly different from background levels in these waters.

For comparisons of radionuclide concentrations in surface water measured at the site from 1985 through 1989, see subsection 3.7 .3 .

\subsection{GROUNDWATER SAYIPLING}

During 1989, groundwater samples were collected quarterly from 42 on-site wells. Sampling locations were selected based on the 
TABLE 3-3

CONCENTRATIONS OF TOTAL URANIUM IN NFSS WATER SAMPLES, 1989

\begin{tabular}{lll}
\hline $\begin{array}{l}\text { Sampling } \\
\text { Location }\end{array}$ & $\begin{array}{l}\text { Number of } \\
\text { Samples }\end{array}$ & Concentration $\left(10^{-9} \mu C 1 / \mathrm{m} 1\right)^{b}$ \\
\hline
\end{tabular}

Surface Water

$\frac{\text { Qn site }}{10}$

11

off site

12

20
$3^{\mathrm{C}}$

$3^{C}$

$3 \mathrm{C}$

$3^{C}$

$3^{c}, d$
10

14

9

3

3

\section{6}

18

16

Background

9

Groundwatere

\begin{tabular}{c} 
On site \\
\hline$B H-5$ \\
$B H-48 f$ \\
$B H-619$ \\
$A-42$ \\
$A-5 D$ \\
$A-52$
\end{tabular}

4
4
4
4
4
4

$<3$

$<3$

$<3$

$<3$

$<3$

$<3$

$<18$
10
$<3$
100
13
21

7

5

$<3$

67

7

13

asampling locations are shown in Figures $3-2$ and $3-3$ (surfaye water) and 1-7 (groundwater).

$\mathrm{b}_{1} \times 10^{-9} \mu \mathrm{Ci} / \mathrm{ml}$ is equivalent to $1 \mathrm{pCi} / \mathrm{L}$.

chocation was frozen in the first quarter.

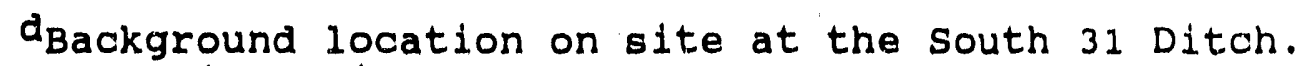
Established in October 1988.

ewells with the prefix "A" are in the upper groundwater system; those with the prefix "BH" are in the lower groundwater system.

fupgradient well.

gowngradient well. 
TABLE 3-4

CONCENTRATIONS OF RADIUM-226 IN NFSS WATER SAMPLES, 1989

Sampling
Location $\quad \begin{gathered}\text { Number of } \\ \text { Samples }\end{gathered} \quad \frac{\text { Concentration }\left(10^{-} 9 \mu C \perp / m, L^{b}\right.}{\text { Minimum }}$

\section{Surface Water}

on site

10

11

off site

12

20 $3^{\circ}$

$3^{\mathrm{C}}$

0.2

0.2

0.3

0.6

0.9

4.8

0.6

2.5

1.2

0.6

0.8

0.5

Background

9

$3^{c, d}$

0.3

Groundwatere

\begin{tabular}{c} 
On Site \\
\hline$B H-5$ \\
$B H-48$ f \\
$B H-619$ \\
$A-42$ \\
$A-50$ \\
$A-52$
\end{tabular}

4

4

4

4

4

4

0.5

0.8

0.5

1.1

0.7

0.6
0.4

0.7

0.4

0.6

0.5

0.6

asampling locations are shown in Figures $3-2$ and $3-3$ (surface water) and 1-7 (groundwater).

$\mathrm{b}_{1} \times 10^{-9} \mu \mathrm{Cl} / \mathrm{ml}$ is equivalent to $1 \mathrm{pCl} / \mathrm{L}$.

Clocation was frozen in the first quarter.

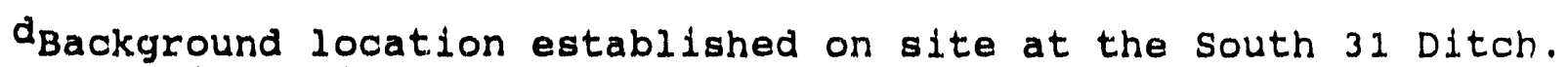
Established in October 1988.

ewells with the prefix "A" are in the upper groundwater system; those with the preflx "BH" are in the lower groundwater system.

fupgradient well.

gowngradient well. 
Inventory of radioactive materlals in varlous areas of the site and avallable hydrogeological data. Most of the monitoring wells are located near the IWCF. Other wells are located both upgradient and downgradient to provide background data and to monitor any migration of contaminants of site in the upper and lower groundwater systems. In late 1986, 36 wells ("Ow" wells in Figure 1-7) were installed along the IWCF perimeter to monitor its performance. These wells were added to the environmental monitoring program in April 1987.

Wells $\mathrm{BH}-5$ and $\mathrm{BH}-48$ also monitor the lower groundwater system. Six on-site wells--BH-49, $\mathrm{BH}-51, \mathrm{BH}-63, \mathrm{BH}-64, \mathrm{BH}-70$, and $\mathrm{BH}-71$ in the lower groundwater system-were monltored from 1983 through 1988 and then dropped from the program in January 1989. All parameters measured in these wells were consistently at or very close to background levels. Measurements for these wells are listed in Refs. 8 through 13.

Wells $A-42, A-50$, and $A-52$ also monitor the upper groundwater system around the IWCF (but are not among the 36 new wells). Well A-42 is drilled into a sand lens of unknown extent. The chemical, radiological, and hydrogeological behavior of this well was investigated in December 1988. Results indicate that the sand lens into which this well is completed is not in good hydraulic connection with the zones of completion in adjacent wells. Additionaliy, results of sequential sampling indicate that radioactive contamination in well $A-42$ may be associated with contaminated soils in or near the well.

Monitoring wells $\mathrm{BH}-48$ and $\mathrm{BH}-61$, which are installed in the lower groundwater system outside the IWCF area, represent upgradient and downgradient, respectively. Locations of these welis are shown in Figure $1-7$.

Groundwater samples were collected after the wells had been bailed dry and allowed to recover or three casing volumes had been removed and a 24 -h perlod had been allowed for well recharge. Nominal 1-L (0.26-gal) grab samples were collected with a bailer to fill a $3.8-1$ (1.0-gal) container. Using the analysis methods described for surface water, TMA/E analyzed the samples for 
dissolved total uranium and radium-226, and Weston Analytical Laboratory unalyzed samples for several chemical indicator parameters and heavy metals.

\subsubsection{Radiological}

Analytical results for total uranium conocntrations in groundwater are listed in Table $3-3$; radium results are given in Table 3-4. Table 3-5 gives results for total uranium in the monitoring wells along the perimeter of the IWCF; Table 3-6 gives the results for radium-226. innual averaye concentrations of total uranium in groundwater ranged from $<3 \times 10^{-9}$ to $6.7 \times 10^{-8} \mu \mathrm{Ci} / \mathrm{ml}$ $(<3$ to $67 \mathrm{pCl} / \mathrm{L})$. Annual average concentrations of radium-226 in groundwater ranged from 4 to $7 \times 10^{-10} \mu \mathrm{Cl} / \mathrm{ml}(0.4$ to $0.7 \mathrm{pCl} / \mathrm{L})$. Annual averages for total uranium in water in the wells monitoring the IWCF area ranged from $<3 \times 10^{-9}$ to $3.2 \times 10^{-8} \mu \mathrm{Cl} / \mathrm{ml}<<$ to $32 \mathrm{pCl} / \mathrm{L})$. Radium-226 annual average values for the area around IWCF ranged from $3.0 \times 10^{-10}$ to $1.0 \times 10^{-9} \mu \mathrm{Cl} / \mathrm{ml}$ $(0.3$ to $1.0 \mathrm{pCi} / \mathrm{L})$. These values are all kielow DOE derived concentration guidelines.

For a comparison of radionuclide concentrations measured in groundwater at NFSS from 1985 through 1989, see subsection 3.7.4.

\subsubsection{Chemical}

In April 1987, monitoring of the groundwater for chemical indicator parameters began at NFSS. These indicator parameters are pH, specific conductance, total organic carbon (TOC), and total organic halides (TOX). These parameters indicate changes in the Inorganic and organic composition of the groundwater.

specific conductance and $\mathrm{pH}$ measire changes in the inorganic composition of the groundwater. Acidity or basicity of water is expressed $\mathrm{pH}$. A change in $\mathrm{pH}$ affects the solubility and mobility of chemical contaminants in groundwater. Specific 
TABLE $3-5$

CONCENTRATIONS OF TOTAL URANIUM IN NFSS IWCF MONITORING WELLS, 1989

\begin{tabular}{|c|c|c|c|c|}
\hline \multirow{2}{*}{$\begin{array}{l}\text { Sampling } \\
\text { Location }\end{array}$} & \multirow{2}{*}{$\begin{array}{l}\text { Number of } \\
\text { Samples }\end{array}$} & \multicolumn{3}{|c|}{ concentration $\left(10^{-9} \mu \mathrm{cl} / \mathrm{m} 1\right)^{b}$} \\
\hline & & Minimum & Maximum & Average \\
\hline$O W-1 A$ & 4 & $<3$ & 5 & 4 \\
\hline$O W-1 B$ & 4 & $<3$ & 12 & 8 \\
\hline$O W-2 A$ & 4 & $<3$ & 5 & 4 \\
\hline$O W-2 B$ & 4 & 7 & 12 & 9 \\
\hline$O W-3 A$ & 4 & 5 & 10 & 8 \\
\hline$O W-3 B$ & 4 & 15 & 20 & 17 \\
\hline$O W-4 A$ & 4 & $<3$ & 3 & 3 \\
\hline$O W-4 B$ & 4 & $<3$ & 11 & 7 \\
\hline$O W-5 A$ & 4 & $<3$ & 4 & 4 \\
\hline$O W-5 B$ & 4 & 10 & 14 & 12 \\
\hline$O W-6 A$ & 4 & $<3$ & 3 & 3 \\
\hline$O W-6 B$ & 4 & 9 & 18 & 13 \\
\hline$O W-7 A$ & 4 & 9 & 12 & 10 \\
\hline$O W-7 B$ & 4 & $<3$ & 4 & 3 \\
\hline$O W-8 A$ & 4 & $<3$ & 9 & 5 \\
\hline$O W-8 B$ & 4 & 16 & 22 & 20 \\
\hline$O W-9 A$ & 4 & $<3$ & 10 & 5 \\
\hline$O W-9 B$ & $3^{c}$ & 13 & 25 & 20 \\
\hline$O W-10 A$ & 4 & $<3$ & $<3$ & $<3$ \\
\hline$O W-10 B$ & 4 & 3 & 12 & 7 \\
\hline$O W-11 A$ & 4 & 26 & 40 & 32 \\
\hline$O W-11 B$ & 4 & $<3$ & $<3$ & $<3$ \\
\hline$O W-12 A$ & 4 & $<3$ & 16 & 7 \\
\hline$O W-12 B$ & $3^{C}$ & 7 & 13 & 10 \\
\hline$O W-13 A$ & 4 & $<3$ & $<3$ & $<3$ \\
\hline$O W-13 B$ & 4 & $<3$ & 26 & 17 \\
\hline$O W-14 \mathrm{~A}$ & 4 & $<3$ & $<3$ & $<3$ \\
\hline$O W-14 \mathrm{~B}$ & 4 & $<3$ & 8 & 6 \\
\hline$O W-15 A$ & 4 & $<3$ & $<3$ & $<3$ \\
\hline$O W-15 B$ & 4 & 8 & 27 & 14 \\
\hline$O W-16 A$ & 4 & $<3$ & 3 & 3 \\
\hline OW- 16B & 4 & 4 & 21 & 11 \\
\hline$O W-17 A$ & 4 & $<3$ & 6 & 4 \\
\hline$O W-17 B$ & 4 & 5 & 12 & 8 \\
\hline$O W-18 A$ & 4 & $<3$ & 9 & 5 \\
\hline$O W-18 B$ & 4 & 8 & 26 & 19 \\
\hline
\end{tabular}

asampling locations are shown in Figure 1-7.

$b_{1} \times 10^{-9} \mu \mathrm{Cl} / \mathrm{ml}$ is equivalent to $1 \mathrm{pCl} / \mathrm{L}$.

CWell was dry in the fourth quarter. 
TABLE $3-6$

CONCENTRATIONS OF RADIUM-226 IN NFSS IWCF

MONITORING WELLS, 1989

\begin{tabular}{|c|c|c|c|c|}
\hline \multirow{2}{*}{$\begin{array}{l}\text { Sampling } \\
\text { Locationa }\end{array}$} & \multirow{2}{*}{$\begin{array}{c}\text { Number of } \\
\text { Samples }\end{array}$} & \multicolumn{2}{|c|}{ concentration $\left(10^{-9}\right.$} & \multirow{2}{*}{$\frac{\mu \mathrm{C} i / \mathrm{m} I)^{\mathrm{b}}}{\text { Average }}$} \\
\hline & & Minimum & Maximum & \\
\hline$O W-1 A$ & 4 & 0.3 & 1.4 & 0.6 \\
\hline$O W-1 B$ & 4 & 0.4 & 1.2 & 0.7 \\
\hline$O W-2 A$ & 4 & 0.1 & 0.7 & 0.4 \\
\hline$O W-2 B$ & 4 & 0.1 & 0.7 & 0.3 \\
\hline$O W=3 A$ & 4 & 0.4 & 1.0 & 0.5 \\
\hline$O W-3 B$ & 4 & 0.4 & 1.4 & 0.7 \\
\hline$O W-4 A$ & 4 & 0.3 & 1.0 & 0.5 \\
\hline$O W-4 B$ & 4 & 0.1 & 1.2 & 0.5 \\
\hline$O W-5 A$ & 4 & 0.2 & 0.8 & 0.4 \\
\hline$O W-5 B$ & 4 & 0.6 & 0.9 & 0.7 \\
\hline$O W-6 A$ & 4 & 0.3 & 0.9 & 0.5 \\
\hline$O W-6 B$ & 4 & 0.3 & 1.0 & 0.5 \\
\hline$O W-7 A$ & 4 & 0.8 & 1.4 & 1.0 \\
\hline$O W-7 B$ & 4 & 0.3 & 0.9 & 0.5 \\
\hline$O W-8 A$ & 4 & 0.4 & 1.0 & 0.6 \\
\hline$O W-8 B$ & 4 & 0.3 & 1.2 & 0.6 \\
\hline $0 W-9 A$ & 4 & 0.4 & 0.8 & 0.5 \\
\hline$O W-9 B$ & $3^{c}$ & 0.5 & 1.1 & 0.9 \\
\hline$O W-10 A$ & 4 & 0.2 & 0.6 & 0.4 \\
\hline$O W-10 B$ & 4 & 0.2 & 0.6 & 0.3 \\
\hline$O W-11 A$ & 4 & 0.4 & 1.3 & 0.8 \\
\hline$O W-11 B$ & 4 & 0.3 & 0.7 & 0.4 \\
\hline$O W-12 A$ & 4 & 0.4 & 0.6 & 0.5 \\
\hline$O W-12 B$ & $3^{c}$ & 0.4 & 0.7 & 0.5 \\
\hline$O W-13 A$ & 4 & 0.4 & 1.0 & 0.6 \\
\hline$O W-13 B$ & 4 & 0.4 & 1.3 & 0.7 \\
\hline$O W-14 \mathrm{~A}$ & 4 & 0.2 & 0.4 & 0.3 \\
\hline$O W-14 B$ & 4 & 0.2 & 3.0 & 1.0 \\
\hline$O W-15 A$ & 4 & 0.3 & 0.5 & 0.4 \\
\hline$O W-15 B$ & 4 & 0.2 & 2.4 & 0.8 \\
\hline$O W-.16 \mathrm{~A}$ & 4 & 0.3 & 1.0 & 0.5 \\
\hline$O W-16 B$ & 4 & 0.3 & 1.6 & 0.7 \\
\hline$O W-17 A$ & 4 & 0.2 & 0.4 & 0.3 \\
\hline$O W-17 B$ & 4 & 0.2 & 0.6 & 0.4 \\
\hline$O W-18 \mathrm{~A}$ & 4 & 0.2 & 0.5 & 0.3 \\
\hline OW-18B & 4 & 0.4 & 2.1 & 0.8 \\
\hline
\end{tabular}

asampling locations are shown in Figure 1-7.

$b_{1} \times 10^{-9} \mu \mathrm{Ci} / \mathrm{ml}$ is equivalent to $1 \mathrm{pCi} / \mathrm{L}$.

CWell was dry in the fourth quarter. 
conductance measures the capacity of water to conduct an electrical current. Generally, conductivity increases with an elevated concentration of dissolved solids. Waters with high salinities or high total aissolved solids exhibit high conductivities.

Groundwater is analyzed for TOC and Tox to determine organic content. TOC measures the total organic carbon content of water but is not specific to a given compound. Tox measures organic compounds containing halogens because many pollutants contain halogenated hydrocarbons, which are organic compounds containing fluorine, chlorine, bromine, and iodine.

As shown in Table 3-7, $\mathrm{pH}$ varied from slightly acid to basic in wells across the site with the exception of wells OW-13A and $\mathrm{BH}-5$, where the $\mathrm{pH}$ remained quite basic throughout the year. Results for the other water quality parameters measured at these two wells were similar to results from upgradient well $\mathrm{BH}-48$.

TOC and TOX ranged from 1.3 to $129 \mathrm{mg} / \mathrm{L}$ and below detectable limits to $125 \mathrm{\mu g} / \mathrm{L}$, respectively. The data indicate relatively unchanged levels of TOC and TOX when compared with 1988 results (Ref. 13).

Specific conductance across the site varied from a low of 1,110 to a high of $4,720 \mu \mathrm{mhos} / \mathrm{cm}$. Analytical results indicate that the groundwater at NFSS is of poor quality, which is typical of groundwater in industrial urban areas.

Dissolved metals analyses were conducted on all the "OW" wells in addition to $\mathrm{A}-42, \mathrm{BH}-5, \mathrm{BH}-48$, and $\mathrm{BH}-61$. Results from the broad screen metals analyses performed on the January samples indicated that analyses performed on a smaller, key group of metals would be a safe and more cost-effective mode of monitoring metals in NFSs groundwater. For this reason, samples for April, Juiy, and october were analyzed for boron, aluminum, copper, iron, manganese, lead, mercury, and vanadium only. Levels recorded for the other metals presented in Table 3-8 represent single measurements.

Metal ions are normal constituents of groundwater resulting from the soil through which the groundwater flows. Metal ions can also be introduced as a result of previous waste management activities. Boron, calcium, iron, magnesium, manganese, sodium, 
TABLE 3-7

RANGES OF WATER QUALITY PARAMETERS IN GROUNDWATER

AT NFSS, 1989

Page 1 of 2

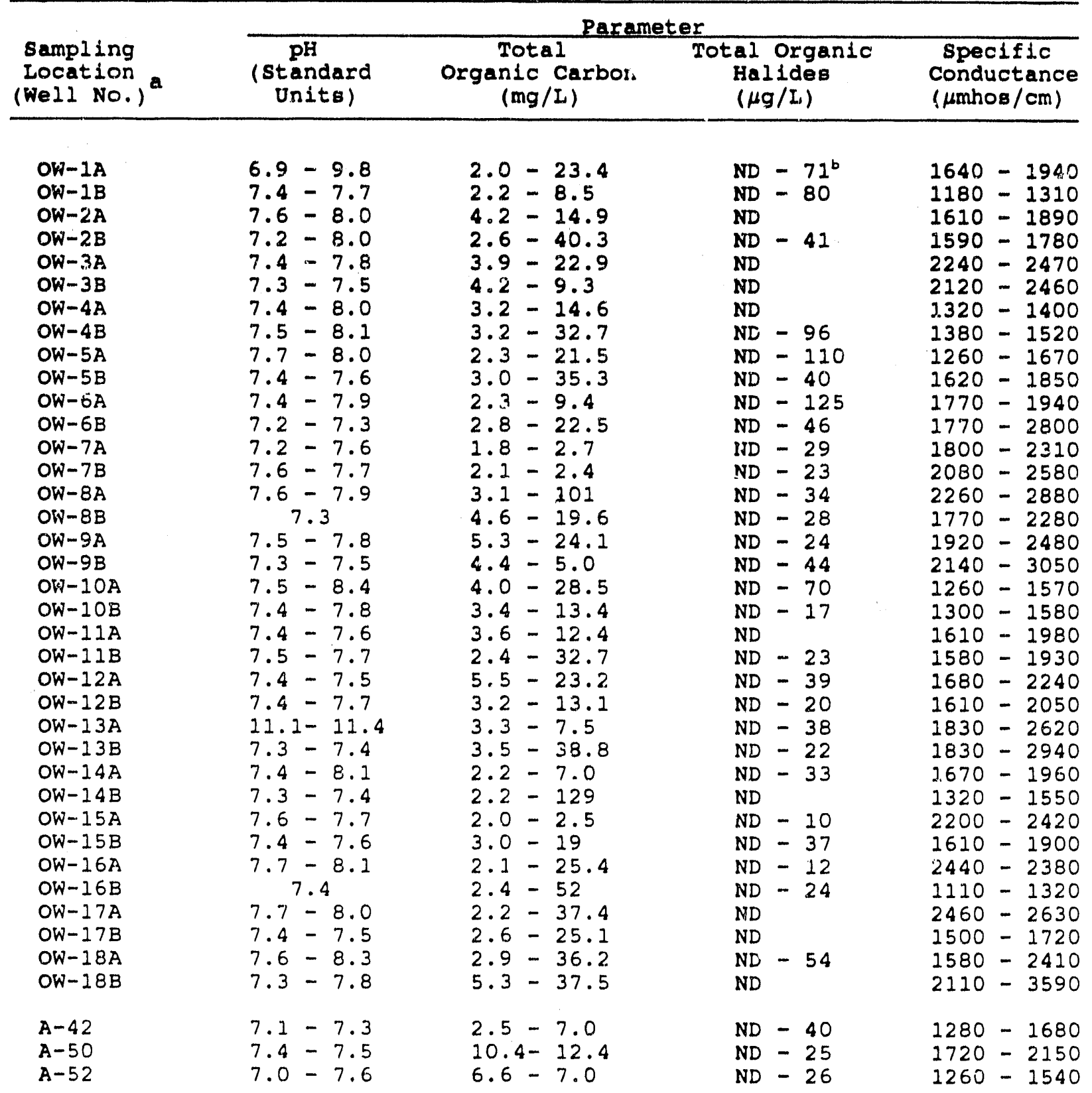


TABLE 3-7

(continued)

Page 2 of 2

\begin{tabular}{|c|c|c|c|c|}
\hline $\begin{array}{l}\text { Sampling } \\
\text { Location } \\
\text { (Well No.) }\end{array}$ & $\begin{array}{c}\mathrm{pH} \\
\text { (standard } \\
\text { Units) }\end{array}$ & $\begin{array}{c}\text { Total } \\
\text { Organic Carbon } \\
(\mathrm{mg} / \mathrm{L})\end{array}$ & $\begin{array}{c}\text { Total Organic } \\
\text { Hal dea } \\
(\mu g / L)\end{array}$ & $\begin{array}{l}\text { Specific } \\
\text { Conductance } \\
(\mu \mathrm{mhos} / \mathrm{cm})\end{array}$ \\
\hline $\begin{array}{l}\mathrm{BH}-5 \\
\mathrm{BH}-48^{\mathrm{C}} \\
\mathrm{BH}-61\end{array}$ & $\begin{aligned} 11.5 & =11.6 \\
7.4 & =7.9 \\
7.4 & =9.4\end{aligned}$ & $\begin{array}{l}6.2-7.6 \\
1.3-2.7 \\
2.9-7.0\end{array}$ & $\begin{array}{l}\text { ND } \\
\text { ND } \\
\text { ND }-85\end{array}$ & $\begin{array}{r}1200-1430 \\
3500-4720 \\
957-1400\end{array}$ \\
\hline
\end{tabular}

Monitoring well locations are shown in Figure 1-7.

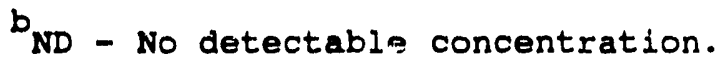

cupgradient well. 


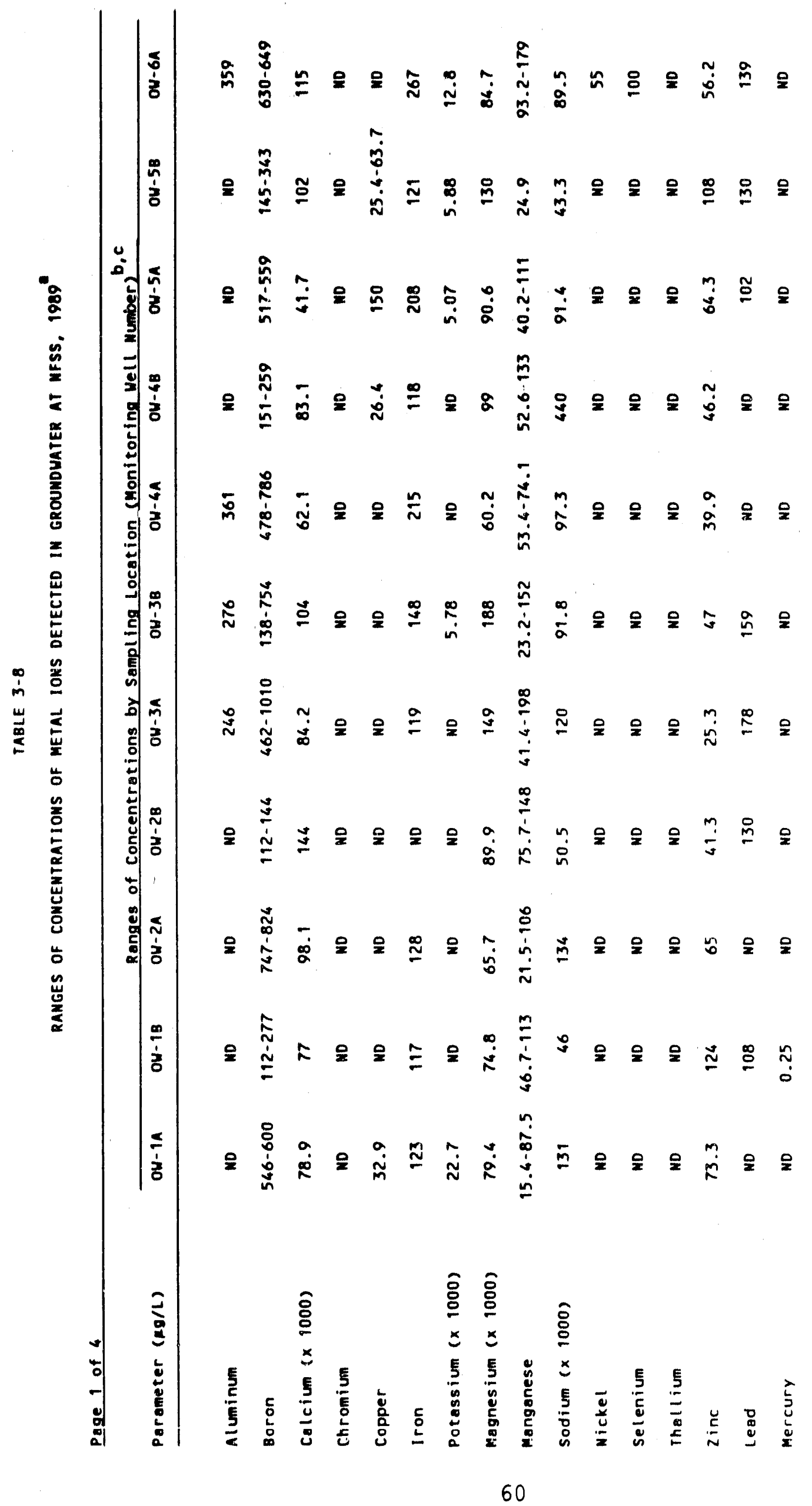




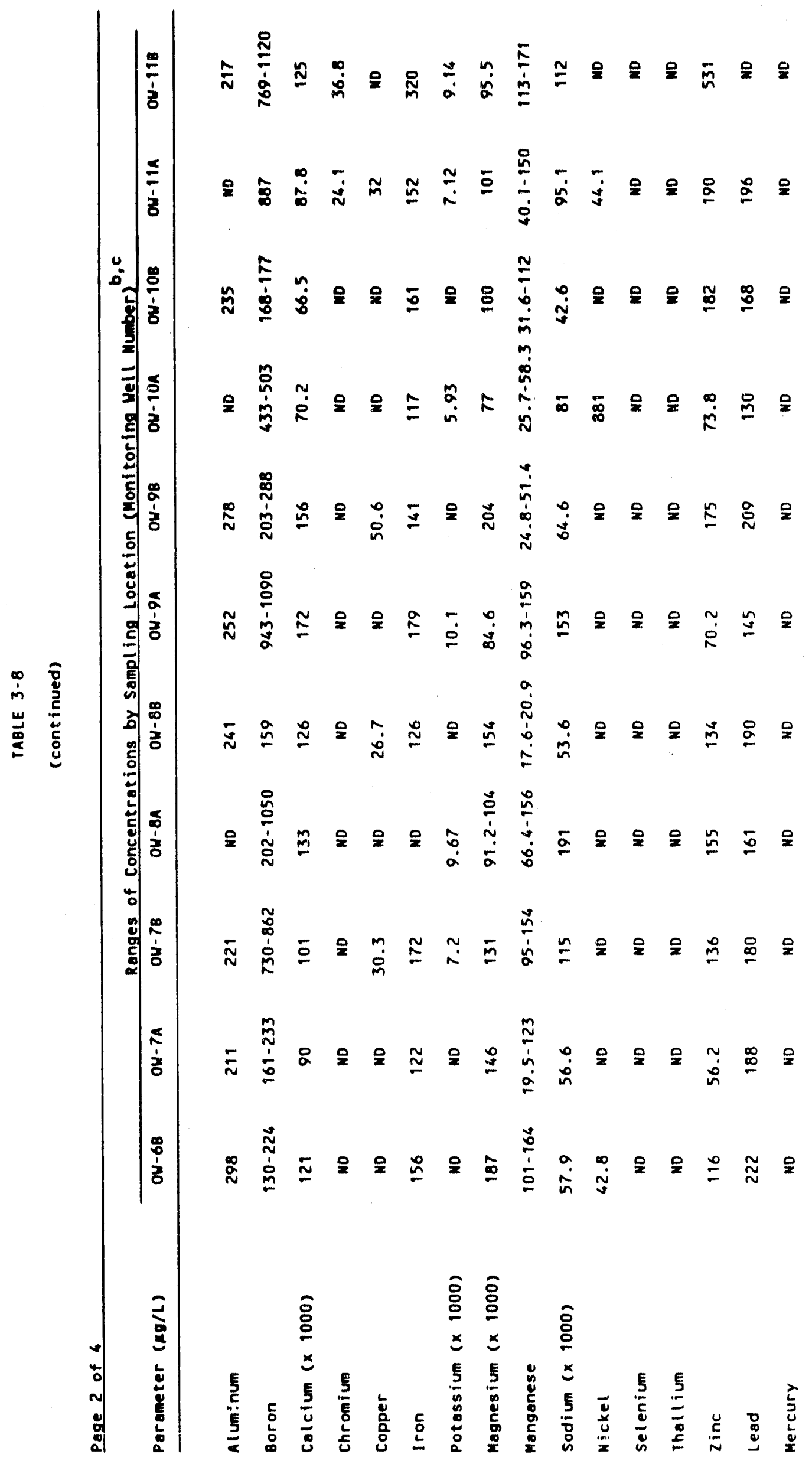

61 


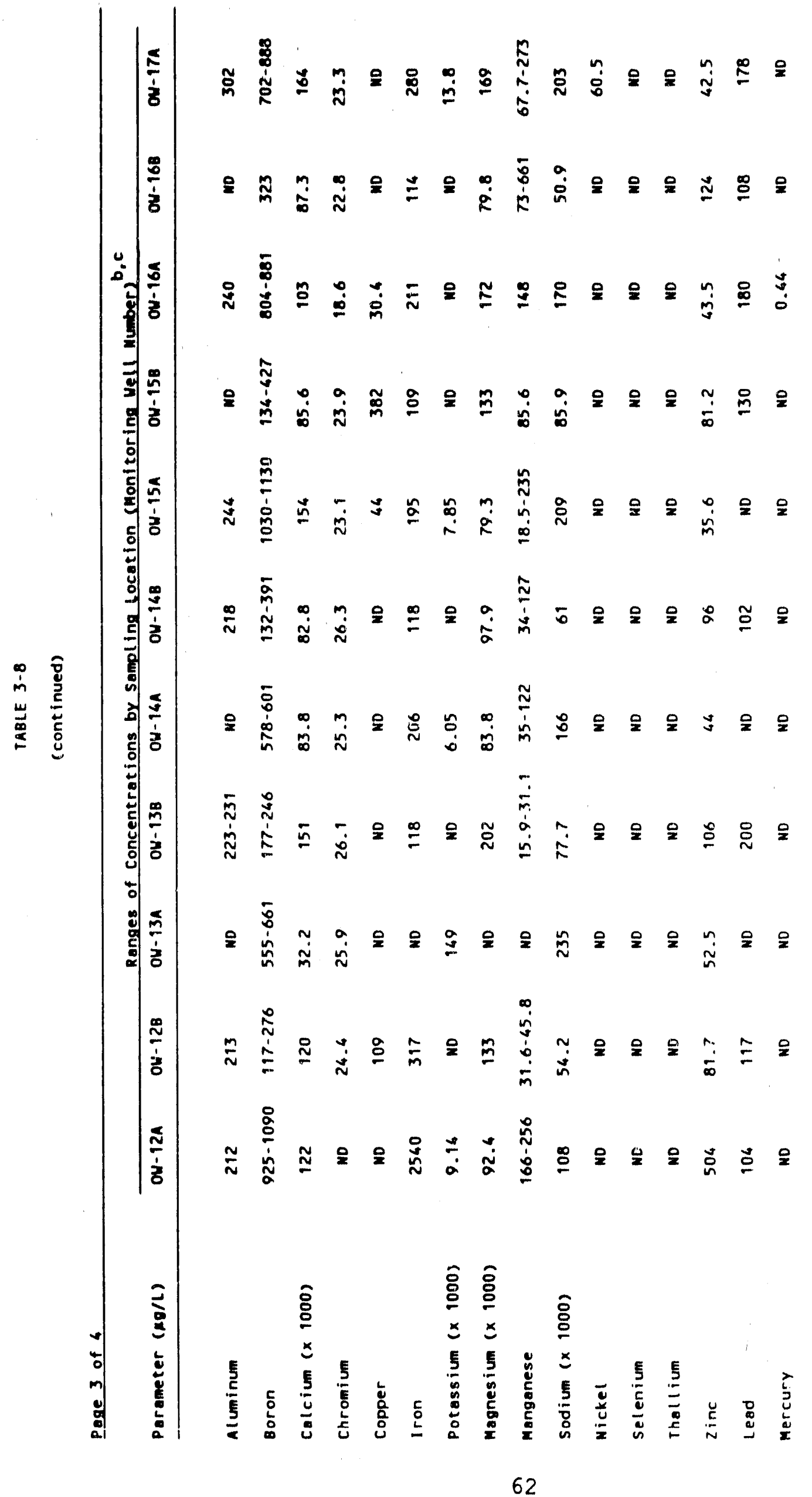




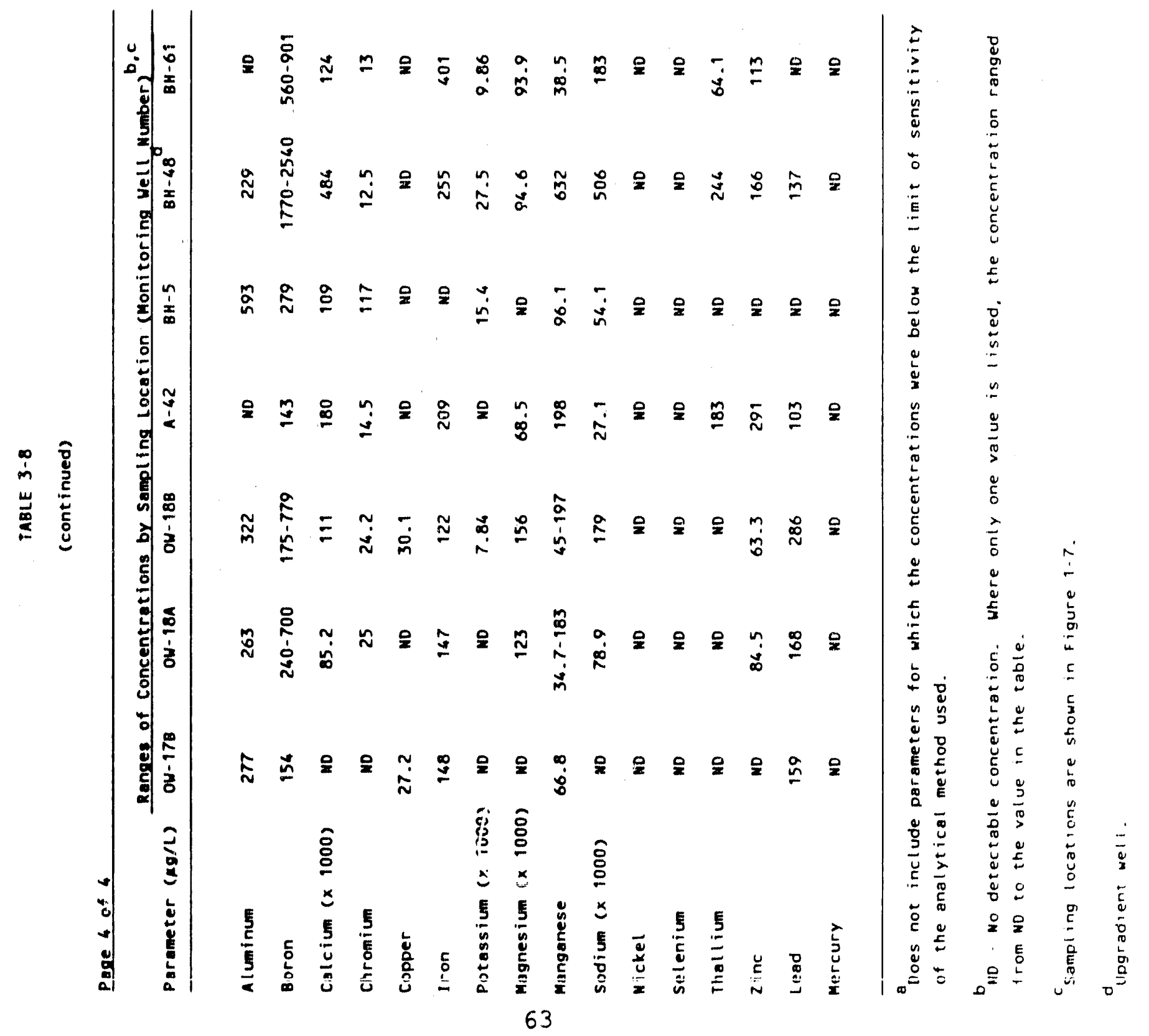


and $z$ inc were found in groundwater at concentrations that approximate those found in groundwater from the upgradient well BH-48. In general, elevated levels of calclum and magnesium, which are common in the area (as evidenced by their concentrations in the upgradient well), reduce the acceptablilty of groundwater for industrial or residential use. Arsenic, barium, beryllium, cobalt, molybdenum, antimony, and vanadium, which were found in 1988, were not detected in 1989. Lead was not found in 1988 but was detected in many wells, including an upgracident well, in 1989. Mercury was detected in two wells in 1989.

Comparison of the concentrations detected with maximum contaminant levels (MCLs) promulgated under the Safe Drinking Water Act indicates that water beneath NFSS would require treatment before it could be used as a public drinking water supply. The contaminants present do not exceed MCLs by more than a factor of 20, and some are present at concentrations at or below relevant MCLs, Comparison of downgradient well BH-61 with site wells and with upgradient well BH-48 indicates that NFSS is having no impact on groundwater quality outside the NFSS boundary.

\subsection{SEDIMIENT SAMIPLING}

During 1989, sediment samples consisting of composites weighing approximately $500 \mathrm{~g}$ ( $1.1 \mathrm{lb}$ ) were collected on site and off site at surface water sampling locations $9,10,11,12$, and 20 (see Figures $3-2$ and $3-3$ ). The rationale for placement of the sampling locations is as stated in subsection 3.3 .

TMA/E analyzed the samples for total uranium and radium-226. The uranium concentration was obtained by summing the results from isotopic uranium analyses. Isotopic uranium was determined by alpha spectrometry, where the uranium has been leached and organically extracted and electroplated on a metal substrate. Radium-226 concentrations were determined by radon emanation (described in subsection 3.3).

The analytical results (based on ary weight) for total uranium and radium are presented in Table 3-9. The average on-site and 
TABLE 3-9

TOTAL URANIUM AND RADIUM-226 CONCENTRATIONS

IN NFSS SEDIMENT SAMPLES, 1989

\begin{tabular}{|c|c|c|c|}
\hline \multirow{2}{*}{$\begin{array}{l}\text { Sampling } \\
\text { Locationa }\end{array}$} & \multirow{2}{*}{$\begin{array}{c}\text { Number of } \\
\text { Samples }\end{array}$} & \multicolumn{2}{|c|}{ Concentration $[p c 1 / g$ (dry)] } \\
\hline & & Minimum Maximum & Average \\
\hline
\end{tabular}

\section{Uranium}

on site

$\begin{array}{rrrrr}10 & 2^{b} & 3.2 & 14.5 & 8.8 \\ 11 & 3^{c} & 1.5 & 2.5 & 2.1\end{array}$

off stice

$\begin{array}{lllll}12 & 3^{\mathrm{C}} & 1.4 & 1.5 & 1.4 \\ 20 & 2^{\mathrm{b}} & 1.4 & 1.6 & 1.5\end{array}$

Background
9
$2^{c}, d$
$2 \cdot 4$
2.8
2.6

Radium-226

on site
10
$3_{3}^{\mathrm{c}}$
0.9
3.0
1.8
11
0.9
2.8
1.7

off site
12
20
$2^{3 \mathrm{c}}$
0.5
0.9
0.8
0.8
0.8
0.8

Background

9

$$
2^{c, d}
$$

1.0

1.0

1.0

a Sampling locations are shown in Figures 3-2 and 3-3.

bocation was frozen in the first quarter; no sample taken in the third quarter.

CLocation was frozen in the first quarter.

docation was established in october 1988 at the south 31 Ditch. 
off-site concentrations are approximately the same and probabily reflect background concentrations. All measured concentrations are within DOE derived concentration guidelines for solls. (Currently DOE does not have guidelines for radioactivity levels in sediments.)

\subsection{RADIATION DOSE}

To assess the environmental significance of possible release of radionuclides from radioactive materials stored at NFSS, radiological exposure pathways were evaluated to calculate the dose to a hypothetical maximally exposed individual. This hypothetical individual is one who is assumed to be adjacent to the site and who, when all potential routes of exposure are considered, receives the largest dose. An appraisal of potential pathways (exposure to external gamma radiation, ingestion of water, and inhalation of radon) suggested that exposure to external gamma radiation was the only plausibly significant exposure mode.

The potential dose from ingesting groundwater or surface water from sources on NFSS property was not calculated because it was considered unrealistic to assume that ingestion of this water would occur. NFSS is fenced and locked and securlty is well maintained, so a member of the public could consume significant volumes of water on the site only by trespassing on the property and consuming water daily. To consume groundwater from a well at NFSS, the member of the public would also have to be equipped with a means of extracting the groundwater, such as a baller or puinp. Given the levels of contamination found in surface water on the site, one would have to drink approximately $36,000 \mathrm{~L}(9,500 \mathrm{gal})$ to exceed the DOE radiation protection standard of $100 \mathrm{mrem} / \mathrm{yr}$.

Radon concentrations measured at the boundary of NFSS were within the normal variation associated with background measurements for this area. Consequently, this pathway would not contribute additional exposure to the maximally exposed individual. 


\subsubsection{Dose to the Maximally Exposed Individual}

To ldentify the individual in the vioinity of NFSS who would recelve the highest dose from on-site low-level radioactive materials, potential exposures from external gamma radiation were calculated at varlous monitoring locations that could be accessible to the public. These exposures were then reviewed with regard to land use and occupancy factors for areas adjacent to the monitoring points. From these calculations, it was determined that the highest exposure would be recelved by an individual directly east of the site.

The highest measured radiation level above background, $8 \mathrm{mrem} / \mathrm{Yr}$, was recorded at TLD station 20. As shown in Figure 1-5, the axea adfacent to this station is used as a sanitary landfill. Exposure to people in this area is therefore conservatively based on a 40-h work week, although it is highly unlikely that a worker would spend this much time near this sampling location. Applying a 40-h/week occupancy factor, the exposure to landfill workers would be a maximum of $2 \mathrm{mrem} / \mathrm{yr}$ above background. This exposure is approximately equivalent to 2 percent of the DOE radiation protection standard. This scenario is conservative in that it is highly unlikely that any individual would spend so much time at this location. By comparison, this exposure is less than a person would receive during a one-way flight from New York to Los Angeles from the greater amounts of cosmic radiation at higher altitudes ( $s \in e$ Appendix D).

\subsubsection{Dose to the Population in the Vicinity of NFSS}

The dose to the population represents the conceptual cumulative radiation dose to all residents within an $80-\mathrm{km}(50-\mathrm{mi})$ radius of a given site. This estimated dose includes contributions from al 1 potential pathways. For NFSS, these pathways are direct exposure to gamma radiation, inhalation of radon, and ingestion of water containing radioactivity. 
The contribution to the population dose made by gamma radiation from on-site radioactive materials is too small to be measured because gamma radiation levels decrease rapidly as distance from the source of contamination inoreases. For example, if the gamma exposure rate st a distance of $0.9 \mathrm{~m}(3 \mathrm{ft}$ ) from a small-area radioactive source were $100 \mathrm{mrem} / \mathrm{yr}$, the exposure rate at a distance of $6.4 \mathrm{~m}(21 \mathrm{ft})$ from the source would be indistinguishable from naturally occurring background radiation.

similarly, radon is known to dissipate rapldiy as distance from the radon source increases (Ref. 10). Therefore, radon exposure does not contribute significantly to population dose.

On the basis of radionuclide concentrations measured in water leaving the site, it also appears that there is no predictable pathway by which ingestion of water could result in a significant dose to the population. As water migrates farther from the source, radionuclide concentrations are further reduced, thereby lowering potential doses even further.

The oumulative dose to the population within an $80-\mathrm{km}$ (50-mi) radius of NFSS that results from radioactive materials present at the site is indistinguishable from the dose the same population recelves from naturally occurring radloactive sources.

\subsection{TRENDS}

The environmental monitoring program at NFSS was established to allow an annual assessment of the environmental conditions at the site, provide a historical record for year-to-year comparisons, and permit detection of trends. In the following subsections, 1989 annual averages for each monitoring location for radon, external gamma radiation, and radionuclide concentrations in surface water and groundwater are compared with results for 1985-1988 for the corresponding locations.

In some cases, sampling locations monitored in earlier years no longer exist (because of adjustments in the monitoring program or changes resulting from remedial action). Data from such locations 
would not be valld for comparlsons or trends and therefore are not reported in the trend tables. Comparisons and trends are based on current monitoring locations; when there are gaps or anomalies in the data reported for these locations in past years, these are footnoted and explained in the tables. As the environmental monitoring program continues at NFSS and more data are collected, comparisons and analyses of trends will become more meaningful.

\subsubsection{Radon}

As Table 3-10 shows, radon concentrations at the NFSS site boundary measured from 1985 through 1989 are all low, have not fluctuated notably, and approximate background levels for the area.

\subsubsection{External Gamma Radiation}

As shown in Table 3-11, although there has been some fluctuation, external gamma radiation levels in 1989 were lower than those measured from 1985 through 1988 and are essentially equal to or less than the measured background value.

\subsubsection{Surface Water}

As shown in Tables $3-12$ and $3-13$, no trends in total uranium and radium-226 concentrations in surface water are evident from 1985 to 1989. Levels have fluctuated only slightly and remain very low.

\subsubsection{Groundwater}

As shown in Tables $3-12$ and $3-13$, there have been no noticeable trends in the concentrations of uranium or radium-226 in groundwater at NFSS. Since the current monitoring wells were installed in 1983, most locations have reported concentrations that have remained basically stable. 


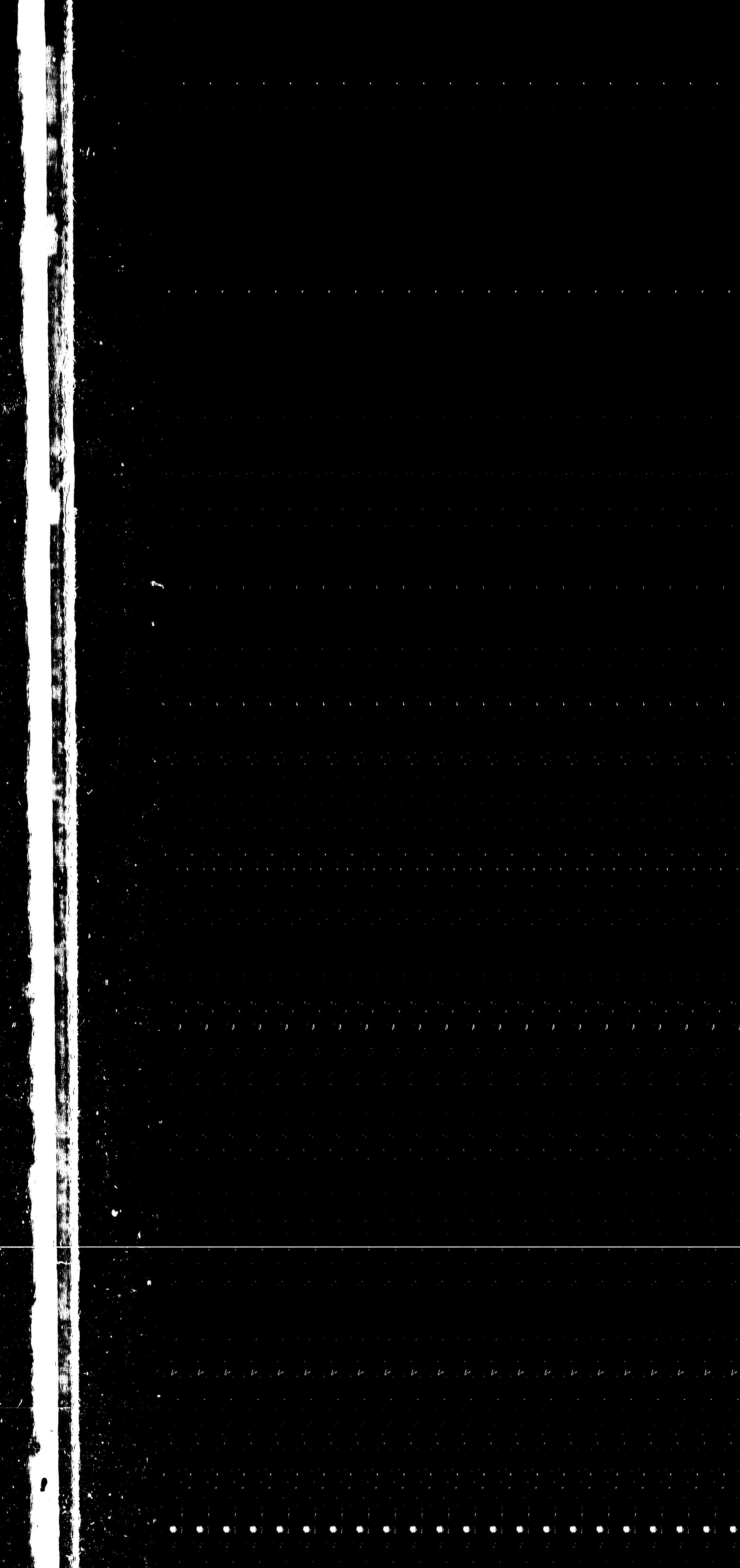


TABLE 3-10

ANNUAL AVERAGE CONCENTRATIONS OF RADON-222 MEASURED

AT NFSS BOUNDARY, 1985-1989

\begin{tabular}{|c|c|c|c|c|c|}
\hline \multirow{2}{*}{$\begin{array}{l}\text { Sampling } \\
\text { station }\end{array}$} & \multicolumn{5}{|c|}{ concentration $\left(10^{-9} \mu \mathrm{Ci} / \mathrm{ml}\right) \mathrm{c}, \mathrm{d}$} \\
\hline & 1985 & 1986 & 1987 & 1988 & 1989 \\
\hline
\end{tabular}

Site Bounda $x$

$\begin{array}{llllll}1 & 0.4 & 0.3 & 0.2 & 0.5 & 0.4 \\ 3 & 0.5 & 0.3 & 0.3 & 0.2 & 0.4 \\ 4 & 0.4 & 0.3 & 0.4 & 0.2 & 0.4 \\ 5 & 0.2 & 0.3 & 0.2 & 0.5 & 0.7 \\ 6 & 0.4 & 0.2 & 0.2 & 0.4 & 0.4 \\ 7 & 0.6 & 0.2 & 0.3 & 0.4 & 0.8 \\ 11 & 0.4 & 0.4 & 0.2 & 0.2 & 0.4 \\ 12 & 0.4 & 0.2 & 0.3 & 0.3 & 0.5 \\ 13 & 0.5 & 0.4 & 0.1 & 0.5 & 0.7 \\ 14 & 0.3 & 0.8 & 0.4 & 0.3 & 0.5 \\ 15 & 0.3 & 0.3 & 0.2 & 0.3 & 0.4 \\ 20 & 0.5 & 0.2 & 0.2 & 0.5 & 0.4 \\ 28 & 0.4 & 0.3 & 0.2 & 0.3 & 0.5 \\ 29 & 0.6 & 0.4 & 0.3 & 0.3 & 0.8 \\ 32 & 0.4 & 0.3 & 0.3 & 0.3 & 0.6 \\ 34 & 0.5 & 0.3 & 0.8 & 0.2 & 0.5 \\ 35 & 0.3 & 0.2 & 0.2 & 0.5 & 0.4 \\ 36 & 0.4 & 0.3 & 0.2 & 0.3 & 0.4\end{array}$

Background

$30 \mathrm{e}$
$120 \mathrm{f}$
1219

$\begin{array}{rrrrr}0.4 & 0.3 & 0.3 & 0.6 & 1.4 \\ -- & -- & -- & 0.5 & 0.5 \\ -- & -- & -- & 0.5 & 0.4\end{array}$

a Data sources for 1985-1988 are the annual site environmental reports for those years (Refs. 10-13).

bocations of sampling stations are shown in Figure $3-1$.

$c_{1} \times 10^{-9} \mu \mathrm{Ci} / \mathrm{ml}$ is equivalent to $1 \mathrm{pCi} / \mathrm{L}$.

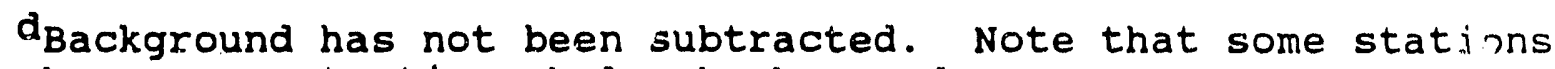
have concentrations below background.

eLocated at Seneca St., Lewiston, NY, approximately $6.4 \mathrm{~km}$ (4 mi) southwest of NFSS.

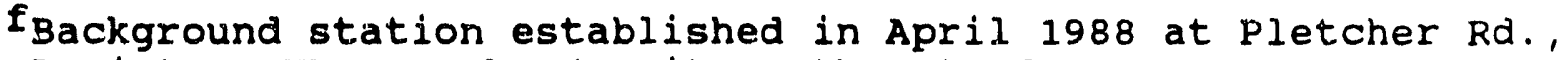
Lewiston, NY, $1.6 \mathrm{~km}$ ( 1 i) southwest of NFSS.

9Background station established in April 1988 at the intersection of Route 104 and Swain Rd., Lewiston, NY, $1.6 \mathrm{~km}$ (1 mi) south of NFSS. 
TABLT 3-11

ANNUAL AVERAGE EXTERNAJ, GAMMA RADIATION LEVEIS

AT NFSS, 1985-1989a

Page 1 of 2

Sampling

Radiation Level (mrem/yr) C

station

$\begin{array}{ccc}\text { Radiation Level } & \text { (mrem/yr) C } \\ 1985 & 1986 & 1988\end{array}$

1989

\section{Site Boundary}

\begin{tabular}{|c|c|c|c|c|c|}
\hline 1 & 18 & 16 & 11 & 11 & od \\
\hline 3 & 24 & 4 & 11 & 9 & $0^{d}$ \\
\hline 4 & 48 & 14 & 13 & 7 & $0^{d}$ \\
\hline 5 & 24 & 14 & 16 & 22 & 2 \\
\hline 6 & 21 & 8 & 3 & 16 & $0^{d}$ \\
\hline 7 & 20 & 8 & 11 & 7 & 2 \\
\hline 11 & 12 & 4 & 2 & 5 & $0^{d}$ \\
\hline 12 & 11 & 2 & 6 & 8 & $0^{d}$ \\
\hline 13 & 14 & $0^{d}$ & $0^{d}$ & 6 & 1 \\
\hline 14 & 6 & 3 & 7 & 14 & $0^{d}$ \\
\hline 15 & 3 & 6 & 6 & 24 & 3 \\
\hline 20 & 65 & 26 & 24 & 23 & 8 \\
\hline 28 & 14 & 14 & 14 & 10 & 2 \\
\hline 29 & 14 & $0^{d}$ & $0^{d}$ & 10 & $0^{d}$ \\
\hline $32^{e}$ & 10 & 6 & 5 & 8 & $0^{d}$ \\
\hline 34 & 16 & 6 & 8 & 3 & $0^{d}$ \\
\hline 35 & 16 & 15 & 14 & 14 & \\
\hline 36 & 6 & 5 & 16 & 10 & d \\
\hline
\end{tabular}

Background

$30 \mathrm{f}$
$120 \mathrm{~g}$
$121 \mathrm{~h}$

91

69

$64 \quad 71$

61

--

-- $\quad--$

83

$121^{\mathrm{h}}$

$--$

$--$

$-$

a Data sources for 1985-1988 are the annual site environmental reports for those years Refs. 10-13).

bsite boundary stations only. Locations of sampling stations are shown in Figure 3-1.

CMeasured background has been subtracted from readings taken at site boundary stations.

dMeasurement was equal to or less than neasured background value. estation 32 is a quality control for station 12. 
TABLE 3-11

(continued)

\section{Page 2 of 2}

fstation 30 was established in 1985, approximately $6.4 \mathrm{~km}$ (4 $\mathrm{mi})$ southwest of NFSS at Seneca St., Lewiston, NY.

Istation 120 was established in April 1988 at Pletcher Rd., Lewiston, NY, approximately $1.6 \mathrm{~km}(1 \mathrm{mi})$ southwest of NFSS.

$h_{\text {Station }} 121$ was established in April 1989 at the intersection of Route 104 and Swain Rd., Lewiston, NY, approximately $1.6 \mathrm{~km}$ (1 $\mathrm{mi})$ south of NFSS. 
TABLE 3-12

ANNUAL AVERAGE CONCENTRATIONS OF TOTAL URANIUM

IN NFSS WATER SAMPLES, 1985-1989a

\begin{tabular}{|c|c|c|c|c|c|}
\hline \multirow{2}{*}{$\begin{array}{l}\text { Sampling } \\
\text { Locationb }\end{array}$} & \multicolumn{5}{|c|}{ Concentration $\left(10^{-9} \mu \mathrm{Ci} / \mathrm{ml}\right) \mathrm{C}$} \\
\hline & 1985 & 1986 & 1987 & 1988 & 1989 \\
\hline
\end{tabular}

Surface Water

on site

10

11

Off site

12

20

$\frac{\text { Background }}{9^{d}}$

Groundwater

\begin{tabular}{c} 
on site \\
\hline$B H-5$ \\
$B H-48$ e \\
$B H-61$ f \\
$A-42$ \\
$A-50$ \\
$A-52$
\end{tabular}

15

19

9

4

4

5

8
5

6
14

7

10

21

16

10

5
6

6

7

4

8

9

aData sources for 1985-1988 are the annual site environmental reports for those years (Refs. 10-13).

bsampling locations are shown in Figures 3-2 and 3-3 (surface water) and 1-7 (groundwater). Sampling locations that

have existed in previous years but that no longer exist because of adjustments in the monitoring program or changes caused by remedial action are not reported in trend tables. Data from these locations would not be valid for comparisons or trends.

$c_{1} \times 10^{-9} \mu \mathrm{Ci} / \mathrm{ml}$ is equivalent to $1 \mathrm{pCi} / \mathrm{L}$.

docation established in october 1988 at the south 31 Ditch.

eupgradient well.

f Downgraadieñt well. 
TABLE $3-13$

ANNUAL AVERAGE CONCENTRATIONS OF RADIUM-226

IN NFSS WATER SAMPLES, 1985-1989a

\begin{tabular}{|c|c|c|}
\hline Sampling & Concen & $n$ \\
\hline Locationb & 1985 & 1987 \\
\hline
\end{tabular}

Surface water

On site

$\begin{array}{llllll}10 & 0.4 & 0.2 & 0.2 & 0.2 & 0.6 \\ 11 & 0.7 & 0.3 & 1.8 & 1.0 & 2.5\end{array}$

Off site

12

20

0.2

0.3

0.3

0.3

1.0

0.6

0.4

0.4

0.3

0.5

$\frac{\text { Background }}{9^{d}}$

Groundwater

\begin{tabular}{l} 
On site \\
\hline$B H-5$ \\
$B H-48$ e \\
$B H-61$ f \\
$A-42$ \\
$A-50$ \\
$A-52$
\end{tabular}

$\begin{array}{ll}0.5 & 0.5 \\ 0.6 & 0.5 \\ 0.5 & 0.3 \\ 0.5 & 0.6 \\ 0.7 & 0.5 \\ 0.2 & 0.3\end{array}$

0.4

0.3

0.4

$\mathrm{BH}-48 \mathrm{e}$

0.5

0.5

0.7

$\mathrm{A}-42$

0.6

0.3

0.7

0.4

A-52

0.2

0.2

0.3

0.6

0.3

0.5

0.5

0.2

0.3

0.6
aData sources for 1985-1988 are the annual site environmental reports for those years (Refs. 10-13).
bampling locations are shown in Figures 3-2 and 3-3 (surface water) and 1-7 (groundwater). Sampling locations that have existed in previous years but that no longer exist due to adjustments in the monitoring program or changes caused by remedial action are not reported in trend tables. Data from these locations would not be valid for comparisons or trends.

$C_{1} \times 10^{-9} \mu \mathrm{Ci} / \mathrm{ml}$ is equivalent to $1 \mathrm{pCi} / \mathrm{L}$.

docation established in october 1988 at the south 31 Ditch.

eupgradient well.

f Downgradient well. 
The uranium concentration in well A-42 has been consistently above that measured in the other wells. This well was installed during the early days of remedial action on the site; a review of historical records lrokigates that it was drilled in an area that had been radioactively yontaminated. An investigation was completed in 1988 in an effort to determine why data for A-42 are atypical. A summary of this effort is presented in

Subsection 3.4 .

Tables 3-14 and 3-15 give total uranium and radium-226

concentrations in containment monitoring welis in 1987, 1988, and 1989. No trends are evident at this time. As more data are accumulated, trends will be further evaluated. 
TABLE 3-14

ANNUAL AVERAGE CONCENTRATIONS OF TOTAL URANIUM IN NFSS CONTAINMENT MONITORING WELLS, 1987-1989

\begin{tabular}{|c|c|c|c|}
\hline \multirow{2}{*}{$\begin{array}{l}\text { Sampling } \\
\text { Locationa }\end{array}$} & \multicolumn{3}{|c|}{ concentration $\left(10^{-9}\right.$} \\
\hline & 1987 & 1988 & 1989 \\
\hline$O W-1 A$ & 4 & $<3$ & 4 \\
\hline$O W-1 B$ & 4 & 5 & 8 \\
\hline$O W-2 A$ & 3 & $<3$ & 4 \\
\hline$O W-2 B$ & 5 & 8 & 9 \\
\hline$O W-3 A$ & 3 & 4 & 8 \\
\hline$O W-3 B$ & 10 & 14 & 17 \\
\hline$O W-4 A$ & 3 & $<3$ & 3 \\
\hline$O W-4 B$ & 6 & 7 & 7 \\
\hline$O W-5 A$ & 3 & 4 & 4 \\
\hline$O W-5 B$ & 1.1 & 10 & 12 \\
\hline$O W-6 A$ & 3 & $<3$ & 3 \\
\hline$O W-6 B$ & 15 & 14 & 13 \\
\hline$O W-7 A$ & 8 & 10 & 10 \\
\hline$O W-7 B$ & 3 & 5 & 3 \\
\hline $0 W-8 A$ & 3 & 3 & 5 \\
\hline$O W-8 B$ & 17 & 20 & 20 \\
\hline$O W-9 A$ & 3 & 4 & 5 \\
\hline OW-9B & 14 & 20 & 20 \\
\hline$O W-10 A$ & 5 & 4 & $<3$ \\
\hline$O W-10 B$ & 3 & 6 & 7 \\
\hline$O W-11 A$ & 36 & 28 & 32 \\
\hline$O W-11 B$ & 3 & 4 & $<3$ \\
\hline$O W-12 A$ & 3 & 5 & 7 \\
\hline$O W-12 B$ & 15 & .14 & 10 \\
\hline$O W-13 A$ & 3 & 4 & $<3$ \\
\hline$O W-13 B$ & 14 & $\perp 7$ & 17 \\
\hline$O W-14 \mathrm{~A}$ & 4 & 4 & $<3$ \\
\hline$O W-14 \mathrm{~B}$ & 5 & 7 & 6 \\
\hline$O W-15 A$ & 3 & 4 & $<3$ \\
\hline$O W-15 B$ & 6 & 7 & 14 \\
\hline$O W-16 \mathrm{~A}$ & 3 & 5 & 3 \\
\hline$O W-16 B$ & 6 & 7 & 11 \\
\hline$O W-17 A$ & 3 & 4 & 4 \\
\hline$O W-17 B$ & 7 & 8 & 8 \\
\hline$O W-19 A$ & 3 & 4 & 5 \\
\hline$O W-18 B$ & 14 & 18 & 19 \\
\hline
\end{tabular}

asampling locations are shown in Figure 1-7.

$b_{1} \times 10^{-9} \mu \mathrm{Ci} / \mathrm{ml}$ is equivalent to $1 \mathrm{pCi} / \mathrm{L}$. 
TABLE $3-15$

ANNUAL AVERAGE CONCENTRATIONS OF RADIUM-226

IN NFSS CONTAINMENT MONITORING WELLS, 1987-1989

Sampling
Location $\quad \frac{\text { Concentration }\left(10^{-9} \mu \mathrm{Ml} / \mathrm{ml}\right)^{b}}{1987}$

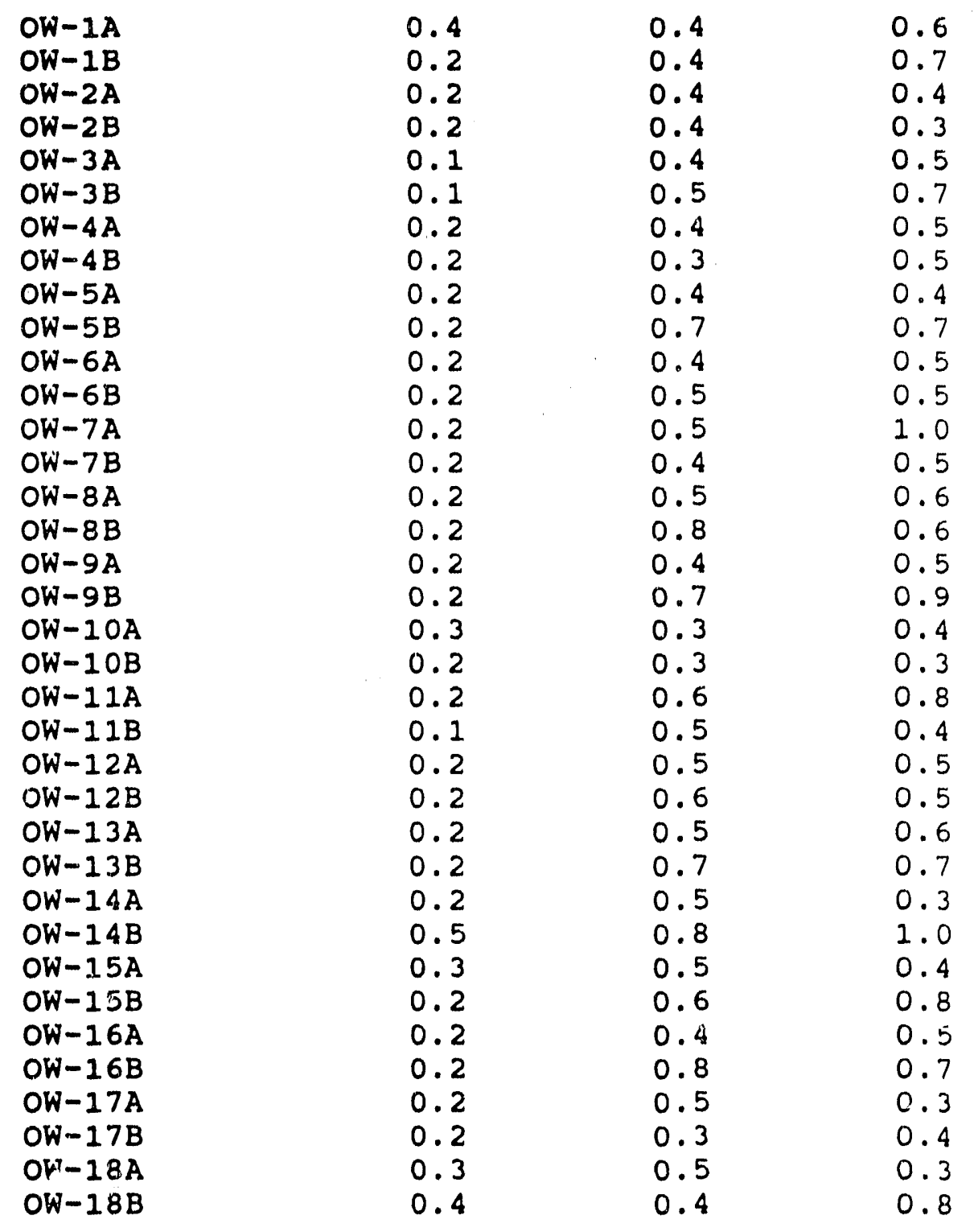

asampling locations are shown in Figure 1-7.

$b_{1} \times 10^{-9} \mu \mathrm{Ci} / \mathrm{ml}$ is equivalent to $1 \mathrm{pCi} / \mathrm{L}$. 


\subsection{RGLATED ACTIVITIES AND SPECIAL, STUDIES}

\subsection{RETATED ACTIVITIES}

site maintenance, security, and monitoring continued.

\subsection{SPECINU STUDIES}

No special studies were performed in 1989 . 


\section{REFERENCES}

1. Bechtel National, Ino. Design Report for the Waste containment Facility at the Niagara Falls storage site, DOE/OR/20722-21, Oak Ridge, Tenn., May 1986.

2. Bechtel National, Ino. Geologic Report for the Niagara Fal is Storage Site, DOE/OR/20722-8, Oak Ridge, Tenn., June 1984.

3. U. S. Department of Energy. Einal Environmental Impact Statement: Long-Term Management of the Existing Radioactive Wastes and Residues at the Niagara Falls storage Site, DOE/EIS-0109F, Washington, D.C., April 1986.

4. Gale Research Company. Climate of the states, 3rd Edition, Vol. 1, Detroit, Mich., 1985.

5. Battelle Columbus Laboratories. A Comprehensive Characterization and Hazard Assessment of the DOE Niagara Falis storage site, BNI-074, Columbus, Ohio, June 1981.

6. Bechtel National, Inc. Letter, R.C. Robertson (BNI) to J.F. Wing (DOE-TSD), "Proposed Revisions to the Environmental Monitoring Program at the New York Sites," CCN 057996, Oak Ridge, Tent, Dec. 22, 1988.

7. Bechtel National, Inc. Niagara Fa is storage site Environmental Monitoring Report - C alendar Year 1982, Report No. 10-05-202-002, Oak Ridge, Tenn., May 1983.

8. Bechtel National, Inc. Niagara Falls storage Site Environmental Monitoring Report - Calendar Year 1983, DOE/OR/20722-18, Oak RIdge, Tenn., July 2984. 
9. Bechtel National, Ino. Niagara Falle Storage Site Environmental Monitoring Report - Colendar Year 1984, DOE/OR/20722-55, Oak Ridge, Tenn., July 1985.

10. Bechtel National, Inc. Niagara Falis Storage Site Annual stte Environmental Report - Calendar Year 1985, DOE/OR/20722-98, Oak Ridge, Tenn., April 1986.

11. Bechtel National, Ino. Niagara Falls Storago Site Annual Site Environmenta1 Report - Calendar Year 1986, DOE/OR/20722-150, Oak Ridge, Tenn., June 1987.

12. Bechtel National, Inc. Niagara Falls Storage Site Annual Environmental Report - Calendar Year 1987, DOE/OR/20722-197, Oak Ridge, Tenn., April 1988.

13. Bechtel National, Inc. Niagara Falls Storage Site Annual Site Environmental Report - Calendar Year 1988, DOE/OR/20\%22-219, Oak Ridne, Tenn., April 1989.

14. Acres American, Incorporated. Hydrologic and Geologic Characterization of the DOE-Niagara Falls storage Site, prepared for NLO, Incorporated, Buffalo, N.Y., 1981.

15. Bechtel National, Inc. Geotechnical Post-Construction Report, Niagara Falis Storage Site, Lewiston, New York, Vol. 5: Interim Cap construction, Waste containment Area Monitoring System and Permeability Testing, May-November 1986 , DOE/OR/10-20-202-005, Oak Ridge, Tenn., Novembar 1986.

16. Bechtel National, Inc. Instruction Guide for well $A-42$ Investigation, Niagara Falls Storage Site, Lewiston. New York, No. 202-IG-0U7, Desember 1988. Issued as an attachment to a letter from R.C. Robertson (BNI) to W.M. Seay (DOE-TSD), Oak Ridge, Tenn., December 22, 1988. 
17. U.S. Department of Energy. Order 5400.5, Badiation Protection of the public and the Invironment, February 8 , 1090 .

18. Eisenbud, M. Environmental Radioactivity. New York: Viking Press, 1987. 
APPENDIX A

QUALITY ASSURANCE 


\section{QUALITY ASSURANCE}

A cumprehensive quality assurance (QA) program involving sampling, data manngement, and analysis was maintained to ensure that the data reported were representative of actual concentrations in the environment. The QA program meets the requirements of DOE order $5700.6 \mathrm{~B}$ and ANSI/ASME NQA-1.

QA sampling requirements were ensured through the following:

- Samples at all locations collected using established procedures

- Sampling program design provided for spikes, trip blanks, fleld blanks, and quality control (QC) duplicate sampling

- Chain-of-custody procedures implemented to maintain traceabljity of samples and corresponding analytical results

Data management $Q A$ was achieved through:

- Completion and recording of parameter-specific data review checklists for each analysis report

- Use of alculation sheets for constructing data tables and documenting computations

- Double-checking and concurrence on calculations

- By the originator

- By an independent, equally qualified second party

System QA audits are conducted by BNI FUSRAP project QA personnel to verify adherence with lahoratoxy procedures and to evaluate the appropriateness and effectiveness of the procedures. Audit taam leaders and auditors are trained and certified in accordance with project procedures. Technical speclalists particlpate as auditors under the ulrection of the audit team leader when warranted by the nature of the activities being audited. Audit reports are prepared for each audit conducted. Audit firidings that require corrective action and followup are 
documented, tracked, and resolved, as verified by the project $Q A$ supervisor.

Routine radioanalyses for the FUSRAP Environmental Monitoring Program were performed under subcontract by TMA/E, Albuquerque, New Mexico. This laboratory maintained an internal quality assurance program that involved routine calibration of counting instruments, source and background counts, routine yield determinations of radiochemical procedures, and replicate analyses to check precision. The accuracy of radionuclide determination was determined through the use of standards traceable to the National Institute of standards and Technology (NIST), when available. When NIST standards were not available, standards from the New Brunswick Laboratory were used. The laboratory also participated in the Environmental Protection Agency's (EPA) Laboratory Intercomparison Studies program. In this program, samples of different environmental media (water, milk, air filters, soil, foodstuffs, and tissue ash) containing one or more radionuclides in known amounts were prepared and distributed to the participating laboratories. After the samples were analyzed, the results were forwarded to EPA for comparison with known values and with the results from other laboratories. This program enabled the laboratory to regularly evaluate the accuracy of its analyses and take corrective action if needed. Table A-1 summarizes results of the EPA comparison studies for water samples. TMA/E has applied and been accepted for readmission into the DOE Laboratory Quality Assessment Program for Radioactive Materials, coordinated by the DOE Environmental Laboratory, New York, New York.

Interlaboratory comparison of the tissue-equivalent TLD results was provided by participation in the International Environmental Dosimeter Project sponsored jointly by DOE, NRC, and EPA.

Chemical analyses were performed under subcontract by Weston Analytical Laboratory, Lionsville, Pennsylvania. Westoris standard practices manual was reviewed and accepted by BNI. The laburatory maintains an internal QA program that involves the following.

For inorganic analyses, the program includes: 
TABLE $A-1$

SUMMARY COMPARISON OF WATER SAMPLE RESULTS

(EPA and TMA/E)

\begin{tabular}{lcc}
\hline $\begin{array}{l}\text { Analysis and } \\
\text { Sample Date }\end{array}$ & Value $(\mathrm{PC} / \mathrm{L})$ & $\begin{array}{c}\text { Ratio } \\
\text { EPA }\end{array}$ \\
\hline
\end{tabular}

Alpha

$1 / 89$

$4 / 89$

$6 / 89$

$7 / 89$

$11 / 89$

Beta

$1 / 89$

$4 / 89$

$6 / 89$

$7 / 89$

$11 / 89$

$\underline{R a-226}$

$1 / 89$

$3 / 89$

$5 / 89$

$7 / 89$

$10 / 89$

\section{$\underline{R a-228}$}
$1 / 89$
$3 / 89$
$5 / 89$
$7 / 89$
$10 / 89$

\section{U (Natural)}
$1 / 89$
$5 / 89$
$7 / 89$
$9 / 89$

$$
\begin{array}{r}
54.0 \pm 5.0 \\
4.0 \pm 5.0 \\
50.0 \pm 5.0 \\
57.0 \pm 5.0 \\
6.0 \pm 5.0
\end{array}
$$

$$
\begin{array}{r}
41.0 \pm 10.0 \\
8.0 \pm 5.0 \\
30.0 \pm 8.0 \\
29.0 \pm 7.0 \\
4.0 \pm 5.0
\end{array}
$$

$$
\begin{array}{r}
49.0 \pm 1.0 \\
13.0 \pm 1.0 \\
33.0 \pm 2.7 \\
30.3 \pm 2.1 \\
4.3 \pm 0.6
\end{array}
$$

1.20

1.63

1.10

1.04

1.08
0.98

1.33

1.17

0.89

1.12
$58.3 \pm 1.5$

$51.0 \pm 3.0$

$6.7 \pm 0.6$

$53.0+1.7$

1.10

1.05

0.82

1.11

0.97

$5.0 \pm 0.8$
$3.50 \pm 0.50$
$4.90 \pm 0.7$
$3.50 \pm 0.50$
$17.7 \pm 2.7$

$5.5 \pm 0.3$

$3.67 \pm 0.06$

$4.03 \pm 0.25$

$3.87 \pm 0.15$

$17.2 \pm 0.5$

$$
\begin{aligned}
& 5.2 \pm 0.8 \\
& 10.3 \pm 1.5 \\
& 1.70 \pm 0.30 \\
& 3.60 \pm 0.50 \\
& 18.3 \pm 2.7
\end{aligned}
$$
$6.1 \pm 0.2$
$11.3 \pm 0.7$
$1.77 \pm 0.30$
$5.20 \pm 3.04$
$24.8 \pm 0.3$

1.17

1. 10

1.04

1.44

1. 36

arhis ratio can be used to determine the accuracy of TMA/E's analytical procedures. 
- Initial calibration and calibration verification

- Continuing calibration verification

- Reagent blank analyses

- Matrix spike analyses

- Duplicate sample analyses

- Laboratory control sample analyses

- Interlaboratory QA/QC

For organic analyses, the program includes:

- Gas chromatography/mass spectrometry instrumentation for both volatile and semivolatile compound analysis

- Initial multilevel calibration for each Hazardous substances List (HSI) compound

- Matrix spike analyses

- Reagent blank analyses

- Interlaboratory QA/QC

- Continuing calibration for each HSL compound

- Addition of surrogate compounds to each sample and blanks for determining percent recovery information

Weston is currently an EPA-designated Contract Laboratory Program (CLP) laboratory for both organic and inorganic analyses. This requires passing EPA's blind performance evaluation testing each quarter. The technical specifications in BNI's subcontract with Weston specify QA/QC at, and in some cases beyond, the CLP level.

Currently, Weston participates in drinking water, wastewater, and/or hazardous waste certification programs. They are certified (or Finding) in 35 such state programs (including New York). Continued certification hinges upon Weston's ability to pass regular performance evaluation testing.

Weston's QA program also includes an independent overview by their project $Q A$ coordinator and a corporate vice president who aucits their program act vities quarterly. 
APPENDIX B

ENVIRONIENTAL STANDARDS AND CONVERSION FACTORS 


\section{ENVIRONIENTAL, STANDARDS}

The DOE long-term radiation protection standard of $100 \mathrm{mrem} / \mathrm{yr}$ includes exposure from all pathways except medical treatments (Ref. 17). Evaluation of exposure pathways and resulting dose calculations are based on assumptions such as occupancy factors in determining the dose from external gamma radiation; subtraction of background concentrations of radionuclides in air, water, and soil before calculating dose; closer review of water use, using the data that most closely represent actual exposure conditions rather than maximum values as applicable; and using average consumption rates of food and water per individual rather than maximums. Use of such assumptions will result in calculated doses that more accurately reflect the exposure potential from site activities. 
TABLE B-1

CONVERSION FACTORS

\begin{tabular}{|c|c|c|}
\hline 1 year & $=$ & 8,760 hours \\
\hline 12 & $=$ & $1,000 \mathrm{ml}$ \\
\hline $1 \mu \mathrm{Ci}$ & $=$ & $1,000,000 \mathrm{pCi}$ \\
\hline $1 \mathrm{pCi}$ & $=1$ & $0.000001 \mu \mathrm{Ci}$ \\
\hline $1 \mathrm{pCi} / \mathrm{L}$ & $=$ & $10^{-9} \mu \mathrm{Ci} / \mathrm{ml}$ \\
\hline $1 \mathrm{pCi} / \mathrm{L}$ & $=$ & $0.000000001 \mu \mathrm{Ci} / \mathrm{ml}$ \\
\hline $1 \mu \mathrm{Ci} / \mathrm{ml}$ & $=$ & $1,000,000,000 \mathrm{pCi} / \mathrm{L}$ \\
\hline $10^{-6}$ & $=$ & 0.000001 \\
\hline $10^{-7}$ & $=$ & 0.0000001 \\
\hline $10^{-8}$ & $=$ & 0.00000001 \\
\hline $10^{-9}$ & $=$ & 0.000000001 \\
\hline $10^{-10}$ & $=$ & 0.0000000001 \\
\hline $7 \times 10^{-10}$ & $=$ & 0.0000000007 \\
\hline $1 \mathrm{gal}$ & $=$ & $3.785 \mathrm{~L}$ \\
\hline $1 y^{3}$ & $=$ & $0.765 \mathrm{~m}^{3}$ \\
\hline $1 \mathrm{ft}$ & $=$ & $0.3048 \mathrm{~m}$ \\
\hline
\end{tabular}


APPENDIX C

ABBREVIATIONS AND ACRONYMS 


\section{ABBREVIATIONS}

cm

$\mathrm{cm} / \mathrm{s}$

ft

ft msl

g

gal

h

ha

in.

$\mathrm{km}$

$\mathrm{km} / \mathrm{h}$

Ib

m

$\mathrm{m}^{3}$

mg

$\mathrm{mg} / \mathrm{L}$

mi

m].

$\mathrm{mph}$

mrem

mrem/yr

$\mu \mathrm{Ci} / \mathrm{ml}$

$\mu \mathrm{R} / \mathrm{h}$

pCi

pci/g

pCi/L

$\mathrm{yd}^{3}$

yr centimeter

centimeters per second

foot

feet above mean sea level

gram

galion

hour

hectare

inch

kilometer

kilometers per hour

pound

meter

cubic meter

milligram

milligrams per liter

mile

milliliter

miles per hour

millirem

millirem per year

microcuries per milliliter

microroentgens per hour

picocurie

picocuries per gram

picocuries per liter

cubic yard

vear 


\section{ACRONYMS}

AEC

BNI

CLP

DOE

EPA

EPDM

HSL

IWCF

LOOW

NFSS

NIST

NYSDEC

$Q A$

QC

TLD

TMA/E
Atomic Energy Commisision

Bechtel National, Inc.

Contract Laboratory Program

Department of Energy

Environmental Protection Agency

ethylene propylene diene monomer

Hazardous Substances List

interim waste containment facility

Lake Ontario Ordnance Works

Niagara Falls Storage site

National Institute of standards and Technology

New York State Department of Environmental Conservation

quality assurance

quality contrul

thermoluminescent dosimeter

Thermo Analytical/Eberline 
APPENDIX D

RADIATION IN THE ENVIRONMENT 
Radlation is a natural part of our environment. When our planet was formed, radlation was present-and radiation surrounds it still. Natural radation showers down from the distant reaches of the cosmos and continuously radiates from the rocks, soll, and water on the Earth itself.

During the last century, mankind has dlscovered radiation, how to use $\mathrm{H}$, and how to control it. As a result, some manmade radiotion has been added to the natural amounts present in our environment.

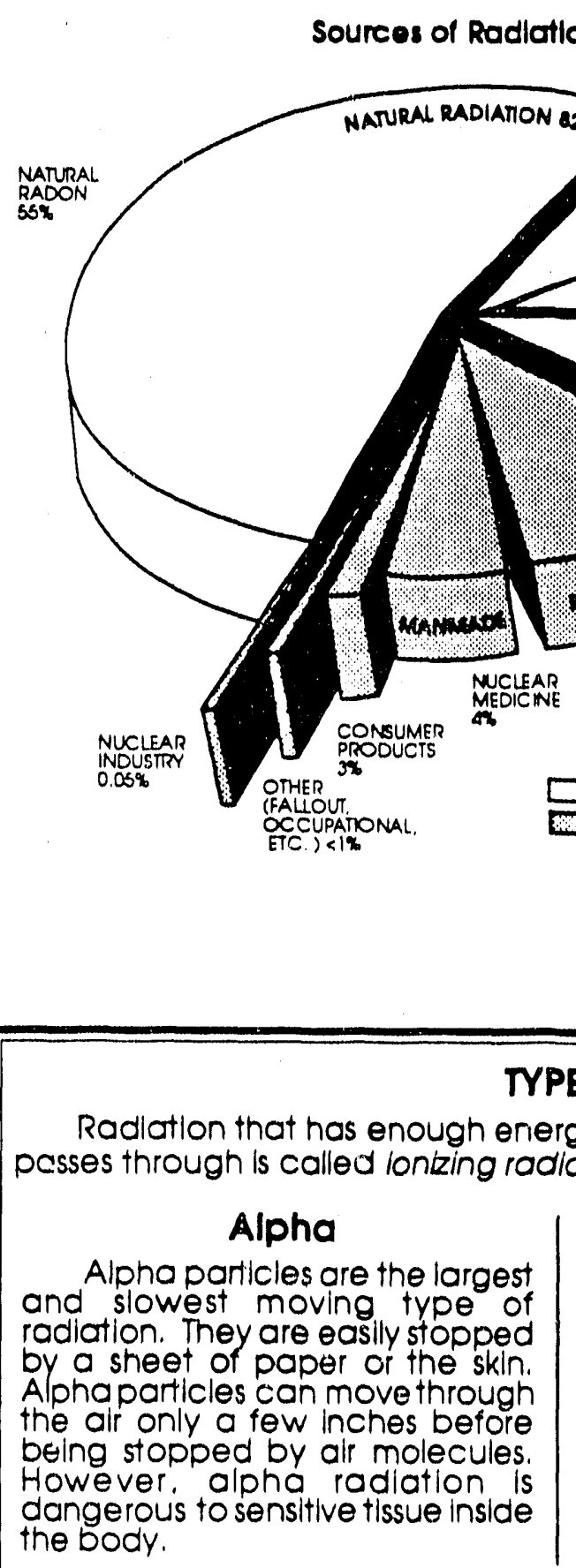

Many materlals-both natural and manmade - that we come into

contact with in our everyday lives

are radloactlve. These materials are composed of atoms that release energetic particles or waves as they change into more stable forms. These particles and waves are referred to as radiation. arid their emission as radioactivity.

As the chart on the left shows, most environmental radlation (82\%) is from natural sources. By far the largest source is radon, an odorless. colorless gas given off by natural radlum in the Earth's crust. While radon has always been present in the environment, its significance is better NATURAL MANMADE understood today. Manmade radlation-mostly from medical Lses and consumer products-adds about eighteen percent to our total exposure.

\section{TYPES OF IONIZING RADIATION}

Radlation that has enough energy to disturb the electrical balance in the atoms of substances it passes through is called lonizing radiation. There are three basic forms of lonking radiation. and slowest moving type of rad ation. They are easly stopped Alphaparticles can move through the air only a few inches before being stopped by air molecules. However, alpha radiation is the body.

\section{Beta}

Beta particles are much smaller and faster moving thar, alpha particles. Beta particles pass through paper and can travel in the air for aboust 10 feet. However, they can be stopped by thin shielding such as a sheet of aluminum foll.

\section{Gamma}

Gamma radiation is a type of electromagnetic wave that travels of the speed of light. it takes a thick shield of steel, lead, or concrete to stop gamma rays. $X$ rays and cosmic rays are similar to gamma radiation. $x$ rays are produced by manmade devices; cosmlc rays reach Earth from outer space. 


\section{Units of Measure}

Radlation can be measured in a variety of ways. Typlcally, units of measure show elther 1) the total amount of radloactlvity present in a substance, or 2) the level of radiation being given off.

The radioactivity of a substance is measured in terms of the number of transformations (changes into more stable forms) per untt of time. The curle is the standard unit for this measurement and is based on the amount of radioactivity contained in 1 gram of radium. Numerically, 1 curle is equal to 37 billion transformations per second. The amounts of radioactivity that people normally work with are in the millicurie (one-thousandth of a curle) or microcurie (one-millionih of a curle) range. Levels of radioactlvity in the environment are in the picocurle, or $\mathrm{pCl}$ (one-trillionth of a curie) range.
Levels of radlation are measured in various units. The level of gamma radiation in the air is measured by the roentgen. This is a relatively large unit, so measurements are often calculated in milliroentgens. Radiation absorbed by humans is measured in either rad or rem. The rem is the most descriptive because it measures the abllity of the specific type of radiation to do damage to blological tissue. Again, typical measuremerts will often be in the millirem (mrem), or one-thousandth of a rem, range.

In the intemational scientific community, absorbed dose and biological exposure are expressed in grays and seiverts. I gray (Gy) equals 100 rad. I selvert (Sv) equals $100 \mathrm{rem}$. On the average. Americans receive about 360 mrem of radiation a year. Most of this (97\%) is from natural radiation and medical exposure. Specific examples of common sources of radiation are shown in the chat below.

\section{Cosmic Radiation}

Cosmic radiation is high-energy garnma radlation that originates in outer space and Afters through our atmosphare.

Sen Level ..............................20 $26 \mathrm{mrem} /$ year

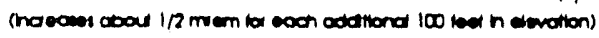
Atlanta, Georgia (1.050 feet)

...........................................31 mrem/Year Denver, Colorado (5.300 feet)

$50 \mathrm{mrem} /$ year Minneapolis. Minnesota (815 feet) $30 \mathrm{mrem} /$ year

Salt Lake City, Utan $(4,400$ tert) $46 \mathrm{mrem} /$ yoar

\section{Terrestrial Radiation}

Terrestrial sources are naturally radiooctive elements in the soll and water such as uranium, rodium, and thorlum. Average levels of these elements are $1 \mathrm{pCl} / \mathrm{gram}$ of soll.

United States (average) ........... $26 \mathrm{mrem} / \mathrm{year}$ Den'ver, Colorado .....................63 $63 \mathrm{mrem} /$ year Nile Delta, Egypt .................... $350 \mathrm{mrem} /$ year Paris, France ......................... $350 \mathrm{mrem} / \mathrm{y} \theta \mathrm{ar}$ Coast of Kerala. India ........... $400 \mathrm{mrem} /$ year McAlpe. Brazl ................... $2.558 \mathrm{mrem} / \mathrm{year}$ Pocos De Caldas, Brod ال.....7.000 mrem/yeat

\section{Buildings}

Many building moterials. especially granite. contain naturally radlocetive elements.

U.S. Capitol Bullding .................. $85 \mathrm{mrem} /$ year Base of Statue of Uberty ........325 miem/year Grand Central Station ..........525 mrem/year The Vatican ...........................800 $\mathrm{mrem} /$ Year Radon

Radion levels in bulldings vary. depending on geographic location. from 0.1 to $200 \mathrm{pCl} / \mathrm{liter}$ Averoge Indoor Radon Level ....... $1.5 \mathrm{pC}$.//liter Occupotional Working Limit..... 100.0 pCl/llter

\section{RADIATION IN THE ENVIRONMENT}

Because the radlocactivity of indluldual samples varles, the numbers glven here are approximate or represent an average. They are shown to provlde a perspective for concentrations and levels of radloactlvity rather than dose.

\section{mrem $=$ millirem} $\mathrm{pCl} \equiv$ picocurle

\section{Food}

Food contibutes an average of 20 miem/year. mostly trom potassium-40. carbon-14, hydrogen-3, radum-226. and thorlum-232.

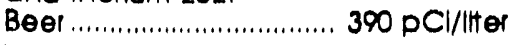
Tap Water ...................... $20 \mathrm{pCl} / \mathrm{llter}$ Milk .............................. 1,400 pCl/llter Salad Oll ........................4,900 pCl/liter Whiskey ........................ 1,200 pCl/liter Brazl Nuts ............................. 14 pCl/g Bananas ............................... $3 \mathrm{pCl} / \mathrm{g}$ Flour ................................ $0.14 \mathrm{pCl} / \mathrm{g}$ Peanuts \& Peanut Butter . $0.12 \mathrm{pCl} / \mathrm{g}$ Tea ................................... $0.40 \mathrm{pCl} / \mathrm{g}$

\section{Medical Treatinent}

The exposures from medical diagnosis vary widely according to the required procedure, the equipment and film used for $x$ iays, and the skill of the operator.

Chest $X$ Ray ......................... 10 mrem

Dental $x$ Ray.Each ............. 100 mrem

\section{Consumer Goods}

Clgarettes-two packs/day

(polonium-210) ......................8,000 miem/year

Color Television ..........................<1 miem/year

Gas Lantern Mantle

(thorlum-232) ................................ $2 \mathrm{mrem} /$ yed

Hlghway Construction .................. 4 mrem/year

Airplane iravel at 39,000 feet

(cosmic) .................................... $5 . \mathrm{mrem} /$ hour

Notural Gas Heating and Cookling

(radon-222) .................................. $2 \mathrm{mrem} /$ Year

Phosphate Fertlizers .....................4 miem/year

\begin{tabular}{|c|c|c|c|}
\hline \multicolumn{4}{|c|}{$\begin{array}{l}\text { Natural Rodloocttvity in Flonda Phosphate } \\
\text { Fertilzers (In pel/aram) }\end{array}$} \\
\hline & Normal & $\mid \begin{array}{l}\text { Commentrated } \\
\text { Superphosphate }\end{array}$ & Grpsum \\
\hline$R a-226$ & 21.3 & 21.0 & 33.0 \\
\hline U.238 & 20.1 & 58.0 & 0.0 \\
\hline$m-230$ & 18.9 & 48.0 & 13.0 \\
\hline$m-232$ & 0.6 & 1.3 & 0.3 \\
\hline
\end{tabular}

Porcelain Dentures

(Uranlum) ......................... $1.500 \mathrm{mrem} /$ year Rodlduminescent Ciock

(promethlum - 147) .................. $<1$ miem/yerd

Srnoke Detector

(americlum-241) ..................0.01 mrem/year

International Nuclear Weapons Test Fallout from pre-1980 atmospheric tests

(average for n U.S. clitizen) ...... I mrem/year

\section{Relerences}

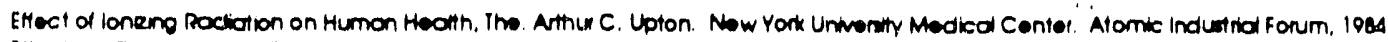

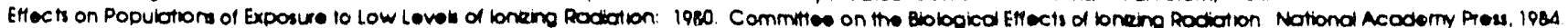

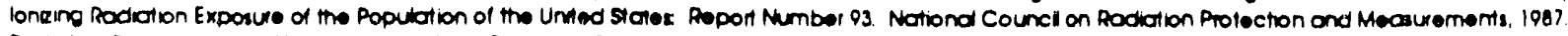

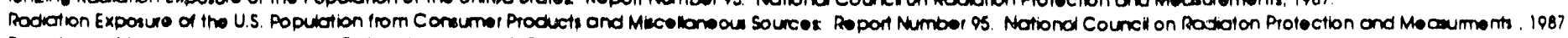

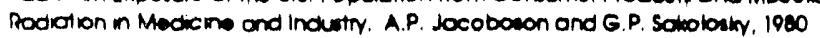

Prodroocivity in Consumer Products. U.S. Nucieor Reoulotory Corrminion. 1978 


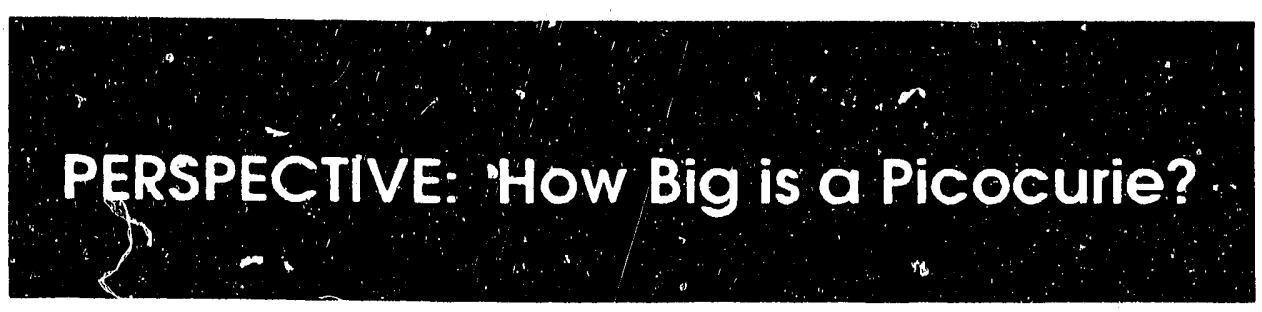

The curie is a standard measure for the intensity of radioactivity contained in a sample of radicactive material. It was named after French scientists Marie and Pierre Curie for their landmark research into the nature of radioactivity.

The basis for the curie is the radic activity of one gram of radium. Radium decays at a rate of about 2.2 trillion disintegrations $\left(2.2 \times 10^{12}\right)$ per minute. A picocurie is one trillionth of a curie. Thus, a picocurie represents 2.2 disintegrations per minute.

To put the relative size of one trillionth into perspective, consider that if the Earth were reduced to one trillionth of its diameter, the "pico earth" would be smaller in diameter than a speck of dust. In fact, it would be six times smaller than the thickness of a human hair.

The difference between the cuile and the picocurie is so vast that other metric units are used between them. These are as follows:

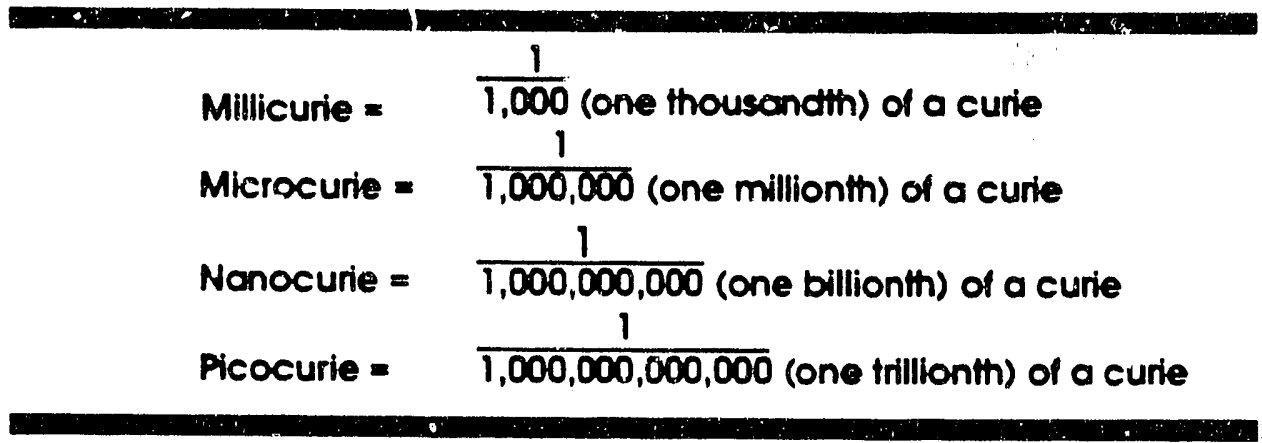

The following chart shows the relative differences between the units and gives analogies in dollars. It also gives examples of where these various amounts of radioactivity could typically be found. The number of disintegrations per minute has been rounded off for the chart.

\begin{tabular}{|c|c|c|c|c|}
\hline $\begin{array}{l}\text { UNIT OF } \\
\text { RADIOACTIVITY }\end{array}$ & SYMBOL & $\begin{array}{l}\text { DISINTEGRATIONS } \\
\text { PER MINUTE }\end{array}$ & $\begin{array}{l}\text { DOLLAR } \\
\text { ANALOGY }\end{array}$ & $\begin{array}{l}\text { EXAMPLES OF } \\
\text { RADIOACTIVE MATERIALS }\end{array}$ \\
\hline 1 Curie & $\mathrm{Ci}$ & $2 \times 10^{12}$ or 2 Tritlion & $\begin{array}{l}2 \text { Times the Annual } \\
\text { Federal Budget }\end{array}$ & $\begin{array}{l}\text { Nuclear Medicine } \\
\text { Generator }\end{array}$ \\
\hline I Millicurie & $\mathrm{mCi}$ & $2 \times 10^{\circ}$ or 2 Billion & $\begin{array}{l}\text { Cost of a New Interstate } \\
\text { Highway from Atlanta to } \\
\text { San Francisco }\end{array}$ & $\begin{array}{l}\text { Amount Used for a Brain } \\
\text { or Liver Scan }\end{array}$ \\
\hline 1 Microcurie & $\mu \mathrm{Ci}$ & $2 \times 10^{6}$ or 2 Million & $\begin{array}{l}\text { All-Star Baseball Player's } \\
\text { Salary }\end{array}$ & $\begin{array}{l}\text { Amount ilsed in Thyroid } \\
\text { Tests }\end{array}$ \\
\hline I Nanocurie & $\mathrm{nCi}$ & $2 \times 10^{3}$ or 2 Thousand & $\begin{array}{l}\text { Annual Home Energy } \\
\text { Costs }\end{array}$ & Consumer Prisducts \\
\hline 1 Picocurie & $\mathrm{pCi}$ & 2 & $\begin{array}{l}\text { Cost of a Hamburger and } \\
\text { Coke }\end{array}$ & $\begin{array}{l}\text { Background Environmental } \\
\text { Levels }\end{array}$ \\
\hline
\end{tabular}




\section{PERSPECTIVE: Radioactivity in Gas Lantern Mantles}

\section{Around the House}

Many household products contain a small amount of radioactivity. Examples include gas lantern mantles, smoke detectors, dentures,

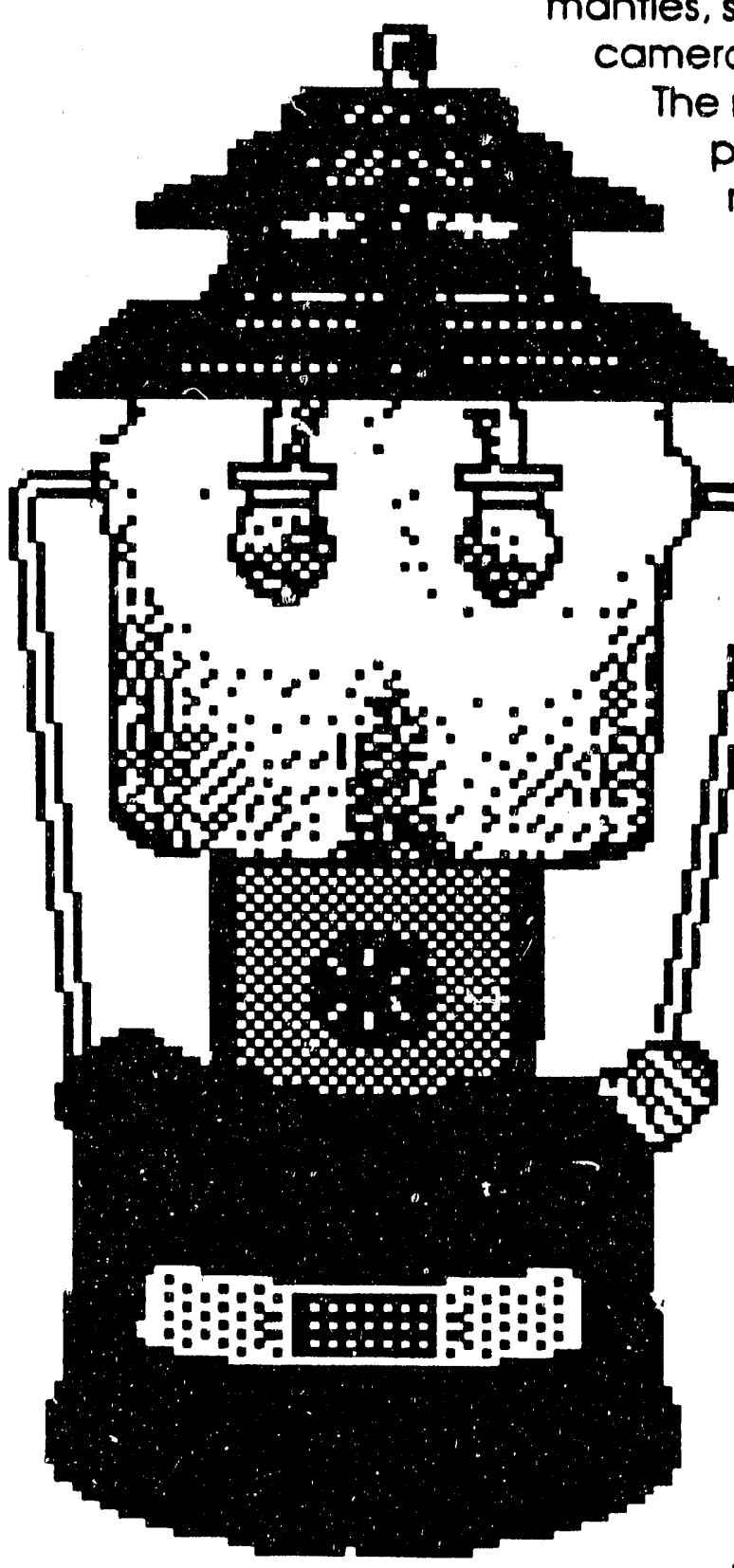

The radiosctivity is added to the products either specifically to make them work, or as a result of using compounts of elements like thorium and uranium in producing them. The amount of radiation the products gives off is not considered significant. But with today'; sensitive equipment, it can be detected.

\section{Lanterns: In a New Light}

About 20 million gas lantern mantles are used by campers each year in the United States.

under today's standards, the amoui :! of natural radioactivity found in a lantern mantle would require precautions in handling it at many Government or industry sites. The radioactivity present would contaminate 15 pounds of ditt to abo: a allowable levels. Th, is is because the average montle contains $1 / 3$ of a gram of thorium oxide. which has a specific activity ( a measure of radioactivity) of approximately 100,000 picocuries per gram. The approximately 35,000 picocuries of radioactivity in the mantle would, if thrown onto the ground, be considered low-level radioactive contamination. 


$$
-
$$


(1)

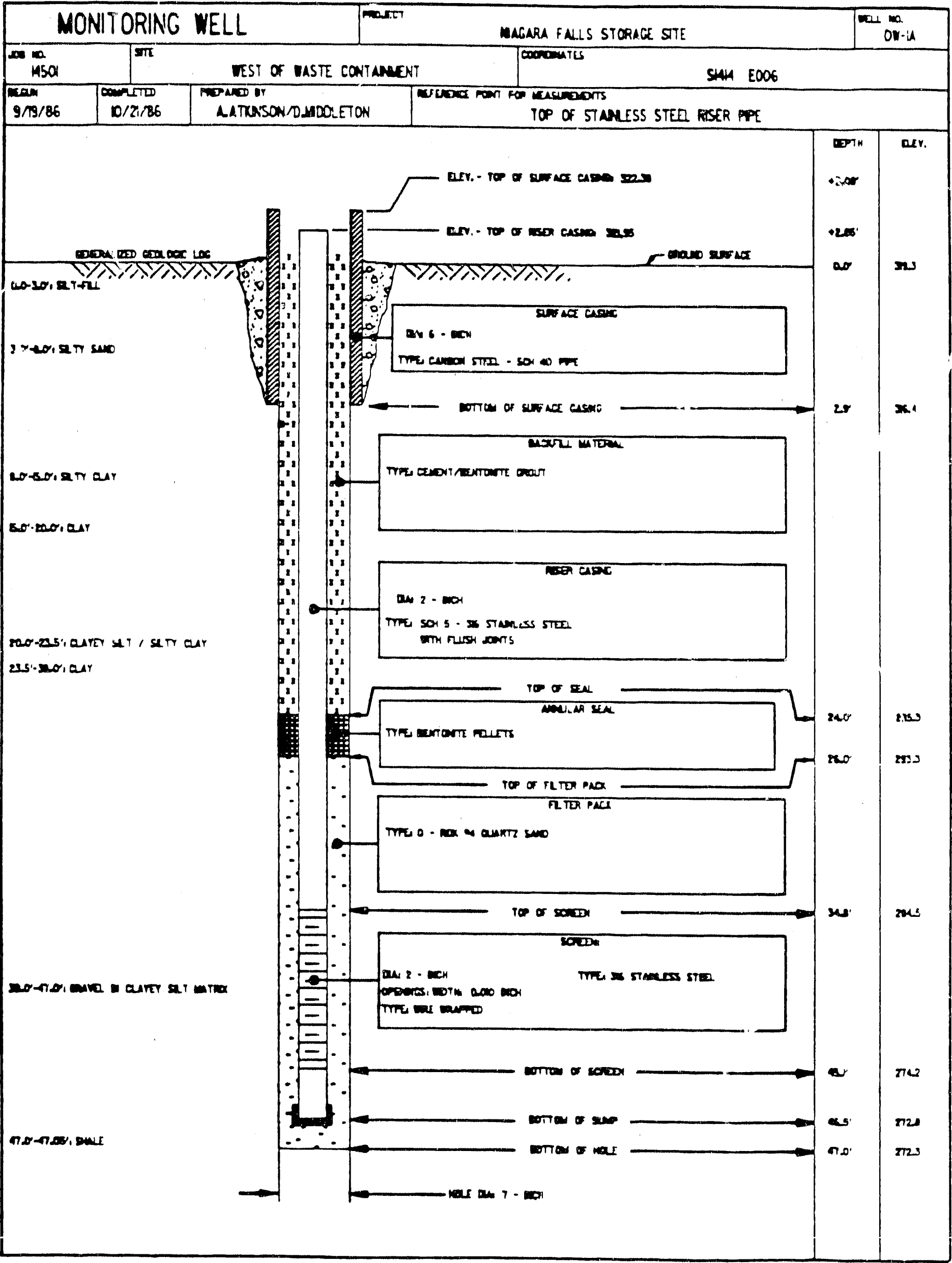




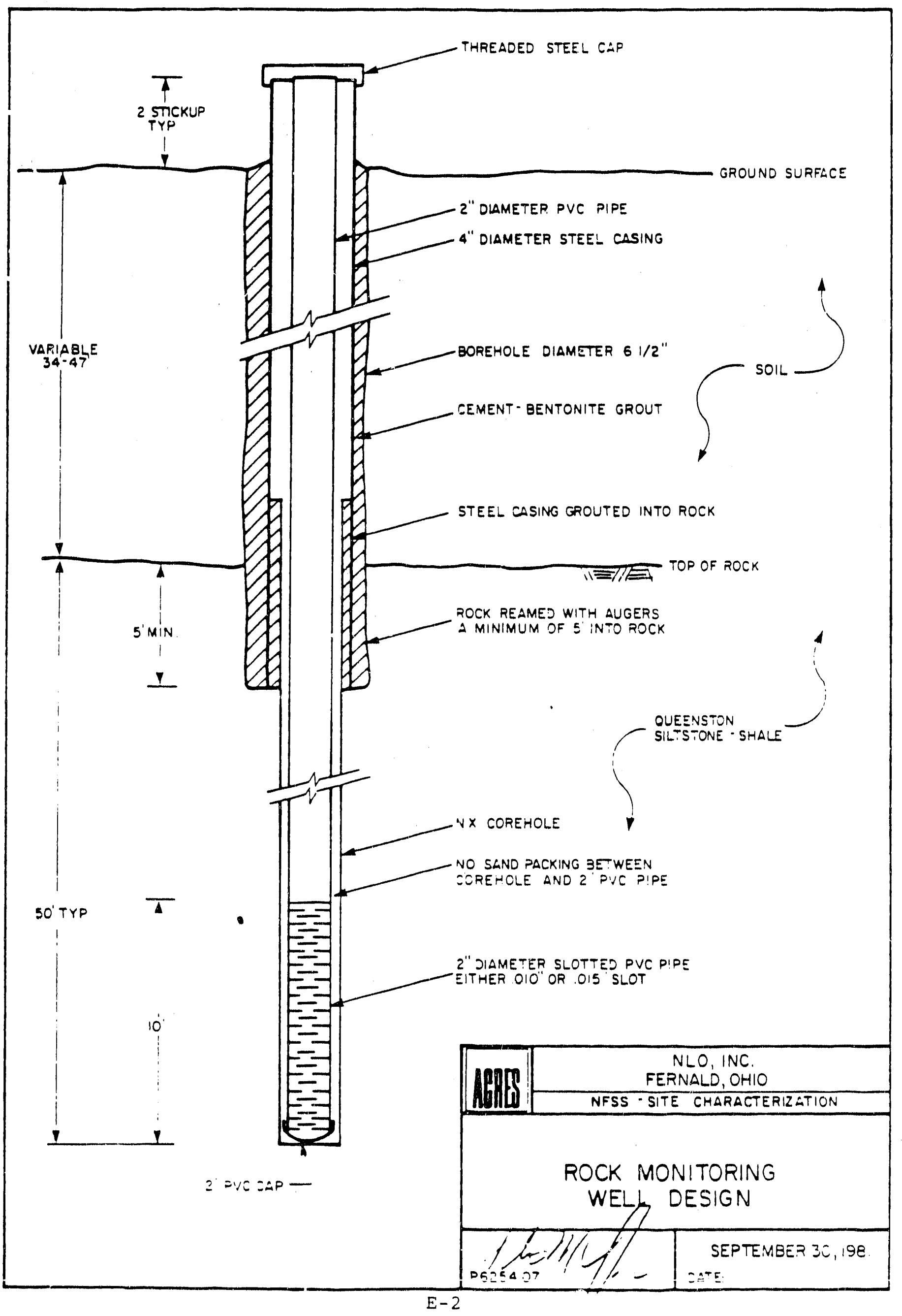




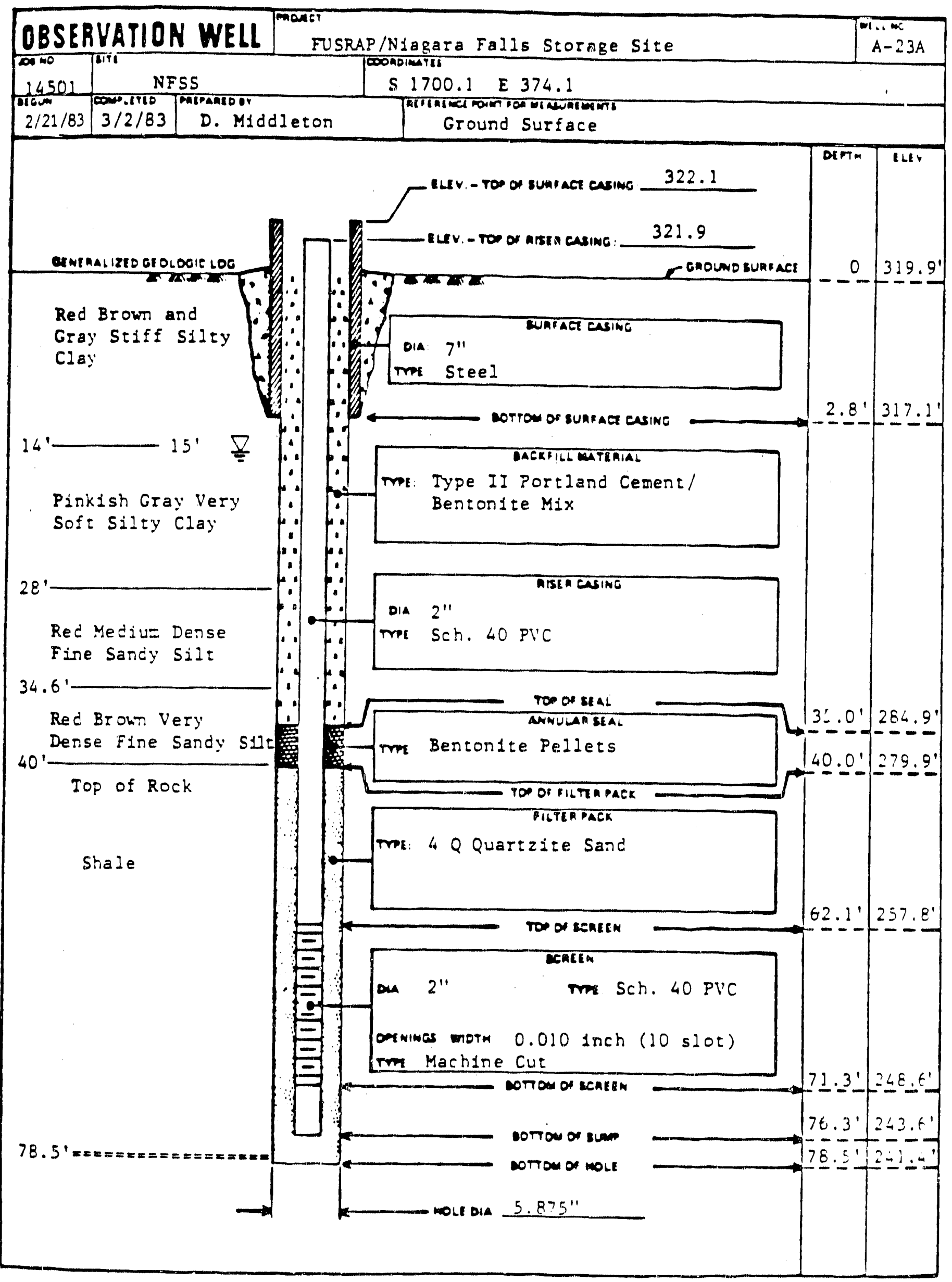



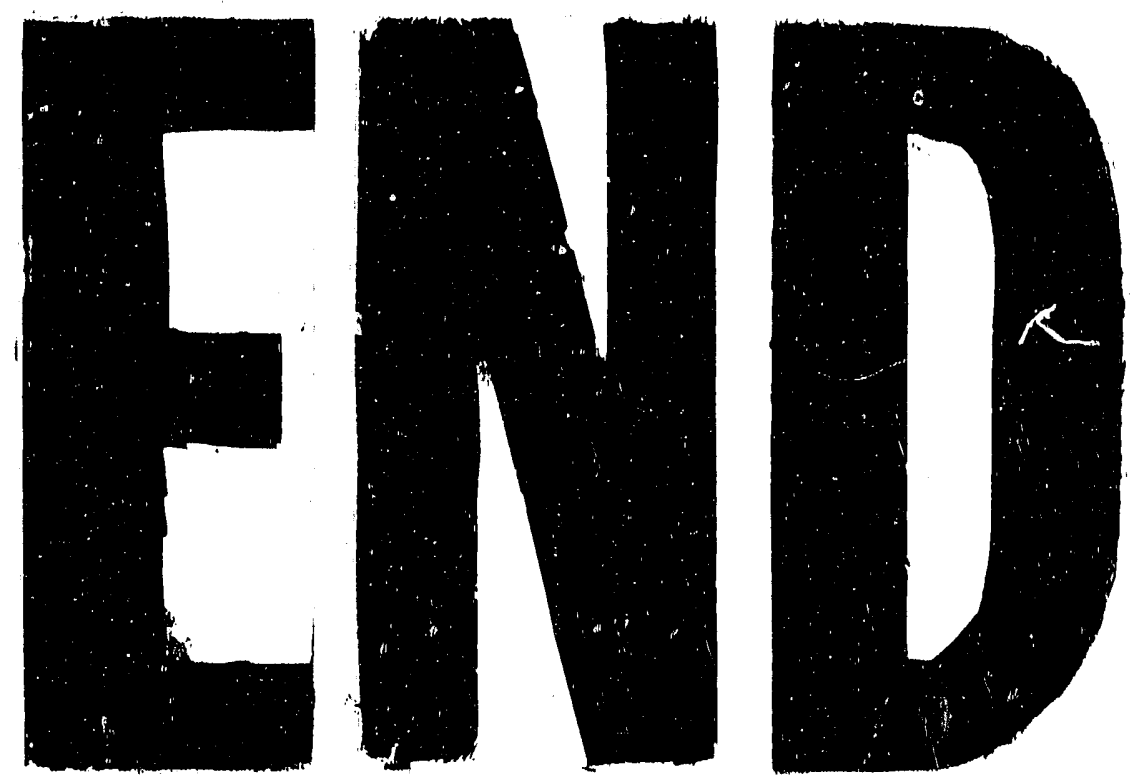

5
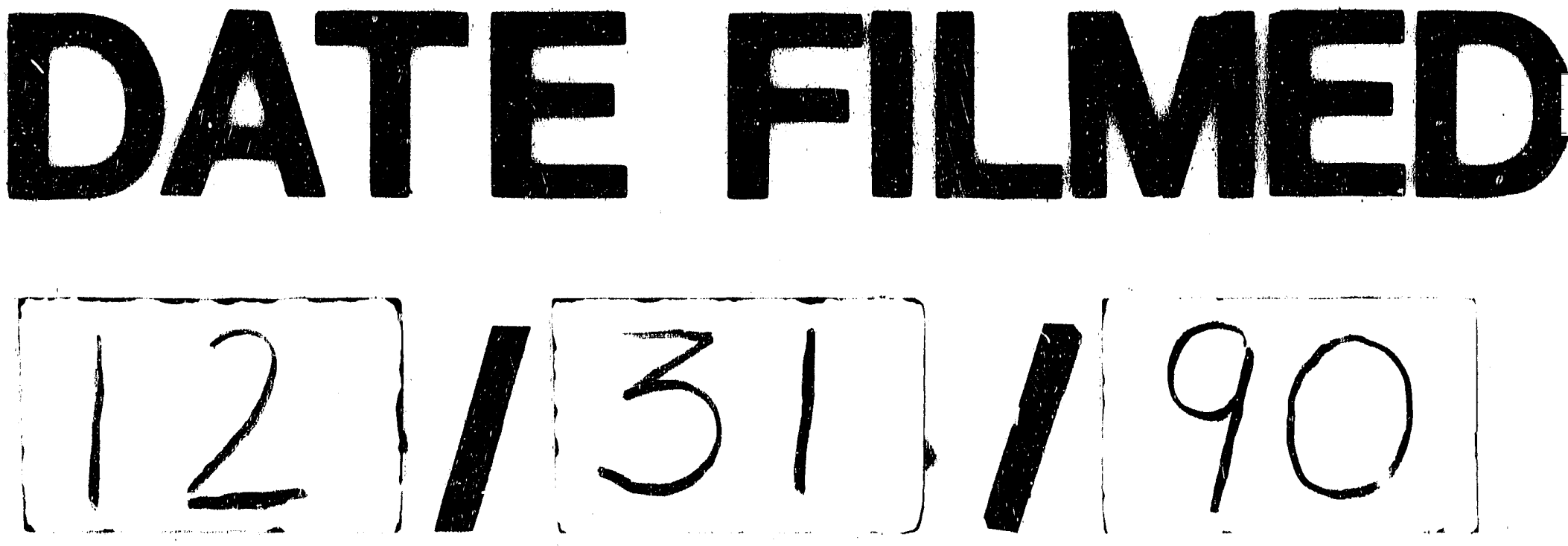
